\title{
Effects of nitrogen and cutting management on root growth and productivity of a Kentucky bluegrass (Poa pratensis L.) and white clover (Trifolium repens L.) pasture
}

\author{
Gina Marie Kertulis \\ West Virginia University
}

Follow this and additional works at: https://researchrepository.wvu.edu/etd

\section{Recommended Citation}

Kertulis, Gina Marie, "Effects of nitrogen and cutting management on root growth and productivity of a Kentucky bluegrass (Poa pratensis L.) and white clover (Trifolium repens L.) pasture" (2001). Graduate Theses, Dissertations, and Problem Reports. 1257.

https://researchrepository.wvu.edu/etd/1257

This Thesis is protected by copyright and/or related rights. It has been brought to you by the The Research Repository @ WVU with permission from the rights-holder(s). You are free to use this Thesis in any way that is permitted by the copyright and related rights legislation that applies to your use. For other uses you must obtain permission from the rights-holder(s) directly, unless additional rights are indicated by a Creative Commons license in the record and/ or on the work itself. This Thesis has been accepted for inclusion in WVU Graduate Theses, Dissertations, and Problem Reports collection by an authorized administrator of The Research Repository @ WVU. For more information, please contact researchrepository@mail.wvu.edu. 
Effects of Nitrogen and Cutting Management on Root Growth and Productivity of A Kentucky Bluegrass (Poa pratensis L.) and White Clover (Trifolium repens L.)

Pasture

\title{
Gina Marie Kertulis
}

Thesis submitted to the College of Agriculture, Forestry and Consumer Sciences at West Virginia University in partial fulfillment of the requirements for the degree of

\author{
Master of Science \\ In \\ Plant and Soil Sciences
}

\author{
William B. Bryan, Ph.D., Chair \\ Louis M. McDonald, Jr., Ph.D. \\ Edward B. Rayburn, Ph.D. \\ Division of Plant and Soil Sciences
}

\author{
Morgantown, West Virginia \\ 2001
}

Keywords: Pasture quality, Root volume, Root dry weight, Root length, Soil nitrate Copyright 2001 Gina Marie Kertulis 


\section{ABSTRACT \\ Effects of Nitrogen and Cutting Management on Root Growth and Productivity of A Kentucky Bluegrass (Poa pratensis L.) and White Clover (Trifolium repens L.) Pasture}

\section{Gina Marie Kertulis}

Nitrogen $(\mathrm{N})$ and defoliation effects on productivity, root growth and soil nitrate $\left(\mathrm{NO}_{3}{ }^{-}\right)$ in a Kentucky bluegrass and white clover pasture were examined. Nitrogen was applied annually in two equally split applications at rates of 0,80 or $160 \mathrm{~kg} \mathrm{~N} \mathrm{ha}^{-1}$. After reaching $12.7 \mathrm{~cm}$, plants were cut to $2.5,5.1$ or $7.6 \mathrm{~cm}$. Herbage was analyzed for yield, crude protein $(\mathrm{CP})$, neutral detergent fiber and acid detergent fiber. Root samples were divided into three depths: $0.0-5.1,5.1-10.2$ and $10.2-20.3 \mathrm{~cm}$, and analyzed for volume, dry weight and length. Soil $\mathrm{NO}_{3}{ }^{-}$was measured. At the $2.5 \mathrm{~cm}$ cut yield and fiber concentrations were higher; $\mathrm{CP}$ concentration was lower. Roots in the top depth had lower volume, dry weight and length. When no $\mathrm{N}$ was added, $\mathrm{CP}$ concentration of herbage and soil $\mathrm{NO}_{3}{ }^{-}$concentration were lower, and root volume and dry weight were lower in the $0.0-5.1 \mathrm{~cm}$ depth. Cutting to $2.5 \mathrm{~cm}$ stopped root growth; more herbage was harvested but the material was more mature, decreasing $\mathrm{CP}$ and increasing fiber. 


\section{ACKNOWLEDGEMENTS}

I wish to sincerely thank my advisor, Dr. William Bryan, for his support, encouragement and patience throughout this study. All he has taught me during my experience as a Masters student at WVU has been invaluable. I wish to express my gratitude to my committee members, Dr. Louis McDonald and Dr. Edward Rayburn. They have been long on enthusiasm and have always happily shared their advice.

Sincere gratitude is due to Kenneth Tartar. His understanding and patience were greatly needed and much appreciated, and his support made a challenging task more manageable.

Most importantly, I dedicate this study to my parents, Anthony and Barbara Kertulis. All I have accomplished is a result of their love and support. They have enthusiastically encouraged all of my endeavors, and I do not think I could adequately express my gratitude for everything they have done. 


\section{TABLE OF CONTENTS}

Page

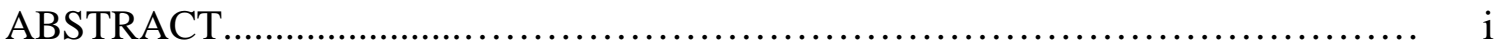

ACKNOWLEDGEMENTS .................................................... iii

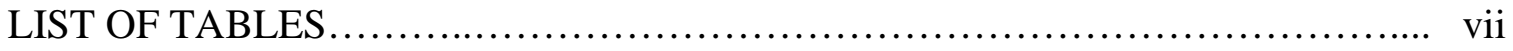

LIST OF FIGURES...................................................................... vii

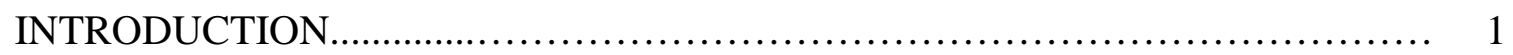

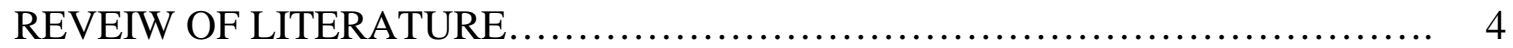

Grass and Legume Pasture Production........................................... 4

Effects of defoliation on pasture plants.................................................... 4

Effects of frequency and intensity of defoliation......................................... 6

Forage quality and animal performance...................................................... 7

Root Characteristics of Pasture Grasses and Legumes............................................. 8

Effects of defoliation on roots................................................................ 9

Effects of nitrogen on root growth........................................................ 10

Root distribution and water uptake....................................................... 11

Acquisition and uptake of nutrients by roots............................................. 12

Root competition.................................................................... 13

Nitrogen and Pasture Production....................................................................... 14

Legumes as a source of nitrogen for pastures.......................................... 15

Addition of nitrogen fertilizer to pastures.................................................. 17

Effect of nitrogen fertilizer on legume populations.................................... 19

Legumes versus nitrogen fertilizers for pastures........................................ 19

Timing of nitrogen applications............................................................. 21

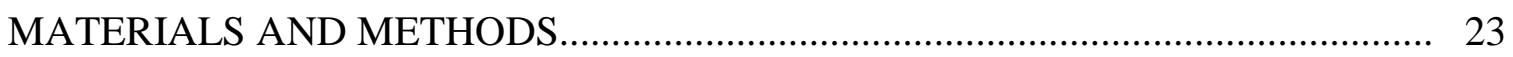

Experimental Treatments and Design.................................................................. 23

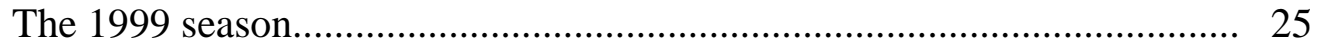

The 2000 season........................................................................ 26

Pasture Production and Quality.................................................................... 27

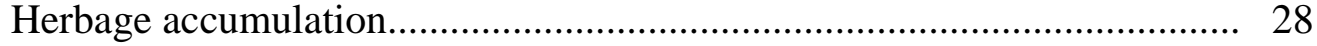

Total Kjeldahl nitrogen...................................................................... 28 
Neutral detergent fiber and acid detergent fiber....................................... 28

Pasture Root Growth................................................................................... 29

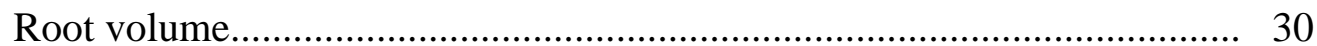

Root length.................................................................................. 30

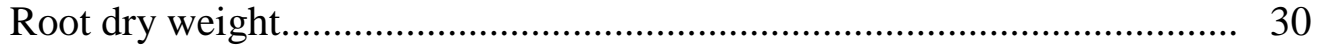

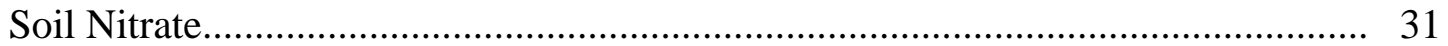

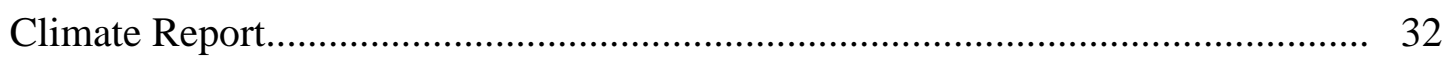

Statistical Analysis.................................................................................... 32

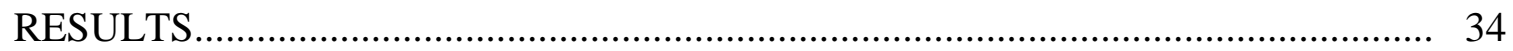

Pasture Production and Quality.................................................................... 34

Herbage accumulation....................................................................... 34

Crude protein concentration............................................................ 36

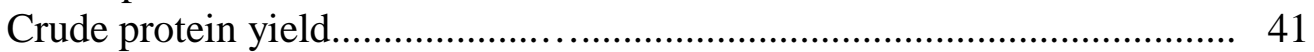

Neutral detergent fiber..................................................................... 42

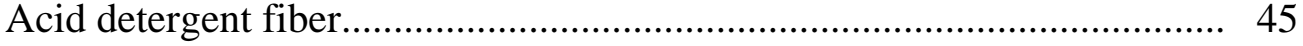

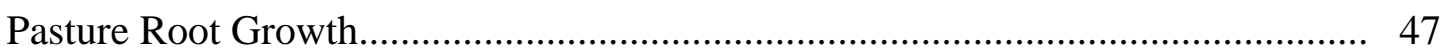

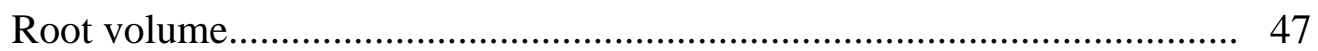

Root dry weight........................................................................... 51

Root length................................................................................ 54

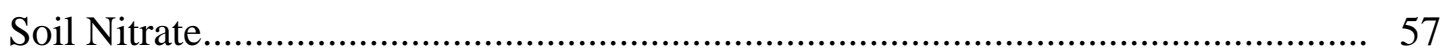

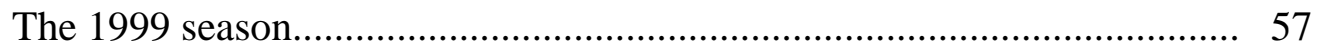

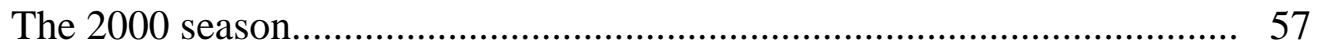

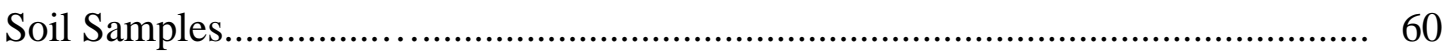

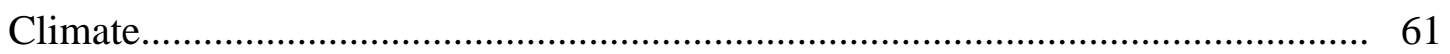

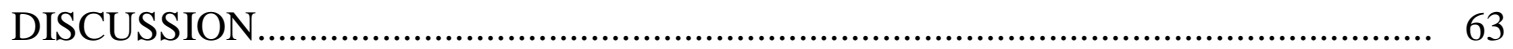

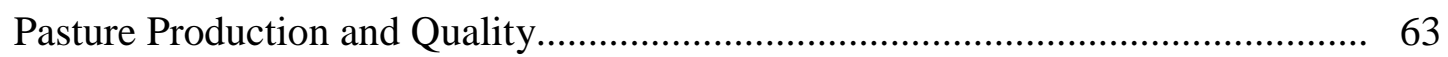

Effects of nitrogen fertilizer..................................................................... 63

Effects of cutting management.............................................................. 66

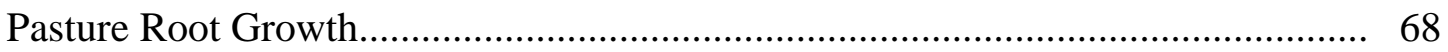

Effects of nitrogen fertilizer.................................................................. 70

Effects of cutting management.............................................................. 71

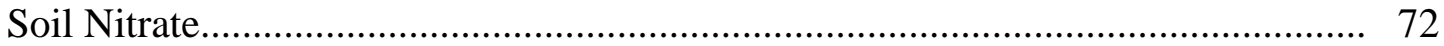


Effects of nitrogen fertilizer......................................................... 72

Effects of cutting management.......................................................... 73

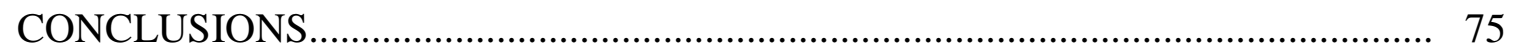

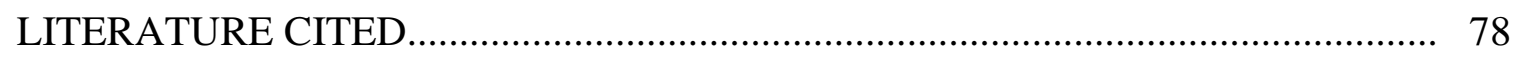

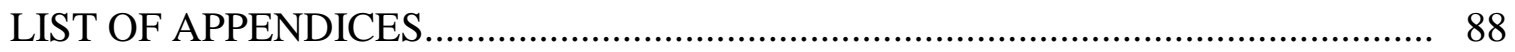

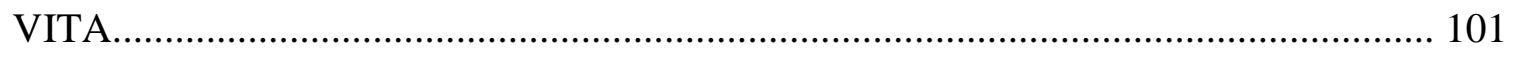




\section{LIST OF TABLES}

Table

Page

1. Experimental treatments and treatment abbreviations................................ 24

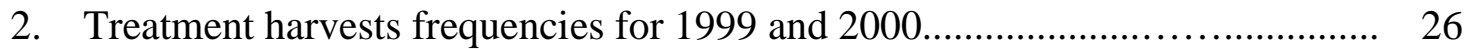

3. Harvest period designations for harvest cutting dates in 1999 and $2000 \ldots \ldots \ldots . .27$

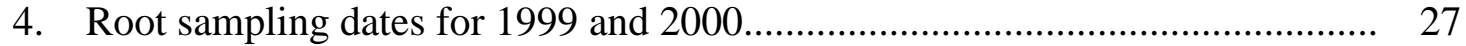

5. Effect of $\mathrm{N}$ treatment, cutting management and year on annual herbage accumulation and CP yield.................................................................... 35

6. Effect of $\mathrm{N}$ application, cutting management, harvest period and year on $\mathrm{CP}$, NDF and ADF concentrations in herbage.................................................. 37

7. Effect of depth, $\mathrm{N}$ treatment, cutting management and sampling date on root volume.

8. Effect of depth, $\mathrm{N}$ treatment, cutting management and sampling date on root dry weight

9. Effect of depth, $\mathrm{N}$ treatment, cutting management and sampling date on root length.

10. Effect of $\mathrm{N}$ treatment, cutting management and $\mathrm{N}$ application date on soil nitrate concentrations in 1999 and 2000

11. Effect of $\mathrm{N}$ treatment, cutting management and year on $\mathrm{pH}$ and available $\mathrm{P}, \mathrm{K}, \mathrm{Ca}$ and $\mathrm{Mg}$ of soil. 


\section{LIST OF FIGURES}

Figure

Page

1. Experimental plot layout indicating the designated sampling areas................. 24

2. Effect of year and cutting management on annual herbage accumulation......... 34

3. Effect of year and $\mathrm{N}$ treatment on $\mathrm{CP}$ concentration in herbage...................... 38

4. Effect of $\mathrm{N}$ treatment, cutting management and year on $\mathrm{CP}$ concentration in herbage.

5. Effect of harvest period and $\mathrm{N}$ treatment on $\mathrm{CP}$ concentration in herbage harvested in 2000 .

6. Effect of year and cutting management on $\mathrm{CP}$ concentration in herbage........... 40

7. Effect of harvest period and cutting management on the $\mathrm{CP}$ concentration in herbage harvested in 2000 .

8. Effect of year and $\mathrm{N}$ treatment on $\mathrm{CP}$ yield....................................... 42

9. Effect of harvest period and cutting management on NDF concentration in herbage harvested in 2000 .

10. Effect of year and cutting management on NDF concentration in herbage.

11. Effect of year and $\mathrm{N}$ treatment on ADF concentration in herbage.............. 46

12. Effect of year and cutting management on ADF concentration in herbage

13. Effect of harvest period and cutting management on ADF concentration in herbage harvested in 2000 .

14. Effect of depth and $\mathrm{N}$ application on root volume

15. Effect of depth and cutting management on root volume

16. Effect of depth and $\mathrm{N}$ treatment on root dry weight.

17. Effect of depth and cutting management on root dry weight 
18. Effect of depth and cutting management on root length............................... 56

19. Effect of $\mathrm{N}$ treatment, cutting management and sampling date on soil $\mathrm{NO}_{3}{ }^{-}$concentration in 2000 ...

20. Average monthly temperature from March to October 1999 and 2000, as recorded at Morgantown Municipal Airport.................................................

21. Total monthly rainfall from March to October 1999 and 2000, as recorded at Morgantown Municipal Airport. 


\section{INTRODUCTION}

The terrain that is commonly found throughout much of West Virginia is steep and mountainous. Therefore, many areas in the state are unsuitable for crop cultivation. However, permanent pastures may be a suitable and beneficial alternative agricultural land use. Pasture plants can provide soil erosion control on the steep hillsides, and the pastures, in general, can provide an economical and high quality diet for a variety of grazing animals.

In pastures in West Virginia, Kentucky bluegrass (Poa pratensis L.) and white clover (Trifolium repens L.) are considered two of the most desirable species. Both are commonly found in many of West Virginia's permanent pastures (Pierre et al., 1937). Kentucky bluegrass and white clover compliment the growth characteristics of each other and generally produce high-quality forage.

Kentucky bluegrass is an extremely palatable, cool-season grass. It is a long-lived perennial that forms a dense sod and propagates via seeds and rhizomes. It is commonly found in the northeastern and north central regions of the United States. Kentucky bluegrass is widely used because it is tolerant to high frequency and high intensity grazing and cutting; however, it is not very tolerant of high temperatures. Since Kentucky bluegrass is a cool season species it produces most of its forage by the middle of June.

White clover is a low-growing perennial legume. As opposed to Kentucky bluegrass, white clover is a short-lived species. It is valued not only for its nitrogen contributions, but for the high forage quality it produces when grown in pastures with 
grasses. White clover spreads by stolons and has a rather shallow root system. Because of its shallow root system, white clover does not persist well in droughty soils. However, it is tolerant of close and frequent grazing.

In the northeastern United States, pasture production is often seriously restricted by a lack of available nitrogen (Robinson and Sprague, 1946). Nitrogen (N) deficiency in forage may reduce photosynthesis, plant growth, cell size, and protein content. Reduced crude protein is the main effect of N stress on pasture quality (Sanderson et al., 1997). The incorporation of legumes, such as white clover, into pastures is an economical method for adding nitrogen. Legumes contribute nitrogen below ground by the decay of nodules, legume root exudation, and/or a mycorrhizal fungal link between legume and grass roots (Laidlaw et al., 1996). However, white clover populations in pastures often fluctuate, and consequently its contribution of $\mathrm{N}$.

Much less research has been conducted on the below ground growth of pastures. However, root growth and function are vital to the productivity and success of any plant or plant system. Roots are not simply important for their role in absorbing the necessary nutrients and water for plant survival. They may be essential for energy storage, necessary for regrowth of herbage after defoliation, and survival of the plant through the winter or drought. Root production is depends on several factors, including: genetics, environment and competition. Root competition among grass seedlings begins earlier and has a much greater impact on the overall plant production than does shoot competition. Also, root density and distribution in the soil are considered the main factors determining below ground competition (Nie et al., 1997). 
This study was conducted to investigate the effects of varying $\mathrm{N}$ application rates and cutting management on a permanent Kentucky bluegrass and white clover pasture. The effects of the treatments on forage production and quality, root growth, and soil nitrate $\left(\mathrm{NO}_{3}^{-}\right)$were examined.

The objectives of this study were:

1. To examine the effects of three $\mathrm{N}$ applications and three clipping managements on the crude protein and fiber content of the forage in a Kentucky bluegrass and white clover pasture.

2. To examine the effects of three $\mathrm{N}$ application levels and three cutting managements on root volume, root dry weight and root length, of the pasture.

3. To examine the effects of three $\mathrm{N}$ application rates to pasture on the levels of $\mathrm{NO}_{3}{ }^{-}$in the soil. 


\section{REVIEW OF LITERATURE}

\section{Grass and Legume Pasture Production}

Proper pasture management is vital to ensure maximum production by the pasture plants as well as by the grazing animal. Several factors should be taken into consideration when managing a pasture. Some of the most important factors include: the type of plants grown in the pasture, time of year, frequency and intensity of defoliation, type of grazing animals employed, and fertilizer, if any, used on the pasture.

Each of the factors listed can influence rate of recovery after defoliation and forage quality. Pastures consisting of cool season grasses have a flush of growth in the spring season (caused by good growing conditions and the cool-season grasses entering their reproductive growth stage), a decline of growth in mid-summer, and a slight increase in production in late-summer/early-fall. Managing the frequency and intensity of defoliation is important to best utilize the abundant dry matter produced during the spring flush. For example, Williams and Hammond (1999) suggested that the pasture acreage should be divided: part used for "continuous intensive stocking" and the rest used for hay production. Management is also important during mid-summer, when growth rate is low, to avoid overgrazing and to ensure adequate availability and regrowth.

\section{Effects of defoliation on pasture plants}

Defoliation, the removal of aboveground portions of a plant, can have different effects on the entire plant and its physiology. A plant's reaction to defoliation depends on the amount, age, rate of removal, and type of herbage removed; the plant's environment and time of year affect a plant's reaction to defoliation (Richards, 1993). 
Generally, removal of old leaves affects a plant less than the removal of younger leaves, because older leaves are often shaded and tend to have lower photosynthetic potential (Gold and Caldwell, 1989). Also, removal of meristematic tissue, important in the production of new cells, is more detrimental to plant growth than removal of leaf tissue (Richards, 1993).

Once defoliation occurs, photosynthesis is reduced (Richards, 1993), and the plant uses its carbohydrate reserves to replace lost photosynthetic tissue (Weaver, 1930). The reduction in photosynthetic capacity affects the entire plant almost immediately. The amount of herbage removed does not necessarily correlate directly with the reduction in photosynthetic capacity of the plant. Remaining leaves (often older) have less photosynthetic capability (Richards, 1993). Remaining leaves may also experience photosynthetic rate reduction. On a defoliated alfalfa (Medicago sativa L.) plant undamaged leaves were found to have a 4 - $20 \%$ lower net photosynthetic rate compared to leaves on plants that were not defoliated (Hodgkinson et al., 1972; Hodgkinson, 1974).

To recover from defoliation, a plant will reallocate its resources. Photosynthate supply to roots is reduced, and the allocation of photosynthate to shoot meristems is reduced (Richards, 1993). There is an almost immediate increase in the exportation of fixed carbon from leaves that are photosynthetically active to actively growing shoots (Haratt et al., 1964; Marshall and Sagar, 1965; Ryle and Powell, 1975; Bassman and Dickmann, 1985). Also, N may be reallocated quickly within shoots. Ourry et al. (1988) found that $\mathrm{N}$ previously taken up by perennial ryegrass (Lolium perenne $\mathrm{L}$.) was partitioned to regrowing leaves within 2 days after defoliation. About $80 \%$ of this $\mathrm{N}$ was from the remaining shoots, and the root system supplied the other $20 \%$. 


\section{Effects of frequency and intensity of defoliation}

The frequency and intensity with which a pasture is grazed affect the quantity and quality of the forage consumed by the animal, the amount of time needed for plant recovery, as well as persistence of the plants. Generally, as defoliation frequency decreases, herbage accumulation increases. Grazing height and time of year are also important. Dovel (1996) found that although lower clipping heights increased herbage mass in a wetland meadow, it had less of an effect than date of defoliation. Defoliating the stand to a height of $5 \mathrm{~cm}$ resulted in the highest yield, regrowth, and quality of the forage. In addition, the vigor and persistence of the stand were not visibly reduced by the lower clipping rate. In another study, Mortimer and Ahlgren (1936) found evidence to suggest that Kentucky bluegrass cut to ground level when 4 to 5 in tall, consistently yielded more than a 4 to 5 in stand defoliated to 1.5 in. Similarly, Graber (1933) found that, with abundant $\mathrm{N}$ fertilization, Kentucky bluegrass clipped to 0.5 in 13 times during the season yield $54 \%$ more dry matter than Kentucky bluegrass cut 13 times to $1.5 \mathrm{in}$.

Rotational and continuous grazing management may be compared in order to illustrate differences between pasture managements. Rotational grazing involves subdividing a pasture into paddocks. Animals are moved from paddock to paddock as time and/or pasture production dictates. Rotational grazing is considered to be a more intensive management and usually results in more uniform grazing. It may also reduce grazing selectivity by the animals. Continuous grazing management allows animals to graze the entire pasture continuously during the season. This allows the grazing animal to be more selective, and, depending on the number of animals, may be a less intensive management. Paine et al. (1999) examined growth and quality of rotational and 
continuously grazed pastures. It was found that rotationally grazed pastures produced $1763 \mathrm{lb}$ of wet herbage mass per acre per week, as compared to $850 \mathrm{lb}$ herbage mass per acre per week produced by the continuously grazed pastures. The seasonal means of forage quality indicators, crude protein $(\mathrm{CP})$, neutral detergent fiber (NDF) and acid detergent fiber (ADF) were not significantly different between the two managements. However, the authors stated that rotationally grazed pastures provided forage that was higher in quality for the majority of the grazing season.

\section{Forage quality and animal performance}

Forage quality is an important factor affecting animal performance. Crude protein, NDF and ADF are often used as indicators of forage quality. Dovel (1996) examined the effects of clipping management on the yield and quality of three wetland meadows consisting of mixed forage species. Harvests were made three times during each growing season, and forage samples were analyzed for $\mathrm{CP}$ and $\mathrm{ADF}$. Percent ADF in the bluegrass (Poa spp.) and clover (Trifolium spp.) associations were not affected by cutting height; however, percent ADF for the association did increase with harvest dates. Both harvest date and cutting height affected the crude protein content of the forage. Crude protein concentrations in the bluegrass-clover associations were inversely proportional to clipping heights. Dovel felt that the increasing $\mathrm{CP}$ at lower clipping heights could be explained by increased clover percentages at those heights. An increase in $\mathrm{CP}$ concentration was seen between the first and second harvest dates. Following a decrease in concentration between the second and third dates the $\mathrm{CP}$ concentration in Kentucky bluegrass was found to decline curvilinearly over the growing season (Mason and Lachance, 1983). When a bermudagrass (Cynadon dactylon L.) and white clover 
pasture was compared to a bremudagrass pasture fertilized with $224 \mathrm{~kg} \mathrm{~N} \mathrm{ha}^{-1} \mathrm{yr}^{-1}$, it was found that the grass and legume mixture had a higher $\mathrm{CP}$ concentration. Also, the amount of grass-legume pasture consumed by grazing steers was $27 \%$ greater than the amount of the $\mathrm{N}$-fertilized pasture consumed, and gain per steer was significantly higher (McLaren et al., 1983).

A decrease in forage digestibility often results in reduced live weight gain (LWG) of animals. Generally, dry matter digestibility and total digestible nutrients of most forages vary inversely with lignin content (Forbes and Garrigus, 1948). Knox et al. (1958) found that clipping frequency did not affect lignin content of grass fertilized at a rate of $100 \mathrm{lb} \mathrm{N} \mathrm{ac}^{-1}$ or less. However, at higher $\mathrm{N}$ fertilization rates lignin content increased as the grass aged. A study on digestibility of bermudagrass showed that average dry matter digestibility decreased in mid-summer compared to spring and fall months. In addition, daily gains of grazing steers decreased during the summer months compared to spring and autumn (Webster et al., 1965). This agrees with an earlier finding, by Elder and Murphy in 1961, that seventy percent of the weight gained by steers grazing bermudagrass pasture takes place before July 1.

\section{Root Characteristics of Pasture Grasses and Legumes}

Plant roots, although often ignored, are vital to plant survival. The roots of pasture plants are not as well studied as their aboveground counterparts. Root growth varies depending on species. Often, the main root of legumes generally endures for the life of the plant; however, lateral roots are usually "short-lived" (Lyr and Hoffman, 1967; Kolesnikov, 1971). Grasses do not have main roots but have fibrous root systems. Root 
growth, as with plant growth in its entirety, is a result of both genetic makeup and

environmental factors. Species, changes in hormone distribution (Lamond et al., 1983), availability of water and nutrients (Vogt et al., 1993), and soil conditions can influence structural and physiological development of root systems.

The relationships between plant roots and the soil are important. Soil conditions must allow for adequate uptake of water and nutrients to meet the needs of the plant. Also, structure and permeability of soil, soil organic matter (OM), and soil conservation are directly affected by plant root distribution and density (Gist and Smith, 1948). Plant root distribution in the soil is a result of interactions between the genetic make-up of a plant and environmental factors (Moore and Rhoades, 1966). Root distribution affects water and nutrient uptake efficiency. Root competition, grazing management, nutrient status, various environmental stresses, and plant species are only a few of the factors that influence root growth in a pasture system.

\section{Effects of defoliation on roots}

Defoliation may have several adverse effects on roots. Soon after a plant is defoliated root growth stops, and although the lifespan of roots is variable, many fine roots may die (Luo et al., 1995; Jarvis and MacDuff, 1989). There is generally a decrease in root respiration, uptake of nutrients, and $\mathrm{N}$ fixation in legumes (Kang and Brink, 1995). The effect on the first two, respiration and nutrient uptake, may be dependent on plant age and resource availability (Sanderson et al., 1997).

Frequency and intensity of defoliation have different effects on root growth. Root growth has been shown to stop in several $\mathrm{C}_{3}$ forage grasses with removal of $50 \%$ or more of the shoots (Richards, 1993). A study by Kennedy and Russell, 1948, looked at the 
effects of various frequencies of defoliation of a Kentucky bluegrass and white clover pasture on root biomass at different depths. Generally, the greater the frequency of defoliation, the lower the quantity of roots and rhizomes in the top three inches of soil. There was no significant difference found in root mass between 1, 4 and 8-week defoliation intervals. However, when the defoliation frequency was reduced to every 12 weeks, root production and biomass significantly increased in the top three inches.

Nitrogen fixation may be severely reduced or stopped when legumes are defoliated. In white clover, 50\% defoliation has been shown to reduce the $\mathrm{N}$ fixation rate by $60-70 \%$ (Ryle et al., 1986). However, compared with many forage grasses, white clover root growth is not as affected by defoliation. Evans (1976) found that while $45 \%$ of perennial ryegrass roots died, only $5 \%$ of the white clover roots died with recurrent defoliation to a height of $2.5 \mathrm{~cm}$. However, Whitehead (1982), found that with continuous and severe defoliation of white clover during flowering, plant root mass was drastically reduced, but replacement of roots that senesce due to removal of aboveground herbage, is usually rapid.

\section{Effects of nitrogen on root growth}

Nitrogen is important to plant roots because it can be used for producing and altering root biomass (Vogt et al., 1993). Nitrogen usually encourages the production of roots used for absorption (Kolesnikov, 1971). Roots normally abound in areas of higher $\mathrm{N}$ concentration. The form of $\mathrm{N}$ taken up by a plant may determine the growth pattern and lifespan of fine roots (Vogt et al., 1993). Application of $\mathrm{N}$ in the form of ammonium resulted in smaller root biomass and less turnover of roots compared to $\mathrm{N}$ in the form of 
nitrate, the latter form of $\mathrm{N}$ supported more root biomass and more rapid root turnover (Smucker, 1984; Aber et al., 1985).

Nitrogen fertilizer may be used mainly for aboveground herbage production. This idea is supported by a study done by Holt and Fisher (1960), using Coastal Bermudagrass. Coastal Bermudagrass was treated with annual $\mathrm{N}$ applications ranging from 0 to 1,600 pounds per acre. Total plant mass for those plants subjected to the highest $\mathrm{N}$ rate was significantly higher than plants subjected to the lowest $\mathrm{N}$ rates. When plants were fertilized at the highest $\mathrm{N}$ rate, roots accounted for only $26 \%$ of the plant mass, and the root to shoot ratio was 1:2.78. For plants that received no N, roots contributed $76 \%$ of the dry weight, and the root to shoot ratio was $1: 0.32$. The highest $\mathrm{N}$ rate did not retard root growth, but it increased root growth and development only slightly.

\section{Root distribution and water uptake}

In the root zone, water content generally varies with time and space. The shallow layers in a soil profile usually are depleted of water first. Subsequent water uptake comes from increasing depths in the soil profile. The "relative distribution of roots" in a soil profile, with respect to depth, soil water retention, and water transmitting soil properties, determines the pattern of water uptake by a plant (Gardner, 1964). Overall, the distribution of a plant's roots is thought to be much more important than the number.

Gist and Smith, in 1948, studied root development of five forage grasses in West Virginia. The experiment involved existing stands of Kentucky bluegrass, orchardgrass (Dactylis glomerata L.), bromegrass (Bromus inermis Leyss.), timothy (Phleum pratense L.), and deer's tongue (Panicum clandestinum L.). Core samples, $7.6 \mathrm{~cm}$ in diameter, 
were taken from each stand and analyzed for the dry weight of roots at various depths (up to $46 \mathrm{~cm}$ ). In the top $7.6 \mathrm{~cm}$, Kentucky bluegrass had significantly more root development than did bromegrass or timothy. The high root density of Kentucky bluegrass in the top three inches of soil resulted in the buildup of a significantly higher percentage of soil OM over the course of 3 years. However, $7.6 \mathrm{~cm}$, Kentucky bluegrass root biomass declined more rapidly than did the other grasses. The authors felt that because Kentucky bluegrass has a shallower root system it may be more prone to dry matter yield reductions during dry periods.

\section{Acquisition and uptake of nutrients by roots}

The acquisition of nutrients by plant roots entails several processes, including obtaining the nutrients and influencing nutrient dynamics in the rhizosphere for plant root uptake (Hinsinger, 1998). The rhizosphere is "the volume of soil influenced by root activity" (Darrah, 1993). The extent of the rhizosphere and nutrient dynamics generally varies greatly for a given nutrient and plant species. Some plant species may develop more root hairs than others (Drew and Nye, 1969) and/or develop a symbiotic mycorrhizal relationship (Bolan, 1991). Differences in soil physical properties, such as particle size, soil structure, and water content can influence the transfer of ions to the rhizosphere, as well as ion concentration gradients in the soil (Nye, 1986). Plant roots may alter soil properties. For example, roots may reduce soil porosity by radial growth (Dexter, 1987; Bruand et al., 1996), or may reduce the rhizosphere water content by uptake (Hamza and Aylmore, 1992).

Roots can induce changes in ion concentration and $\mathrm{pH}$ in the rhizosphere. An important role of roots is water and nutrient uptake resulting in the accumulation or 
depletion of ions in the rhizosphere soil solution, true for essential, nonessential, and toxic elements. Ion concentration change is dependent on the supply of an ion as well as the plant's requirement for it (Hinsinger, 1998). Soil $\mathrm{pH}$ may also be affected by nutrient uptake. Generally, when nutrients are taken up by roots an imbalance of anions and cations occurs in the cells of the root. The root compensates for this charge imbalance by releasing protons when excess cations are taken up, and by releasing $\mathrm{OH}^{-}$or $\mathrm{HCO}_{3}{ }^{-}$when excess anions are taken up. The first situation results in rhizosphere acidification, the latter in its alkalinization (Haynes, 1990).

Nitrogen is an essential plant nutrient. It is also considered to be important in a plant's overall cation-anion balance, because it can be taken up as a cation, ammonium $\left(\mathrm{NH}_{4}{ }^{+}\right)$, an anion, nitrate $\left(\mathrm{NO}_{3}^{-}\right)$, or as a molecule, $\mathrm{N}$ gas $\left(\mathrm{N}_{2}\right)(\mathrm{Nye}, 1981)$. Several studies suggest that plants given ammonium acidify their rhizosphere. However, when given nitrate they alkalanize their rhizosphere (Riley and Barber, 1971; Weinberger and Yee, 1984; Gahoonia et al., 1992). Legumes, which use symbiotic $\mathrm{N}_{2}$ fixation, have been shown to compensate for excess cation uptake by acidifying their rhizosphere (Jarvis and Robson, 1983).

\section{Root competition}

Because plants in pasture systems are generally in crowded conditions, competition, not only between shoots but also between roots, can have a significant impact on root and shoot growth, and water and nutrient uptake. Competition between roots, in some instances, can affect plant growth more than shoot competition. Root density and distribution in the soil are the main factors determining below ground competition. Generally, root biomass decreases as soil depth increases (Nie et al., 1997), 
but plants with greater root densities usually have a competitive advantage. Root competition may also be influenced by root hair development and characteristics, mycorrhizal associations, physiological characteristics, and/or the plant's ability to alter patterns of root growth (Caldwell, 1987). The root system of white clover does not compete as effectively as the root systems of other legumes and grasses. Root competition between white clover and other plants can be more important than shoot competition (Wilkinson and Gross, 1964).

In 1963, Donald conducted a study to examine the root competition ability between perennial ryegrass and Phalaris tuberosa. The two species were grown together, each having the same available soil volume. Perennial ryegrass was shown to be superior, in terms of root competition, to Phalaris. When the root systems of the two species were intermingled, Phalaris showed a greater decrease in dry matter production. However, when the shoot systems of the two species were intermingled dry matter production did not decrease as much.

\section{Nitrogen and Pasture Production}

In the northeastern United States, pasture production is often seriously restricted by a lack of available nitrogen (Robinson and Sprague, 1946). Nitrogen deficiency may reduce photosynthesis, plant growth, cell size, leaf elongation, and protein content. Under N-limiting conditions, tall fescue (Festuca arundinacea Schreber) was shown to have only $70 \%$ of maximum canopy gross photosynthesis (Gastal and Belanger, 1993) and increased partitioning of carbon within the plant (Belanger et al., 1992). Reduced CP concentration is the major effect of $\mathrm{N}$ stress on pasture quality (Sanderson et al. 1997). In 
response to an $\mathrm{N}$ deficiency, a plant may remobilize $\mathrm{N}$ from other organs. In perennial grasses, this reduced supply of $\mathrm{N}$ may result in more fine roots at microsites with high $\mathrm{N}$, as well as increased root hair density and length (Boot and Mensink, 1990; Crick and Grime, 1987).

Because grasses are unable to fix $\mathrm{N}$, it is often recommended meadows and pastures be fertilized. Addition of $\mathrm{N}$ generally increases herbage accumulation by increasing the rate of leaf area development and light interception (Gastal and Belanger, 1993). Nitrogen fertilization may also increase forage nutritive value. The incorporation of legumes, such as white clover, into pastures, is an economical method for supplying N. Fertilization of pasture using inorganic $\mathrm{N}$ is another method commonly employed to increase grassland production.

\section{Legumes as a source of nitrogen for pastures}

Atmospheric $\mathrm{N}$ may be fixed between legumes and rhizobia and transferred to neighboring non-leguminous species. Legumes contribute $\mathrm{N}$ below ground by the decay of nodules, legume root exudation and/or a mycorrhizal fungal link between legume and grass roots (Laidlaw et al., 1996). The annual amount of $\mathrm{N}$ fixed by white clover, varying according to clover yields and mineral $\mathrm{N}$ availability, may range from 66 to 100 $\mathrm{kg} \mathrm{N} \mathrm{ha}^{-1} \mathrm{yr}^{-1}$ in Nova Scotia, Canada, and 45 to $390 \mathrm{~kg} \mathrm{~N} \mathrm{ha}^{-1} \mathrm{yr}^{-1}$ in New Zealand (Caradus, 1990). Environmental factors, such as high soil nitrate levels, low soil pH, clover defoliation, high temperatures, moisture stress, low light intensity, and pests, may reduce white clover root nodulation. Also, white clover populations in pastures often fluctuate with consequent fluctuations in the $\mathrm{N}$ contribution from the legumes. 
Dubach and Russelle (1994) cite several studies showing that only a small amount of $\mathrm{N}$ is released by excretion from roots and nodules, compared to the amount of $\mathrm{N}$ fixed from the atmosphere. Therefore, it is thought that the release of $\mathrm{N}$ from dead roots and nodules in grass/legume mixtures is generally the main source of transferable $\mathrm{N}$ (Dubach and Russelle, 1994; Laidlaw et al. 1996).

A study by Dubach and Russelle in 1994, involving established alfalfa (Medicago sativa L.) and birdsfoot trefoil (Lotus corniculatus L.), attempted to quantify the origin and amount of $\mathrm{N}$ in nodules and fine roots. Alfalfa shoots were harvested during weeks 8 and 12 after being transplanted to a growth chamber; the shoots of birdsfoot trefoil were harvested during week 10 after being transplanted to a growth chamber. The authors found that legume root $\mathrm{N}$ concentration was higher in fine roots that were produced during the first 2 weeks of regrowth after harvesting, compared to fine roots produced just prior to harvest. However, the $\mathrm{C} / \mathrm{N}$ ratios were lower. Also, root $\mathrm{N}$ content did not change over time. Dead nodules of alfalfa and birdsfoot trefoil contained about one-third of the $\mathrm{N}$ content of living nodules. The authors attributed this to the $\mathrm{N}$ being remobilized to living nodules. Total $\mathrm{N}$ potentially available for transfer upon root senescence ranged from 3.4 to $15.6 \mathrm{~kg} \mathrm{ha}^{-1} \mathrm{~m}^{-1} \mathrm{yr}^{-1}$ for alfalfa and 1.1 to $3.5 \mathrm{~kg} \mathrm{ha}^{-1} \mathrm{~m}^{-1} \mathrm{yr}^{-1}$ for birdsfoot trefoil, depending on depth. The total $\mathrm{N}$ potentially available for transfer upon nodule death was 0.2 to 1.8 and 0.2 to $6.6 \mathrm{~kg} \mathrm{ha}^{-1} \mathrm{yr}^{-1}$, depending on depth, for alfalfa and birdsfoot trefoil, respectively. The authors felt that these results support the idea that $\mathrm{N}$ released from decaying roots and nodules, although not the primary source of $\mathrm{N}$ is a major source of $\mathrm{N}$ for companion plants (Dubach and Russelle, 1994). 
Laidlaw et al. examined the rate of $\mathrm{N}$ turnover from white clover roots relative to grass roots due to decomposition in 1996. A three-year-old perennial ryegrass and white clover mixed sward, continuously grazed by steers, was studied over two, 2-week periods. Subplots were treated with $\mathrm{N}^{15}$, harvested, and $7.5 \mathrm{~cm}$ diameter by $10 \mathrm{~cm}$ deep root cores were extracted. Turnover was estimated as the difference between the net accumulation rate of $\mathrm{N}$ and the mean assimilation rate into roots for the two periods. The authors found that $\mathrm{N}$ turnover and assimilation in grass roots was slower and much lower than in clover roots and stolons. They estimated the loss of $\mathrm{N}$ from perennial ryegrass roots to be $0.7 \mathrm{mg} \mathrm{N} \mathrm{m}^{-2} \mathrm{~d}^{-1}$ and $8.0 \mathrm{mg} \mathrm{N} \mathrm{m}^{-2} \mathrm{~d}^{-1}$ for white clover. Since $\mathrm{N}$ loss estimates were made in the autumn, when it is common for root and stolon biomass to decline, the authors felt that the $\mathrm{N}$ turnover rate for clover would be higher for the entire grazing season. The grass root fraction, however, may have been overestimated. This is because grass roots were not the only roots included in the sample. Any roots that were not white clover roots, such as weed roots, were included with the grass root fraction.

\section{Addition of nitrogen fertilizer to pastures}

Nitrogen fertilizers are commonly added to pastures to increase herbage accumulation and forage nutritive value. Optimum rates of $\mathrm{N}$ vary for several reasons, including forage species, soil moisture, climate, cost of the fertilizer, and economic benefit. Numerous experiments have shown the benefits of adding $\mathrm{N}$ fertilizer to pastures, and have examined appropriate rate and timing of applications.

Robinson and Sprague (1946) studied the effects of $\mathrm{N}$ fertilizer applications and cutting frequency Kentucky bluegrass and white clover pasture. Nitrogen was applied at $40 \mathrm{lb} \mathrm{ac}^{-1}$ in early spring and after each harvest except the last fall harvest. Because 
cutting frequencies varied, the total amount of $\mathrm{N}$ applied in a year was greater at higher cutting frequencies. Plots treated with $\mathrm{N}$ had higher dry matter yields than plots to which no $\mathrm{N}$ was applied. A similar study conducted by Swift et al. (1948) in Pennsylvania found that the lowest content of Kentucky bluegrass, in a Kentucky bluegrass/white clover pasture, was on a plot that received no fertilizer. It was found that as fertilizer applications increased, so did the Kentucky bluegrass dry matter yield. However, the yield of white clover decreased.

Raese and Decker (1966) conducted an experiment to examine how yield and stand persistence is affected by $\mathrm{N}$ fertilization. Orchardgrass, bromegrass, and reed canarygrass (Phalaris arundinacea L.) were seeded, fertilized with 25 or $75 \mathrm{lb} \mathrm{N} \mathrm{ac}^{-1}$, and harvested at either pre-joint, early head, early bloom, or late bloom growth stages. Each stage, except pre-joint, was cut to 1.5 or 3.5 inches. Dry matter production was determined, and stands were rated from 1 to 10 according to percent groundcover, where 10 was equal to $100 \%$ groundcover. It was found that yield increased significantly with increasing $\mathrm{N}$ applications. However, the higher levels of $\mathrm{N}$ significantly reduced the stands of orchardgrass and bromegrass, whereas reed canarygrass stands responded favorably to the high $\mathrm{N}$ level.

High $\mathrm{NO}_{3}{ }^{-}$content in forage is a potential drawback of $\mathrm{N}$ fertilizer application. Excess $\mathrm{N}$ can accumulate as $\mathrm{NO}_{3}{ }^{-}$when the rate of nitrate uptake exceeds the rate of protein synthesis. Slower plant growth, photosynthesis, and absorption of phosphate may result in nitrate accumulation. This accumulation may affect animal health and forage protein quality and degradability of the protein by a ruminant. Nitrate poisoning in 
animals may cause rapid breathing, bluing of mucous membranes, and death due to asphyxiation (Sanderson et al., 1997).

\section{Effect of nitrogen fertilizer on legume populations}

Another potential drawback of adding $\mathrm{N}$ fertilizer to a mixed sward is reduced legume population. Birdsfoot trefoil and white clover, in mixed swards, have been shown to decrease when 200 to $400 \mathrm{lb} \mathrm{N} \mathrm{ac}^{-1}$ is added, compared to stands with no $\mathrm{N}$ added (Wolf and Smith, 1964). However, several factors, such as grazing frequency and height, and soil moisture, may also affect legume persistence. In a study by Robinson and Sprague (1946), white clover populations, $\mathrm{N}$ fertilization, defoliation, and soil moisture were examined. They found that, generally, with high $\mathrm{N}$ fertilization, clover populations decreased significantly. During the second year of the experiment, white clover ranged from 33 to $57 \%$ in the swards when no $\mathrm{N}$ was applied; with the high $\mathrm{N}$ application clover ranged from 1 to $60 \%$. Clover populations were less affected by high $\mathrm{N}$ applications when soil moisture was adequate and when the swards were under severe clipping management. The high $\mathrm{N}$ and irrigated treatment that was cut to 0.5 to 1.0 in when the sward reached 3 to 5 in resulted in the highest clover population $(60 \%)$.

\section{Legumes versus nitrogen fertilizer for pastures}

It is generally accepted that the addition of legumes to a pure grass stand increases dry matter yield and results in more even seasonal forage distribution (Jones, 1967). Legumes usually have higher protein percentages than do grasses. Also, grasses have increased protein content when grown in association with legumes (Churchill, 1947). This higher forage quality has been found to consistently increase output per animal (Blaser et al., 1956; Heinemann and VanKeuren, 1958; Jordon and Wedin, 1961). 
Although dry matter production was the same, stands consisting of 30 to $45 \%$ legumes were found to significantly increase milk production acre ${ }^{-1}$ compared to stands of pure grass (Austenson et al., 1959). Similarly, a study conducted by Williams (1967) showed that the number of calves per cow and the weaning weights of the calves were greater for cows grazing grass-legume mixed pastures than for those cows grazing pastures fertilized with $\mathrm{N}$.

However, it has also been shown that higher dry matter yields are produced by $\mathrm{N}$ fertilization of pastures. Clark et al. (1966) conducted a three-year experiment to compare $\mathrm{N}$ fertilized grasses and grass-legume mixtures. The treatments were compared based on forage dry matter production, pasture carrying capacity, and milk production. The four treatments were: orchardgrass-white clover mixed sward and orchardgrass with 100,200 , and $300 \mathrm{lb} \mathrm{N} \mathrm{ac}^{-1}$ applied in four split applications annually. Two lactating cows were assigned to each replication of each treatment. Nitrogen applications significantly increased the dry matter production of the orchardgrass as compared to the orchardgrass-white clover mixture. These higher dry matter yields dictated the carrying capacity. As $\mathrm{N}$ rate increased, so did the $\mathrm{CP}$ content of the forage. Because the clover population went from $46 \%$ in year one to $3 \%$ in year three the $\mathrm{CP}$ and the dry matter yield of the mixed sward steadily decreased. Generally, milk production $\operatorname{cow}^{-1}$ was higher for the grass-clover pasture; nevertheless, as the clover population decreased, milk production $\operatorname{cow}^{-1}$ of the orchardgrass plus $\mathrm{N}$ and the mixed pasture treatments became similar. The authors concluded that white clover could be efficiently grown in association with orchardgrass for 2 to 3 years. However, they felt that, when the clover 
population begins to decline, applications of up to $200 \mathrm{lb} \mathrm{N} \mathrm{ac}{ }^{-1}$ could significantly increase orchardgrass dry matter yield.

\section{Timing of nitrogen applications}

Timing of $\mathrm{N}$ fertilizer applications plays an important role in herbage accumulation and quality of forages. Dawson and Ryden (1985) found that when $130 \mathrm{~kg}$ $\mathrm{N} \mathrm{ha}^{-1}$ was applied to ryegrass swards in spring, the uptake of $\mathrm{N}$ in mid-season was lower than swards fertilized at a rate of $40 \mathrm{~kg} \mathrm{~N} \mathrm{ha}^{-1}$. Also, at the $130 \mathrm{~kg} \mathrm{~N}^{-1}$ rate, the ryegrass appeared to suffer greater from water stress.

Centipedegrass (Eremochloa ophiuroides Hack.), if subject to high levels of $\mathrm{N}$ at inappropriate times, may experience a decline of growth that includes slow spring greening, becoming chlorotic, and possibly death (Johnson and Carrow, 1988). Johnson et al. (1988) found that $\mathrm{N}$ applied at a rate of $100 \mathrm{~kg} \mathrm{ha}^{-1}$ in April and $100 \mathrm{~kg} \mathrm{~N} \mathrm{ha}^{-1}$ in September improved the quality of the centipedegrass. It also reduced the decline of the grass significantly, compared to a single application of $100 \mathrm{~kg} \mathrm{~N} \mathrm{ha}^{-1}$ in April. However, during the fourth and fifth years of the experiment, the split application of $\mathrm{N}$ in April and September resulted in grass of lower quality than the single application of $\mathrm{N}$ in April. A similar study of centipedegrass revealed that a $100 \mathrm{~kg} \mathrm{~N} \mathrm{ha}^{-1}$ split application applied in April and July resulted in higher quality grass compared to 3 to 4 split applications of $\mathrm{N}$ equaling $100 \mathrm{~kg} \mathrm{ha}^{-1}$ (Johnson and Carrow, 1988).

Timing may also affect pest resistance and over-wintering capability of a grass. Applying $\mathrm{N}$ in late autumn or close to winter may increase grass growth. This rapid growth can prevent plants from becoming winter-hardy, because plants cannot be frost hardened during rapid growth (Dexter, 1956). High $\mathrm{N}$ applications may affect winter 
survival of grasses (Carroll and Welton, 1939). Orchardgrass fertilized with 364 to 532 $\mathrm{kg} \mathrm{N} \mathrm{ha}^{-1}$ had a lower winter survival rate than stands of orchardgrass fertilized with 140 to $196 \mathrm{~kg} \mathrm{~N} \mathrm{ha}^{-1}$ (Howell and Jung, 1965). Sheard (1970) found that an application of 56 $\mathrm{kg} \mathrm{N} \mathrm{ha}^{-1}$ applied to timothy in early September resulted in the greatest increase in shoot and root growth of the grass. Nitrogen applications exceeding $168 \mathrm{~kg} \mathrm{~N} \mathrm{ha}^{-1}$ generally resulted in lower herbage accumulations and growth rates. 


\section{MATERIALS AND METHODS}

The experiment was carried out over a period of two years (1999 and 2000) on the West Virginia University Livestock farm near Morgantown, WV (39 $39^{\circ}$ N latitude and $79^{\circ} 55^{\prime} \mathrm{W}$ longitude). The area used for the experiment is a moderately sloped native pasture and has been traditionally used for the grazing of cattle. The pasture consisted mainly of Kentucky bluegrass and white clover. The plots were located on the Dormont soil series, which is a deep, moderately well drained, fine-loamy Ultic Hapludalf. The slope of the plots was 10 to $17 \%$.

\section{Experimental Treatments and Design}

The effects of two factors were examined in the experiment (Table 1). The first factor was $\mathrm{N}$ fertilization. Nitrogen was applied in the form of ammonium nitrate $\left(\mathrm{NH}_{4} \mathrm{NO}_{3}\right)$ at three rates: $0 \mathrm{~kg} \mathrm{~N} \mathrm{ha}^{-1}\left(0 \mathrm{lb} \mathrm{N} \mathrm{ac}^{-1}\right), 80 \mathrm{~kg} \mathrm{~N}^{-1}\left(71 \mathrm{lb} \mathrm{N} \mathrm{ac}^{-1}\right)$, and $160 \mathrm{~kg}$ $\mathrm{N} \mathrm{ha}^{-1}$ (143 $\mathrm{lb} \mathrm{N} \mathrm{ac}^{-1}$ ) each year, split in two equal applications. These $\mathrm{N}$ application times were chosen to come immediately after the peak of Kentucky bluegrass spring growth and at the beginning of its regrowth after summer. The second factor was the cutting regimen. Plots were allowed to grow to12.7 $\mathrm{cm}$ (5.0 in). When they reached 12.7 $\mathrm{cm}$, they were then cut to one of three heights: $2.5 \mathrm{~cm}(1.0 \mathrm{in}), 5.1 \mathrm{~cm}(2.0$ in) or $7.6 \mathrm{~cm}$ (3.0 in). The cutting heights represented grazing intensity. The experimental design was a randomized complete block with a 3 (nitrogen) x 3 (clipping height) factorial arrangement of treatments. Four blocks, each with 9 plots, a total of 36 plots, made up the experimental area. Each of the plots had an area of $2 \times 4 \mathrm{~m}$ (Fig. 1). A section of 
Table 1: Experimental treatments and treatment abbreviations.

\begin{tabular}{cc}
\hline Treatment & Treatment Abbreviation \\
\hline $\mathbf{N}$ & none \\
$0 \mathrm{~kg} \mathrm{~N} \mathrm{ha}^{-1}$ & medium \\
$80 \mathrm{~kg} \mathrm{~N} \mathrm{ha}^{-1}$ & high \\
$160 \mathrm{~kg} \mathrm{~N} \mathrm{ha}^{-1}$ & \\
& \\
Cutting & $2.5 \mathrm{~cm}$ \\
$2.5 \mathrm{~cm}(1 \mathrm{in})$ & $5.1 \mathrm{~cm}$ \\
$5.1 \mathrm{~cm}(2 \mathrm{in})$ & $7.6 \mathrm{~cm}$ \\
$7.6 \mathrm{~cm}(3 \mathrm{in})$ &
\end{tabular}

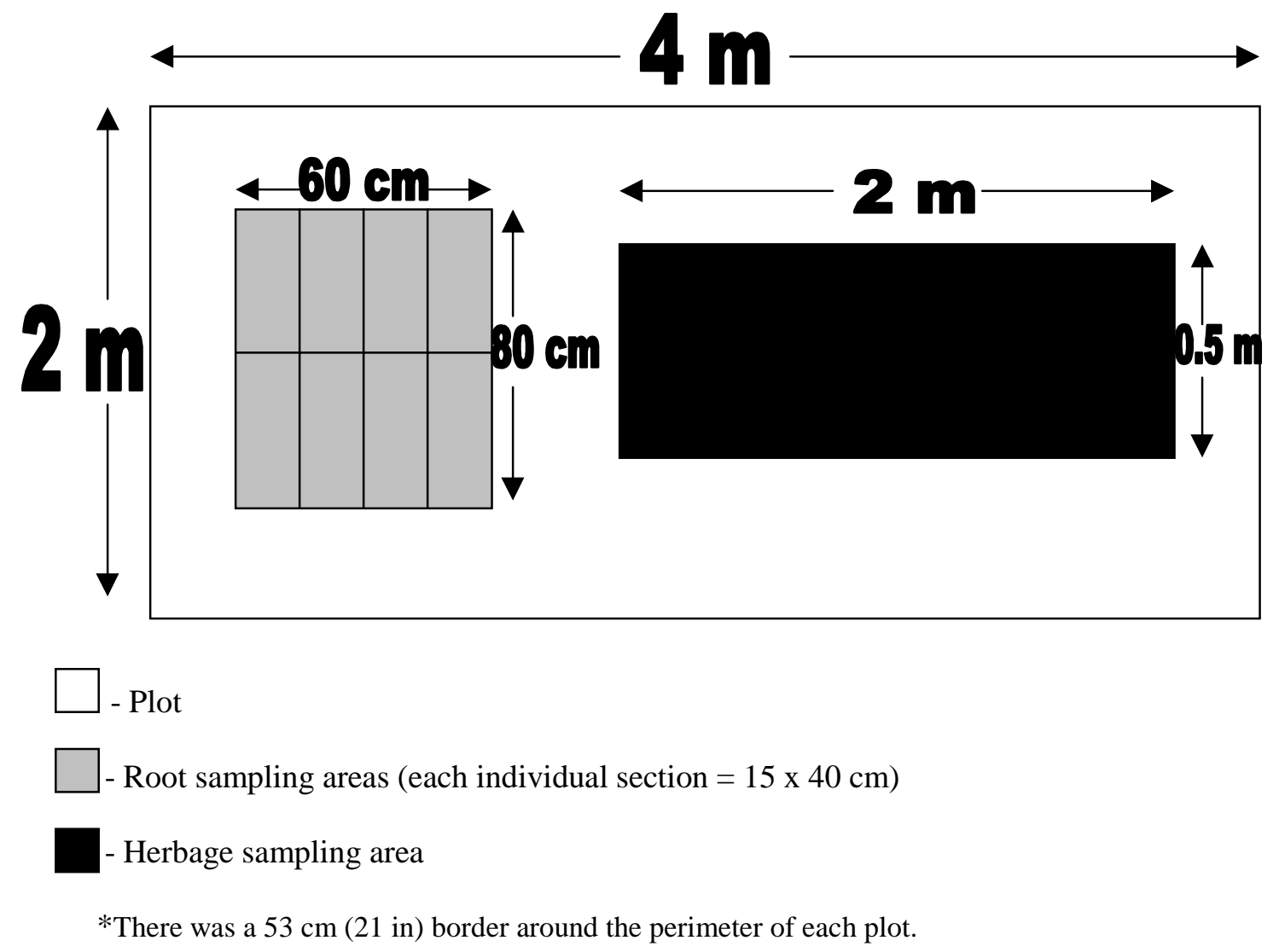

Figure 1: Experimental plot layout indicating the designated sampling areas 
$60 \times 80 \mathrm{~cm}$ within each plot and was divided into eight $15 \times 40 \mathrm{~cm}$ sampling areas, designated for destructive sampling of roots and insertion of anion transfer membranes. Each destructive sampling area was randomly assigned to a root sampling time, one through eight. A different area was used at each sampling time. Anion transfer membranes were placed in areas assigned to the next scheduled root core sample. Herbage accumulation was measured using a plate meter (Bryan et al., 1989; Rayburn and Rayburn, 1998). Herbage accumulation was estimated by harvesting the $0.5 \times 2.0 \mathrm{~m}$ area in each plot. The herbage and root sampling sections were randomly assigned to the top or bottom of each plot. Successive harvests were made from the same area.

\section{The 1999 season}

The area for the experiment was cut to $1.27 \mathrm{~cm}(0.5 \mathrm{in})$ using a rotary lawn mower with a bag attachment in March 1999, and the cut material was removed. Soil samples, at $0.0-5.1 \mathrm{~cm}(0-2 \mathrm{in})$ and $0.0-7.6 \mathrm{~cm}(0-3 \mathrm{in})$ depths were taken in each plot. No soil amendments were added. Plots cut to $7.6 \mathrm{~cm}$ were harvested three times. The $5.1 \mathrm{~cm}$ treatment plots were harvested twice. All of the $2.5 \mathrm{~cm}$ treatment plots were harvested once, and the $2.5 \mathrm{~cm}$ cutting treatments with medium and high nitrogen applications were cut an additional time (Table 2). The cutting dates were divided into 3 harvest periods (Table 3). Nitrogen was applied according to treatment on June 3, 1999 and September 10, 1999. Prior to both of these applications anion transfer membranes were placed in each plot to measure $\mathrm{NO}_{3}{ }^{-}$concentrations in the soil. A root core sample from each plot was taken in April, May, September and October (Table 4). 


\section{The 2000 season}

In 2000 , all $7.6 \mathrm{~cm}$ treatment plots were harvested seven times, all $5.1 \mathrm{~cm}$ treatment plots were harvested six times, and all $2.5 \mathrm{~cm}$ treatment plots were harvested four times (Table 2). The cutting dates were again divided into 3 harvest periods (Table 3). On June 2, 2000 and August 30, $2000 \mathrm{~N}$ was applied and anion transfer membranes were placed in each plot. Root samples were taken three times from each plot: May, August, and October (Table 4). Soil samples, at $5.1 \mathrm{~cm}(2 \mathrm{in})$ and $7.6 \mathrm{~cm}$ (3 in) depths were taken from each plot in October.

Table 2: Treatment harvest frequencies for 1999 and 2000.

\begin{tabular}{cccc}
\hline \multicolumn{2}{c}{ Treatment } & \multicolumn{2}{c}{ Harvest Frequency } \\
\hline Cut & $\mathrm{N}$ & 1999 & 2000 \\
\hline $\mathrm{cm}$ & $\mathrm{kg} \mathrm{N} \mathrm{ha}^{-1}$ & ------ & $\#$ \\
2.5 & 0 & 1 & 4 \\
& 80 & 2 & 4 \\
& 160 & 2 & 4 \\
& & & \\
5.1 & 0 & 2 & 5 \\
& 80 & 2 & 5 \\
& 160 & 2 & 5 \\
7.6 & 0 & 3 & 7 \\
& 80 & 3 & 7 \\
& 160 & 3 & 7 \\
\hline
\end{tabular}


Table 3: Harvest period designations for harvest cutting dates in 1999 and 2000.

\begin{tabular}{ccc}
\hline & \multicolumn{2}{c}{ Year } \\
\cline { 2 - 3 } Havrest period & $\mathbf{1 9 9 9}$ & $\mathbf{2 0 0 0}$ \\
\hline 1 & Beginning of Season to May 31 & Beginning of Season to May 31 \\
2 & June 1 to August 31 & June 1 to July 31 \\
3 & September 1 to end of season & August 1 to end of season \\
\hline
\end{tabular}

Table 4: Root sampling dates for 1999 and 2000.

\begin{tabular}{|c|c|c|c|}
\hline \multicolumn{4}{|c|}{ Year } \\
\hline \multicolumn{2}{|c|}{1999} & \multicolumn{2}{|c|}{2000} \\
\hline Month/day & Julian date & Month/day & Julian date \\
\hline Apr 15 & 105 & & \\
\hline May 27 & 147 & May 30 & 151 \\
\hline Sept 22 & 265 & Aug 28 & 241 \\
\hline Oct 25 & 298 & Oct 13 & 287 \\
\hline
\end{tabular}

\section{Pasture Production and Quality}

Using a garden drop fertilizer spreader, $\mathrm{NH}_{4} \mathrm{NO}_{3}$ fertilizer was applied to each plot. Fertilizer was applied first to the center of the plot. This ensured proper coverage of the harvest and destructive sampling areas. The sides and ends were then fertilized.

Herbage in the $0.5 \times 2 \mathrm{~m}(1.75 \times 6.5 \mathrm{ft})$ herbage sampling area was cut and collected. A rotary lawn mower with a bag attachment was used to harvest herbage. Mower height was adjusted according to cutting height treatment. The rest of the plot was then cut and herbage removed and collected. 


\section{Herbage accumulation}

Herbage from the sampling area was collected and weighed on a scale in the field. Sub-samples were taken, weighed and dried for $48 \mathrm{~h}$ at $65 \mathrm{C}$. Herbage accumulation was as the herbage weight multiplied by the dry matter percentage of the sub-sample. These dried sub-samples were ground through a $1 \mathrm{~mm}$ mesh screen in a Wiley Mill and placed in plastic bags for fiber and $\mathrm{N}$ analysis. For successive harvests, herbage on each plot was allowed to grow to $12.7 \mathrm{~cm}$ and then was cut according to its designated treatment. Harvesting and sampling methods were repeated.

\section{Total Kjeldahl nitrogen}

Using the macro-Kjeldahl method, the dried and ground samples were analyzed for N content (Horneck and Miller, 1998; Jones, 1991). Duplicates of each sample were placed in a Tecator digestion system 1015 digester. They were then analyzed on a Tecator Kjeltec Auto 1030 Analyzer. Crude protein was calculated on a dry weight basis as the total Kjeldahl $\mathrm{N}$ multiplied by 6.25 . Crude protein yield was calculated by:

$$
\mathrm{CP} \text { yield }=(\text { Herbage accumulation } \mathrm{x} \mathrm{CP} \text { concentrations }) / 100
$$

\section{Neutral detergent fiber and acid detergent fiber}

Neutral detergent fiber and ADF content were determined using the Ankom procedure (Ankom Technology, 1997a and b). Approximately $0.50 \mathrm{~g}$ of dried subsample were placed in Ankom Technology F57 filter bags and sealed (Ankom Technology, 1997a). Samples were digested in the sealed filter bags in an Ankom 200 Fiber Analyzer. They were then dried for $48 \mathrm{~h}$ at $65 \mathrm{C}$ and reweighed. Percent NDF on a dry matter basis was determined using the following equation:

$$
\% \mathrm{NDF}=\left[100\left(\mathrm{~W}_{3}-\left(\mathrm{W}_{1} \times \mathrm{C}\right)\right] / \mathrm{W}_{2}\right.
$$


where $\mathrm{W}_{1}=$ bag tare weight, $\mathrm{W}_{2}=$ sample weight, expressed on a dry matter basis, $\mathrm{W}_{3}=$ final bag and NDF fiber weight, and C = blank bag correction (final oven-dried weight/original blank bag weight).

The Ankom procedure was used for determining percent ADF (Ankom Technology, 1997b). The material left from NDF digestion were again digested in an Ankom 200 Fiber Analyzer, dried for $48 \mathrm{~h}$ at $65 \mathrm{C}$ and reweighed. The following equation was used to determine percent $\mathrm{ADF}$ on a dry matter basis:

$$
\% \mathrm{ADF}=\left[100\left(\mathrm{~W}_{4}-\left(\mathrm{W}_{1} \times \mathrm{C}\right)\right] / \mathrm{W}_{2}\right.
$$

where $\mathrm{W}_{1}=$ bag tare weight, $\mathrm{W}_{2}=$ sample weight, expressed on a dry matter basis, $\mathrm{W}_{4}=$ final bag and ADF fiber weight, and C = blank bag correction (final oven-dried weight/original blank bag weight).

\section{Pasture Root Growth}

Using a golf hole cutter, one $10 \mathrm{~cm}$ (4.0 in) diameter, $20.3 \mathrm{~cm}$ ( 8 in) deep soil/root core was extracted from each plot in mid-April, late May, late September, and late October during 1999. In 2000, samples were removed from all plots three times: late May, late August, and mid-October (Table 4). The samples were taken from their assigned areas in the destructive portion of each plot (Fig. 1), placed in plastic bags and refrigerated. The root cores were divided into three sections according to the following depths: $0.0-5.1 \mathrm{~cm}(0.0-2.0 \mathrm{in}), 5.1-10.2 \mathrm{~cm}(2.0-4.0 \mathrm{in})$, and $10.2-20.3 \mathrm{~cm}(4.0-$ 8.0 in). Roots in each section were washed free of soil through a mesh screen, placed in plastic bags and frozen until they were analyzed. 


\section{Root volume}

The roots were thawed and placed on absorbent paper towels to remove excess water. The wet weight was taken, and the root volume was determined by water displacement.

\section{Root length}

Root length was measured on samples from plots in blocks 3 and 4 that received the following treatment combinations: $2.5 \mathrm{~cm}$ cut/no N, $2.5 \mathrm{~cm}$ cut/high N, $7.6 \mathrm{~cm} \mathrm{cut/no}$ $\mathrm{N}$ and $7.6 \mathrm{~cm}$ cut/high $\mathrm{N}$. Root length of each section was determined using

ROOTEDGE (Kaspar and Ewing, 1997). Roots were separated and placed on a HewlettPackard desktop scanner. Using a microcomputer, the roots were scanned and a black and a white computer TIFF image file for each sample was created. Two or three images per sample were made if the size prevented the entire sample from being placed on the scanner. Difficulties were encountered separating the fine grass roots. Although time and care were taken the samples did contain overlapping roots as well as several roots in a group. This was especially a problem for the $0.0-5.1 \mathrm{~cm}$ root sampling depth. The computer images were then analyzed using the DOS-based ROOTEDGE program to determine the overall length of the root sample. This program measures the length $(\mathrm{cm})$ of roots using the edge chord algorithm (Ewing and Kaspar, 1995). For samples requiring more than one TIFF image, lengths determined for each image of the sample were summed.

\section{Root dry weight}

After the root lengths of the samples were determined, samples were dried for approximately $48 \mathrm{~h}$ in a $65 \mathrm{C}$ oven, and weighed to determined dry root mass. 


\section{Soil Nitrate}

Prior to each $\mathrm{N}$ application, an anion transfer membrane strip was placed in each plot to determine soil nitrate levels $\left(\mathrm{NO}_{3}{ }^{-}\right)$. The membranes were prepared for placement into the soil. They were washed with deionized distilled water, agitated in $0.5 \mathrm{M} \mathrm{HCl}$, rewashed with deionized distilled water, saturated with $1 \mathrm{M} \mathrm{NaCl}$ for $2 \mathrm{~h}$ and rinsed three times with deionized distilled water (Ionics, 1990; Collins and Allinson, 1999). A string was attached to one end to ease removal from the soil. At an approximate depth of 15 $\mathrm{cm}$, one prepared membrane, $2.5 \times 6.25 \mathrm{~cm}$, was placed in each plot, in the $15 \times 40 \mathrm{~cm}$ area for the successive root core. Using a shovel with a flat blade, a wedge (approximately 1-in deep) was created and removed. A $15 \mathrm{~cm}$ deep slit was made with the shovel, any extraneous herbage was removed and an anion transfer membrane was placed in the slit. The soil wedge was replaced and tamped down to ensure adequate soilmembrane contact.

Due low rainfall the anion transfer membranes were allowed to remain in the soil for $20 \mathrm{~d}$ in June 1999, $17 \mathrm{~d}$ in September 1999 and $22 \mathrm{~d}$ in September 2000. The anion transfer membranes remained in the plots for $11 \mathrm{~d}$ in June 2000. The membranes were removed from the soil by dislodging the soil wedge and gently pulling on the string attached to the end of the anion transfer membrane. Once removed, the anion transfer membranes were rinsed with deionized distilled water to remove soil. In 1999, the membranes were combined by block and $\mathrm{N}$ treatment, and placed in $30 \mathrm{ml}$ of a $1 \mathrm{M} \mathrm{NaCl}$ solution. However, in 2000 anion transfer membranes from each plot were kept separate and analyzed individually. 
The $\mathrm{NO}_{3}{ }^{-}$was extracted from the anion transfer membranes by agitating the membranes in the $1 \mathrm{M} \mathrm{NaCl}$ solution for $2 \mathrm{~h}$ on a wrist action shaker. Anion transfer membranes were then removed from the solutions and discarded. Extract solutions were filtered through Whatman 42 filter paper. Nitrate concentration was determined colormetrically by low flow injection analysis on a Lachat QuikChem FIA+8000. Nitrate concentrations were reported as $\mathrm{mg} \mathrm{N}^{-1}$. Concentrations were converted to $\mu \mathrm{g} \mathrm{N} \mathrm{cm}^{-2}$ $\mathrm{d}^{-1}$.

\section{Climate Report}

Daily minimum and maximum temperatures and daily precipitation were obtained from the Morgantown Municipal airport for the period March to October of 1999 and 2000.

\section{Statistical Analysis}

Treatment effects on herbage accumulation, forage quality, CP yield, root growth parameters and soil $\mathrm{NO}_{3}{ }^{-}$were analyzed using the general linear model procedure (SAS, 1990). Differences between $\mathrm{N}$ and cutting treatments, harvest periods and harvest dates were compared using orthogonal contrasts. No $\mathrm{N}$ was compared with the medium and high $\mathrm{N}$, and medium $\mathrm{N}$ was compared to high $\mathrm{N}$. The $2.5 \mathrm{~cm}$ cutting management was compared with the 5.1 and $7.6 \mathrm{~cm}$ cutting managements, and the $5.1 \mathrm{~cm}$ cutting management was compared with the $7.6 \mathrm{~cm}$ cutting management. For herbage accumulation and quality, harvest period 1 was compared with harvest periods 2 and 3 , and harvest period 2 was compared with harvest period 3. There were six orthogonal 
comparions for root sampling dates. The pre-treatment root samples (April 15, 1999)

were compared with the post-treatment root samples (May 27, 1999 to October 13, 1999).

The 1999 season was compared with 2000. September 22, 1999 was compared with the May 27 and October 25, 1999, and May 27, 1999 was compared with October 25, 1999. August 28, 2000 was compared with May 30 and October 13, 2000, and May 30, 2000 was compared with October 13, 2000. 


\section{RESULTS}

\section{Pasture Production and Quality}

\section{Herbage accumulation}

Annual herbage accumulation was not affected by any of the $\mathrm{N}$ treatments (Table 5 and Appendix Table A). However, cutting management did affect the annual herbage accumulation $(\mathrm{P}<0.0001)$. Pasture cut to $2.5 \mathrm{~cm}$ cut produced much more herbage than pasture cut to 5.1 or $7.6 \mathrm{~cm}$. The significant interaction $(\mathrm{P}<0.05)$ found between cutting management and year did not change the main effect results (Fig. 2).

Herbage accumulation in 2000 was much greater than in $1999(\mathrm{P}<0.0001)$. In 2000, $4009 \mathrm{~kg} \mathrm{ha}^{-1}$ was harvest compared to $1962 \mathrm{~kg} \mathrm{ha}^{-1}$ harvested in 1999. An interaction $(\mathrm{P}<0.01)$ between $\mathrm{N}$ level, cutting management and year was also found.

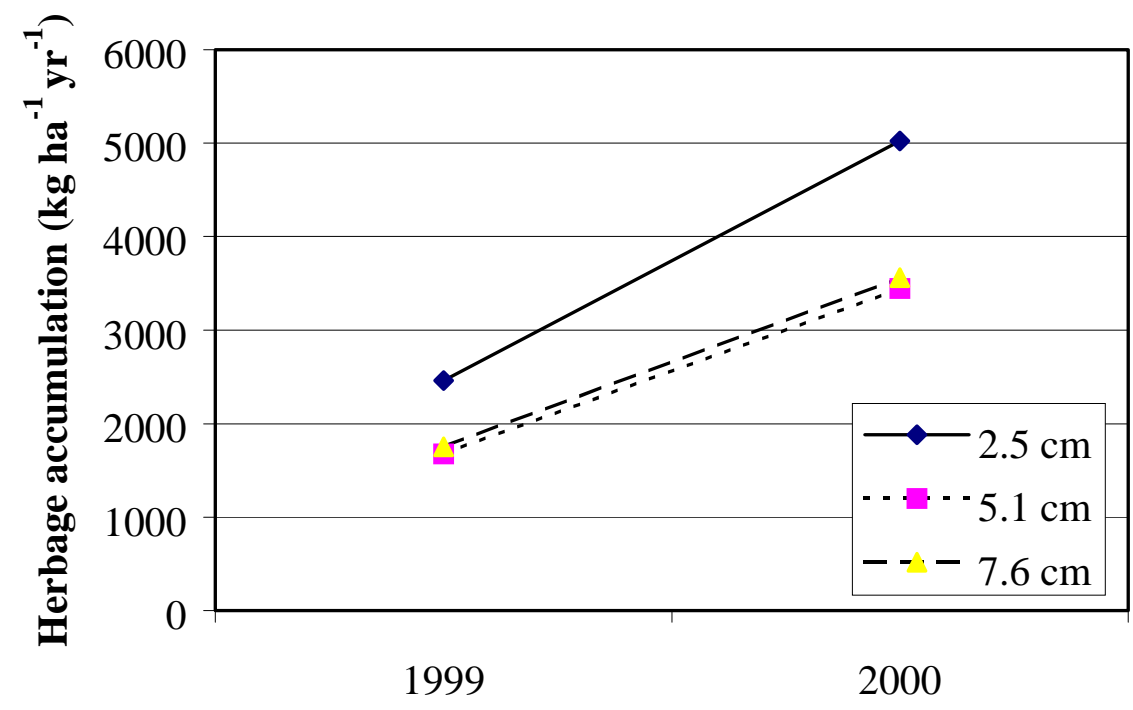

Year

Figure 2: Effect of year and cutting management on annual herbage accumulation. The interaction between year and cutting management was significant at $P$ $<0.05$. Year was significant at $\mathrm{P}<0.0001$, and cutting management was significant at $\mathrm{P}$ $<0.0001$. 
Table 5: Effect of $\mathrm{N}$ treatment, cutting management and year on annual herbage accumulation and CP yield.

\section{Treatment}

$\mathbf{N}$ application

none
medium
high
Significance $^{\dagger}$
none vs. medium and high
medium vs. high

\section{Cutting management}

$2.5 \mathrm{~cm}$

3740

2765

3122

3069

NS

NS

NS
CP yield $\mathrm{kg} \mathrm{ha}^{-1} \mathrm{yr}^{-1}$

2560

648

2655

470

$7.6 \mathrm{~cm}$

Significance

$2.5 \mathrm{~cm}$ vs. 5.1 and $7.6 \mathrm{~cm}$

$5.1 \mathrm{~cm}$ vs. $7.6 \mathrm{~cm}$

500

575

569

NS

NS

NS

*** $* *$

$* * * \quad * * *$

NS NS

$1962 \quad 343$

4009753

Significance

1999

***

***

†Significance of $\mathrm{F}$ test. NS, non-significant $*, \mathrm{P}<0.05$; ** $\mathrm{P}<0.01$; *** $\mathrm{P}<0.0001$.

Note: For herbage accumulation:

-Cutting management $\mathrm{x}$ year was significant at $\mathrm{P}<0.05$.

For $\mathrm{CP}$ yield:

$-\mathrm{N} x$ cutting management was significant for $\mathrm{P}<0.01$.

$-\mathrm{Nx}$ year was significant at $\mathrm{P}<0.05$.

$-\mathrm{N} x$ cutting management $\mathrm{x}$ year was significant for $\mathrm{P}<0.01$. 


\section{Crude protein concentration}

Although $\mathrm{N}$ application was not found to significantly affect $\mathrm{CP}$ concentration in forage, a significant $(\mathrm{P}<0.05)$ difference was found between the $\mathrm{CP}$ in plants treated with no $\mathrm{N}$ compared to those treated with the medium and high $\mathrm{N}$ levels. At the no $\mathrm{N}$ treatment level, plants had an average of $17.6 \% \mathrm{CP}$. However, in plants to which medium and high levels of $\mathrm{N}$ were applied, CP levels were $18.5 \%$ and $18.7 \%$, respectively (Table 6 and Appendix Table B). A significant $(\mathrm{P}<0.01)$ interaction between $\mathrm{N}$ treatment and year showed that the difference between $\mathrm{N}$ treatments was only found in 1999 (Fig. 3). An interaction $(\mathrm{P}<0.01)$ between $\mathrm{N}$ treatment, cutting management and year was found (Fig. 4). Crude protein concentration of herbage was higher for all $\mathrm{N}$ treatments and cutting managements in 2000, compared to 1999, except the medium $\mathrm{N}$ and $2.5 \mathrm{~cm}$ cut and the high $\mathrm{N}$ and $2.5 \mathrm{~cm}$ cut.

In 2000, a significant $(\mathrm{P}<0.05)$ interaction between $\mathrm{N}$ application and harvest period was found for $\mathrm{CP}$ concentration (Fig. 5). Crude protein was highest in harvest period 3 for plants that were treated with the no $\mathrm{N}$ and the high $\mathrm{N}$ level. Plants treated with the medium level of $\mathrm{N}$ had the greatest $\mathrm{CP}$ in period 2. For plants at each level of $\mathrm{N}$, the lowest $\mathrm{CP}$ was found when they were harvested in period 1 . An N, cutting management and harvest period interaction was also found $(\mathrm{P}<0.05)$ in 2000.

Cutting management significantly $(\mathrm{P}<0.01)$ affected the $\mathrm{CP}$ concentration in herbage (Table 6 and Appendix Table B). Crude protein of forage cut at $2.5 \mathrm{~cm}$ was significantly less $(\mathrm{P}<0.01)$ than forage cut at 5.1 and $7.6 \mathrm{~cm}$. Also, the herbage cut to $5.1 \mathrm{~cm}$ cutting treatment had lower $\mathrm{CP}$ concentrations $(\mathrm{P}<0.05)$ than the herbage cut to 
Table 6: Effect of $\mathrm{N}$ treatment, cutting management, harvest period and year on $\mathrm{CP}$, NDF and ADF concentrations in herbage.

\begin{tabular}{lccc}
\hline Treatment & CP & NDF & ADF \\
\hline N application & $------------1 \%---------$ & \\
none & & & \\
medium & 17.6 & 56.5 & 28.4 \\
high & 18.5 & 56.8 & 28.2 \\
Significance & 18.7 & 56.6 & 27.3 \\
none vs. medium and high & NS & NS & NS \\
medium vs. high & $*$ & NS & NS \\
& NS & NS & NS
\end{tabular}

\section{Cutting management}

$\begin{array}{lccc}2.5 \mathrm{~cm} & 17.3 & 57.8 & 30.0 \\ 5.1 \mathrm{~cm} & 18.2 & 57.3 & 27.8 \\ 7.6 \mathrm{~cm} & 19.4 & 54.7 & 26.2 \\ \text { ance } & * * & * * * & * * * \\ \text { s. } 5.1 \text { and } 7.6 \mathrm{~cm} & * * & * * * & * * * \\ \text { s. } 7.6 \mathrm{~cm} & * & * * & * *\end{array}$

\section{Harvest period ${ }^{1}$}

Significance

$2.5 \mathrm{~cm}$ vs. 5.1 and $7.6 \mathrm{~cm}$

$5.1 \mathrm{~cm}$ vs. $7.6 \mathrm{~cm}$

1

2

3

17.6

52.0

24.2

19.8

57.2

31.2

20.5

55.3

34.0

Significance

$* * *$

period 1 vs. periods 2 and 3

$* * *$

$* * *$

$* * *$

period 2 vs. period 3

$* *$

$* * *$

$* * *$

$* * * \quad * * *$

Year

\begin{tabular}{rlll}
1999 & 17.4 & 58.4 & 26.8 \\
2000 & 19.2 & 54.8 & 29.1 \\
Significance & $* * *$ & $* * *$ & $* * *$ \\
\hline
\end{tabular}

${ }^{1}$ Harvest period was analyzed for 2000 only.

†Significance of $\mathrm{F}$ test. NS, non-significant; *, $\mathrm{P}<0.05 ; * * \mathrm{P}<0.01$; *** $\mathrm{P}<0.0001$.

Note: For CP:

$-\mathrm{N} x$ harvest period and $\mathrm{N} x$ cutting management $\mathrm{x}$ harvest period were significant at $\mathrm{P}<0.05$.

$-\mathrm{N} x$ year, cutting management $\mathrm{x}$ year and $\mathrm{N} x$ cutting management $\mathrm{x}$ year were significant at $\mathrm{P}<0.01$.

For NDF:

-Cutting management $\mathrm{x}$ harvest period was significant at $\mathrm{P}<0.0001$.

-Cutting management $\mathrm{x}$ year was significant at $\mathrm{P}<0.01$.

-Cutting management $\mathrm{x}$ harvest period and $\mathrm{N} x$ cutting management $\mathrm{x}$ harvest period was For ADF: significant at $\mathrm{P}<0.0001$.

$-\mathrm{N} x$ year and cutting management $\mathrm{x}$ year interactions were significant at $\mathrm{P}<0.01$.

-Cutting management $\mathrm{x}$ harvest period interaction was significant for $\mathrm{P}<0.0001$. 


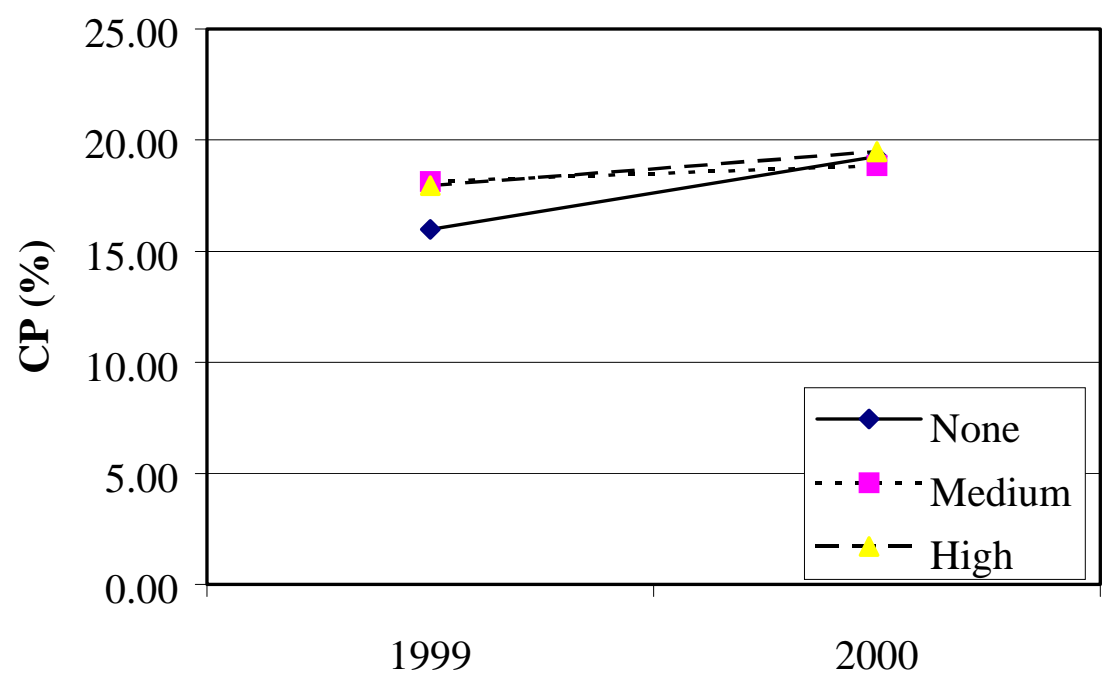

Year

Figure 3: Effect of year and $\mathrm{N}$ treatment on $\mathrm{CP}$ concentration in herbage. Nitrogen was applied two times each year. The interaction of year and $\mathrm{N}$ treatment was significant at $\mathrm{P}$ $<0.01$. Year was significant at $\mathrm{P}<0.0001$, and $\mathrm{N}$ was NS. The orthogonal comparison of no $\mathrm{N}$ vs. medium and high $\mathrm{N}$ was significant at $\mathrm{P}<0.05$.

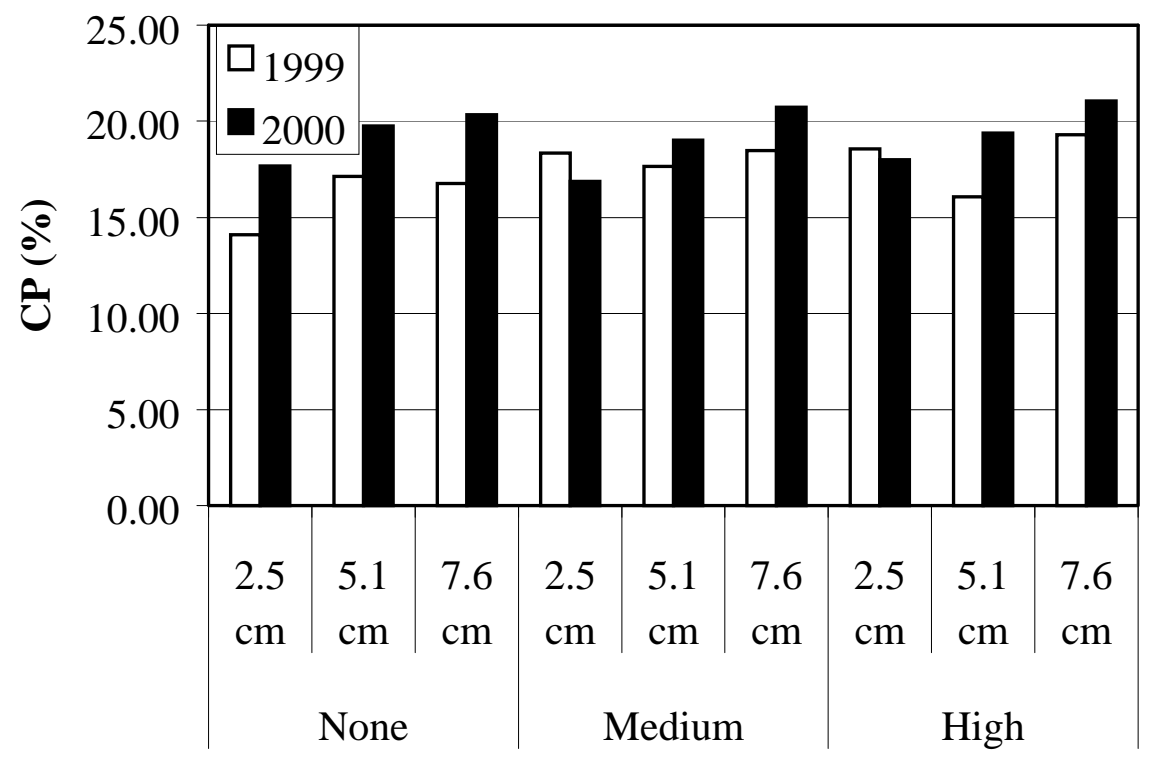

Treatments ( $\mathbf{N}$ and cutting management)

Figure 4: Effect of $\mathrm{N}$ treatment, cutting management and year on $\mathrm{CP}$ concentration in herbage. The interaction between $\mathrm{N}$ treatment, cutting management and year was significant at $\mathrm{P}<0.05$. Nitrogen was NS, but the orthogonal comparison of no $\mathrm{N}$ vs. medium and high $\mathrm{N}$ was significant at $\mathrm{P}<0.05$. Cutting management was significant at $\mathrm{P}<0.01$, and year was significant at $\mathrm{P}<0.0001$. 


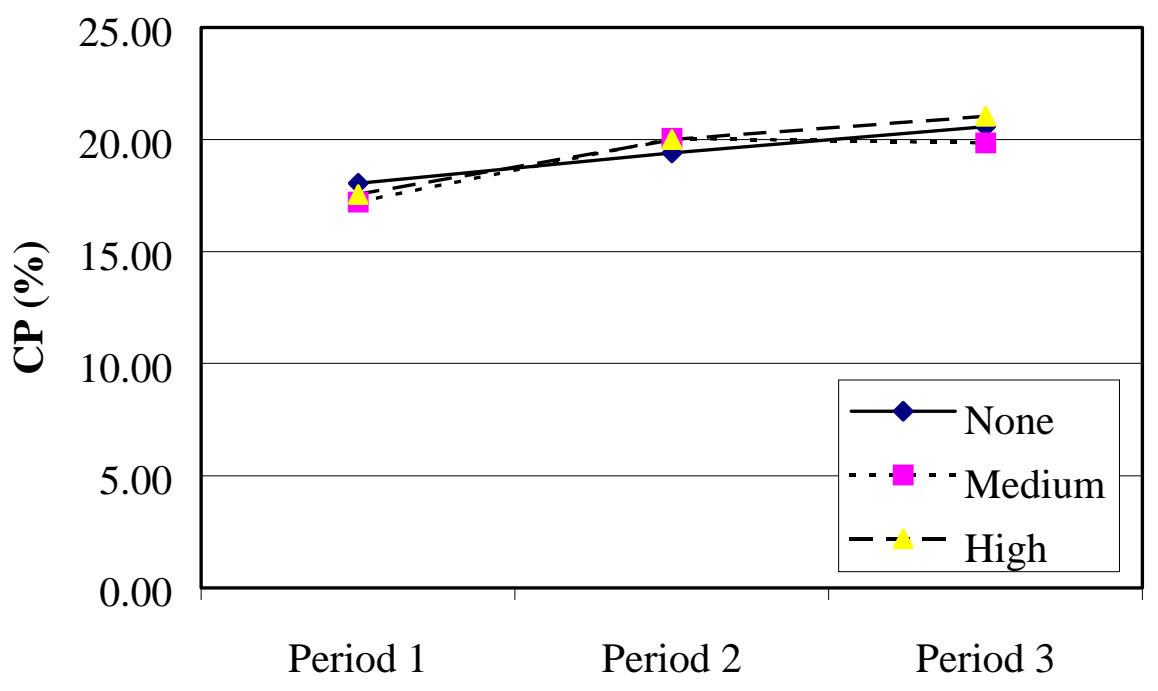

\section{Harvest period}

Figure 5: Effect of harvest period and $\mathrm{N}$ treatment on $\mathrm{CP}$ concentration in herbage harvested in 2000. The interaction between harvest period and $\mathrm{N}$ treatment was significant at $\mathrm{P}<0.05$. Harvest period was significant at $\mathrm{P}<0.0001$. Nitrogen was NS, but the orthogonal comparison of no $\mathrm{N}$ vs. medium and high $\mathrm{N}$ was significant at $\mathrm{P}<$ 0.05 .

$7.6 \mathrm{~cm}$. Crude protein values for the herbage cut at the $2.5,5.1$ and $7.6 \mathrm{~cm}$ levels were $17.3 \%, 18.2 \%$ and $19.4 \%$, respectively.

A significant $(\mathrm{P}<0.01)$ interaction was found between cutting management and year (Fig. 6). Herbage harvested in 2000 had the highest CP. However, the CP values of herbage cut to $2.5 \mathrm{~cm}$ were very similar each year. An interaction between cutting management and harvest period was also found $(\mathrm{P}<0.0001)$ in 2000 (Fig. 7). Crude protein was greatest for herbage harvested at the 5.1 and $7.6 \mathrm{~cm}$ management in period 3 . Herbage harvested at the $7.6 \mathrm{~cm}$ management contained the highest $\mathrm{CP}$ in harvest period 2. The lowest $\mathrm{CP}$ concentrations for each cutting management were found in herbage harvested in period 1 . 


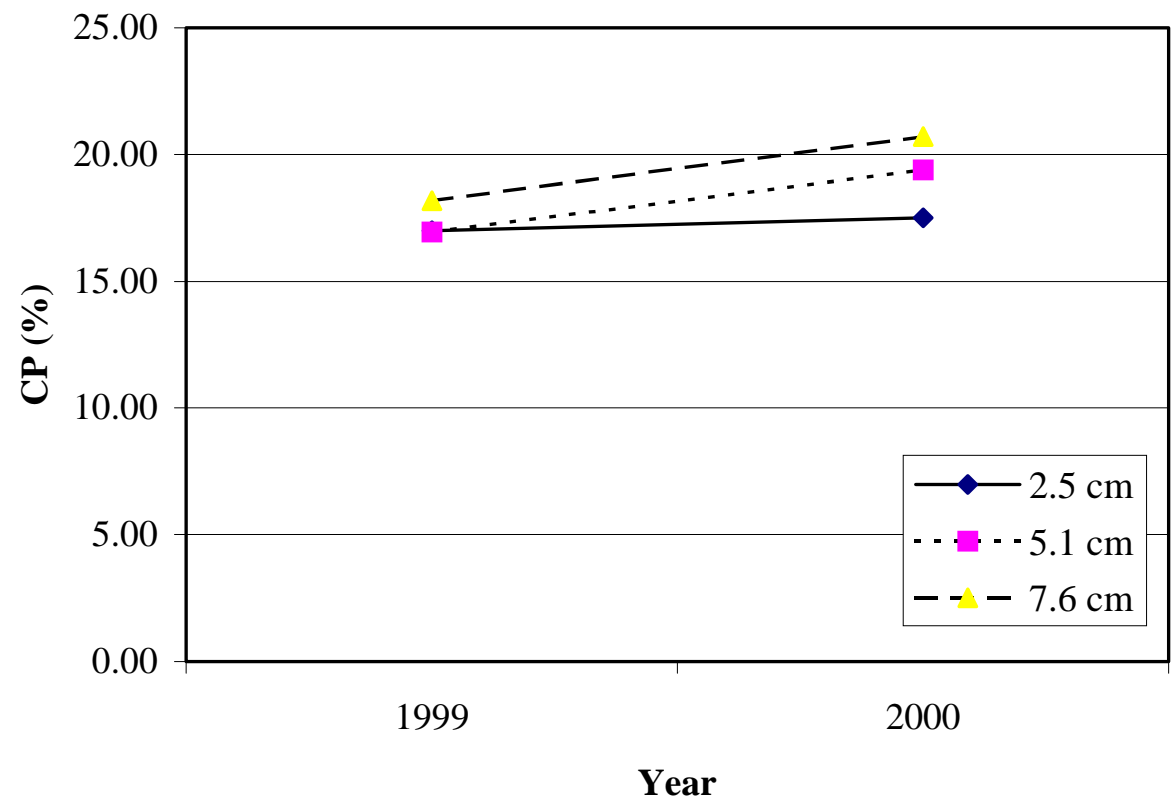

Figure 6: Effect of year and cutting management on $\mathrm{CP}$ concentration in herbage. The interaction between year and cutting management was significant at $P<0.01$. Year was significant at $\mathrm{P}<0.0001$, and cutting management was significant at $\mathrm{P}<0.01$.

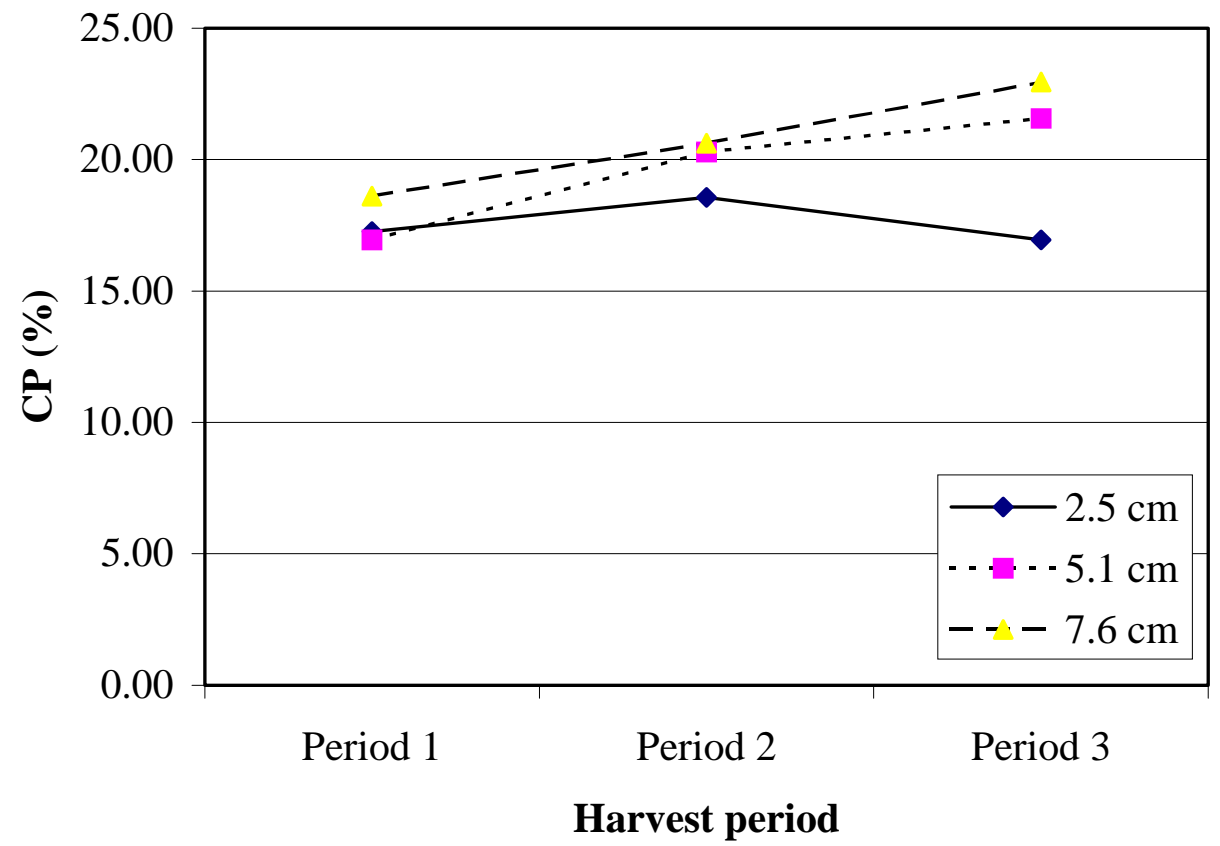

Figure 7: Effect of harvest period and cutting management on $\mathrm{CP}$ concentration in herbage harvested in 2000. The interaction was significant at $P<0.0001$. Harvest period was significant at $\mathrm{P}<0.0001$, and cutting management was significant at $\mathrm{P}<0.01$. 
In 2000, the effect of harvest period on the concentration of $\mathrm{CP}$ in the forage was highly significant $(\mathrm{P}<0.0001)$ (Table 6 and Appendix Table $\mathrm{C}$ ). Herbage harvested in period 1 had an average $\mathrm{CP}$ content of $17.6 \%$. The orthogonal contrast showed that this was less $(\mathrm{P}<0.0001)$ than the $\mathrm{CP}$ concentration of herbage harvested in periods 2 (19.8\%) and $3(20.5 \%)$. In addition, the CP content of herbage harvested in period 2 was $(\mathrm{P}<0.01)$ lower than herbage harvested in period 3.

Crude protein concentration of herbage was significantly $(\mathrm{P}<0.0001)$ affected by year (Table 6 and Appendix Table B). Herbage harvested in 2000 had a CP content of 19.2\%, while herbage harvested in 1999 had a CP content of only $17.4 \%$.

\section{Crude protein yield}

The amount of $\mathrm{CP}$ harvested was not significantly affected by $\mathrm{N}$ treatments (Table 5 and Appendix Table $\mathrm{D})$. However, an interaction $(\mathrm{P}<0.05)$ between $\mathrm{N}$ and year was found (Fig. 8), which showed that $\mathrm{CP}$ yield of the no $\mathrm{N}$ treatment was less that that of the other two $\mathrm{N}$ treatments in 1999. A significant $(\mathrm{P}<0.01)$ interaction between $\mathrm{N}$, cutting management and year was also found.

Cutting management significantly $(\mathrm{P}<0.01)$ affected the amount of $\mathrm{CP}$ harvested (Table 5 and Appendix Table D). The $2.5 \mathrm{~cm}$ cutting management resulted in significantly $(\mathrm{P}<0.0001)$ greater $\mathrm{CP}$ harvested compared to the 5.1 and $7.6 \mathrm{~cm}$ cutting managements. The average amounts of $\mathrm{CP}$ removed for the $2.5,5.1$ and $7.6 \mathrm{~cm}$ cutting levels were $648 \mathrm{~kg} \mathrm{ha}^{-1}, 470 \mathrm{~kg} \mathrm{ha}^{-1}$ and $526 \mathrm{~kg} \mathrm{ha}^{-1}$, respectively. 


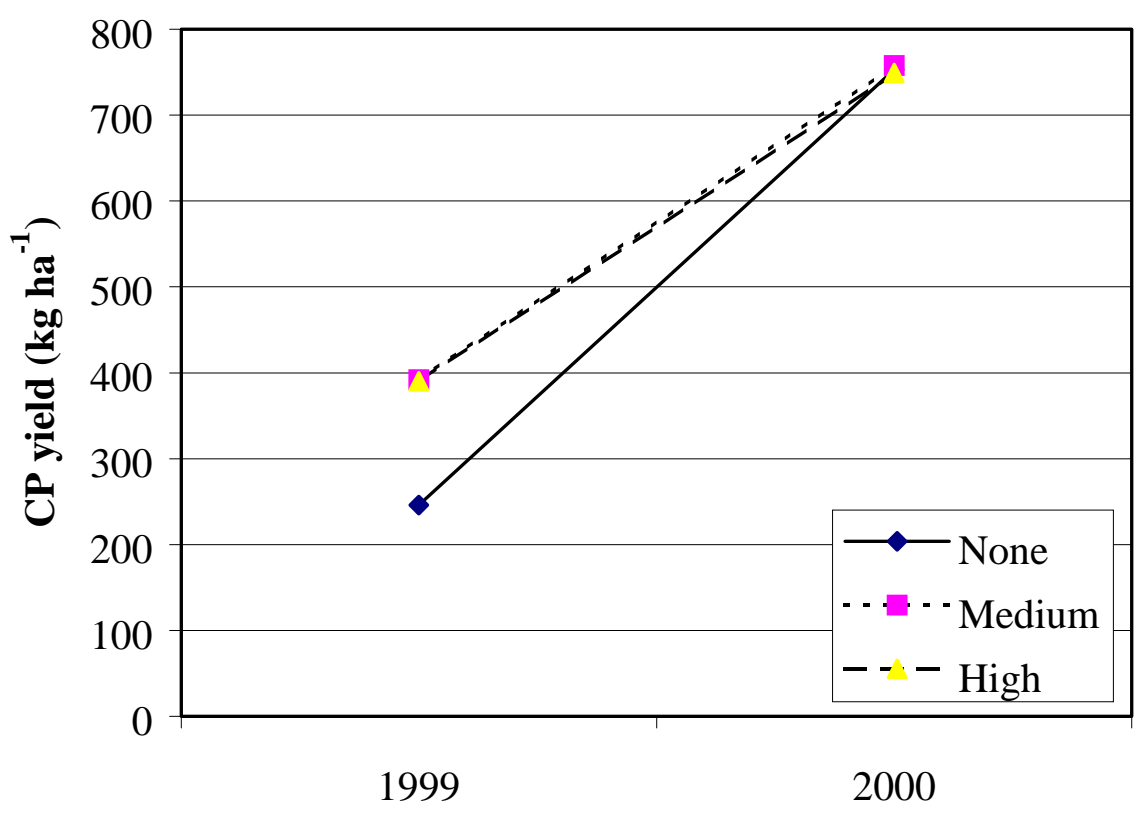

Year

Figure 8: Effect of year and $\mathrm{N}$ treatments on $\mathrm{CP}$ yield. The interaction between year and $\mathrm{N}$ treatments was significant at $\mathrm{P}<0.05$. Year was significant at $\mathrm{P}<0.0001$, and cutting management was significant at $\mathrm{P}<0.01$.

In 2000, harvest period did significantly affected CP yields $(\mathrm{P}<0.01)$ (Table 5 and Appendix Table E). In addition the amount of $\mathrm{CP}$ harvested was greater in period 1 than in periods 2 and 3 when herbage was cut to 5.1 or $7.6 \mathrm{~cm}$. Herbage had the greatest CP yield in harvest period 2, being much lower in period 1 .

Year was found to significantly $(\mathrm{P}<0.0001)$ affect the amount of $\mathrm{CP}$ harvested. The CP harvested in $2000\left(753 \mathrm{~kg} \mathrm{ha}^{-1} \mathrm{yr}^{-1}\right)$ was more than double the amount harvested in 1999 (343 $\left.\mathrm{kg} \mathrm{ha}^{-1} \mathrm{yr}^{-1}\right)$ (Table 5 and Appendix Table D).

\section{Neutral detergent fiber}

Nitrogen treatments did not significantly affect NDF concentration in the forage harvested (Table 6 and Appendix Table F). There was an interaction $(\mathrm{P}<0.0001)$ between N, cutting management and harvest period, but only in 2000 . 
Cutting management significantly $(\mathrm{P}<0.0001)$ affected the concentration of NDF in the harvested herbage (Table 6 and Appendix Table F). Herbage mowed to a height of $2.5 \mathrm{~cm}$ had a higher $(\mathrm{P}<0.0001)$ concentration of NDF than herbage mowed to 5.1 and $7.6 \mathrm{~cm}$. Also, herbage cut to $5.1 \mathrm{~cm}$ had more $(\mathrm{P}<0.01) \mathrm{NDF}$ than the $7.6 \mathrm{~cm}$ treatment. The average percent NDF for the 2.5, 5.1 and $7.6 \mathrm{~cm}$ cutting treatments were: $57.8 \%$, $57.3 \%$ and $54.7 \%$, respectively.

In 2000, an interaction $(\mathrm{P}<0.0001)$ between cutting management and harvest period was found (Fig. 9). The NDF concentration of herbage cut to 5.1 or $7.6 \mathrm{~cm}$ was greatest in harvest period 2; however, for the 2.5 cutting management NDF concentration was greatest for herbage harvested in period 3. There was also an interaction $(\mathrm{P}<0.01)$ between cutting management and year (Fig. 10). Highest NDF concentration in 1999 was for herbage cut to 5.1, but in 2000 herbage cut to $7.6 \mathrm{~cm}$ had the highest NDF concentration.

In 2000, herbage harvested in period 1 had lower NDF concentrations $(\mathrm{P}<$ 0.0001) than herbage harvested in periods 2 and 3 (Table 6 and Appendix Table G). The NDF content of herbage harvested in period 2 was greater $(\mathrm{P}<0.05)$ than herbage harvested in period 3. Year also significantly $(\mathrm{P}<0.0001)$ affected the NDF in the harvested herbage (Table 6). Herbage harvested in 1999 had higher NDF concentrations (58.4\%) than herbage harvested in $2000(54.8 \%)$. 


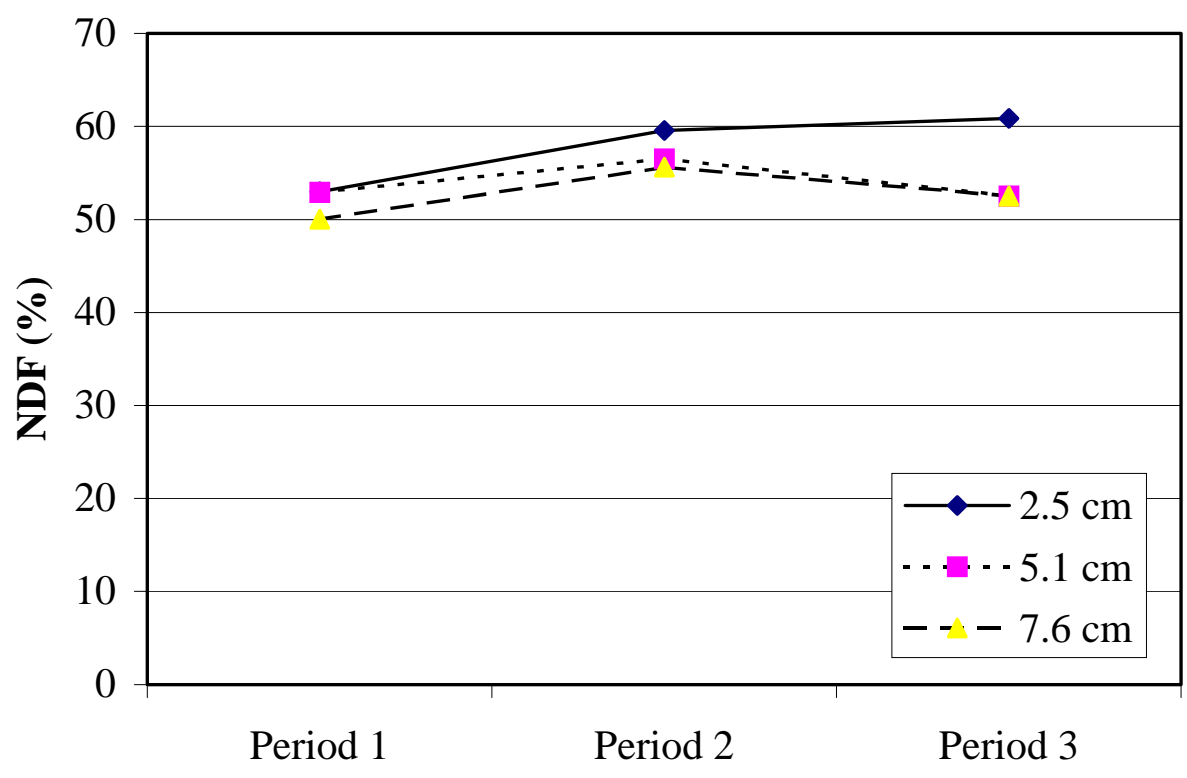

Harvest period

Figure 9: Effect of harvest period and cutting management on NDF concentration in herbage harvested in 2000. The interaction between harvest period and cutting management was significant at $\mathrm{P}<0.0001$. Harvest period and cutting management were significant at $\mathrm{P}<0.0001$.

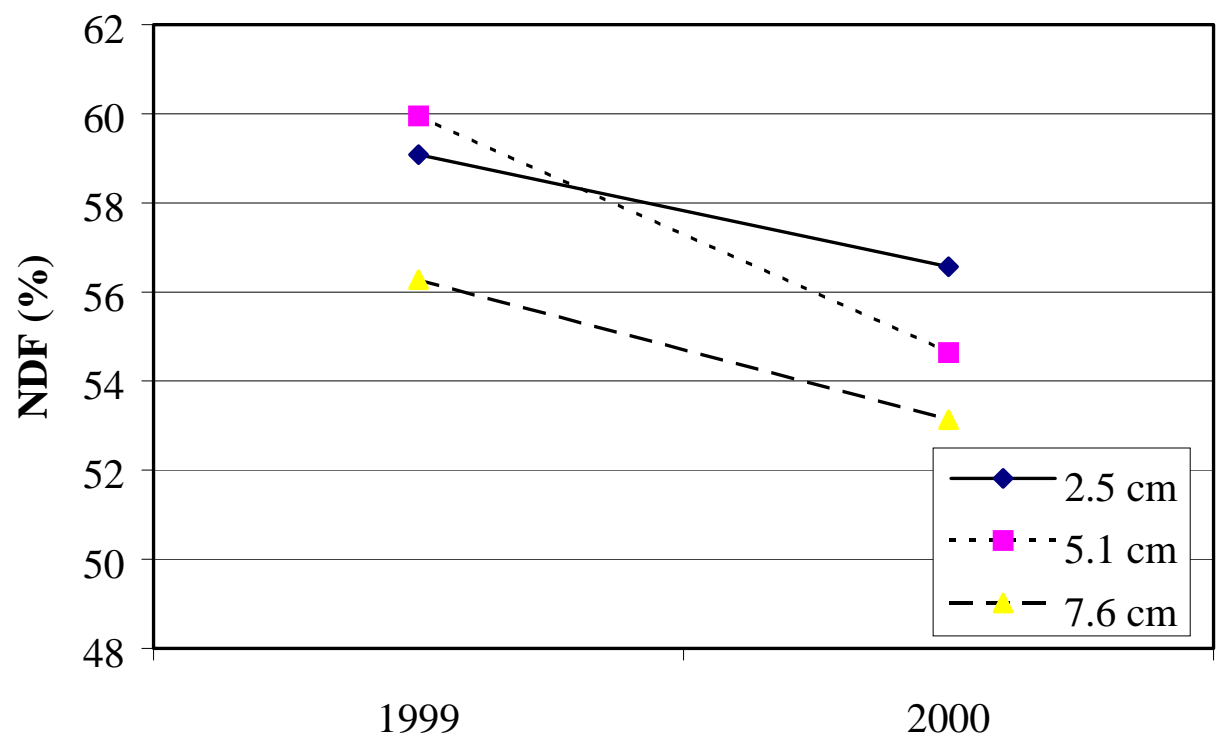

Year

Figure 10: Effect of year and cutting management on NDF concentration in herbage. The interaction between year and cutting management was significant at $\mathrm{P}<0.01$. Year and cutting management were significant at $\mathrm{P}<0.0001$. 


\section{Acid detergent fiber}

As with NDF, $\mathrm{N}$ treatments did not affect the ADF concentration of herbage (Table 6 and Appendix Table F). However, the significant $\mathrm{N}$ treatment and year interaction $(\mathrm{P}<0.01)$ (Fig. 11) indicated that $\mathrm{N}$ treatment reduced ADF concentration in 1999, but not in 2000. Also in 2000, there was an $\mathrm{N}$ treatment, cutting management and harvest period interaction.

Cutting management significantly $(\mathrm{P}<0.0001)$ affected the concentration of ADF in the herbage that was harvested (Table 6 and Appendix Table F). Herbage mowed to a height of $2.5 \mathrm{~cm}$ had a greater $(\mathrm{P}<0.0001)$ ADF content than herbage mowed to 5.1 or $7.6 \mathrm{~cm}$. Also, the herbage cut to $5.1 \mathrm{~cm}$ had higher $(\mathrm{P}<0.01)$ ADF concentrations than herbage cut to $7.6 \mathrm{~cm}$. The average percent NDF for the $2.5,5.1$ and $7.6 \mathrm{~cm}$ cutting treatments were: $30.0 \%, 27.8 \%$ and $26.2 \%$, respectively. In 2000 , herbage harvested at each cutting level had higher ADF percentages than in year 1999, although a significant ( $\mathrm{P}<0.01)$ interaction between cutting management and year was found (Fig. 12).

Harvest period significantly $(\mathrm{P}<0.0001)$ affected the ADF content in herbage in 2000 (Table 6 and Appendix Table G). Herbage harvested in period 1 had lower ADF (24.2\%) than herbage harvested in periods $2(31.2 \%)$ and 3 (34.0\%). Also, ADF concentrations of herbage harvested in period 2 were lower $(\mathrm{P}<0.0001)$ than period 3. Differences between periods could only be analyzed for the year 2000. A cutting management and harvest period interaction was found ( $\mathrm{P}$ < 0.0001) (Fig. 13) in 2000. Herbage ADF concentration increased during 2000 at each period in the order 7.6, 5.1 and $2.5 \mathrm{~cm}$ cutting managements. However, the differences were not all significant.

Herbage harvested in 2000 had significantly $(\mathrm{P}<0.0001)$ greater ADF concentration (29.1\%) than herbage harvested in 1999 (26.8\%). 


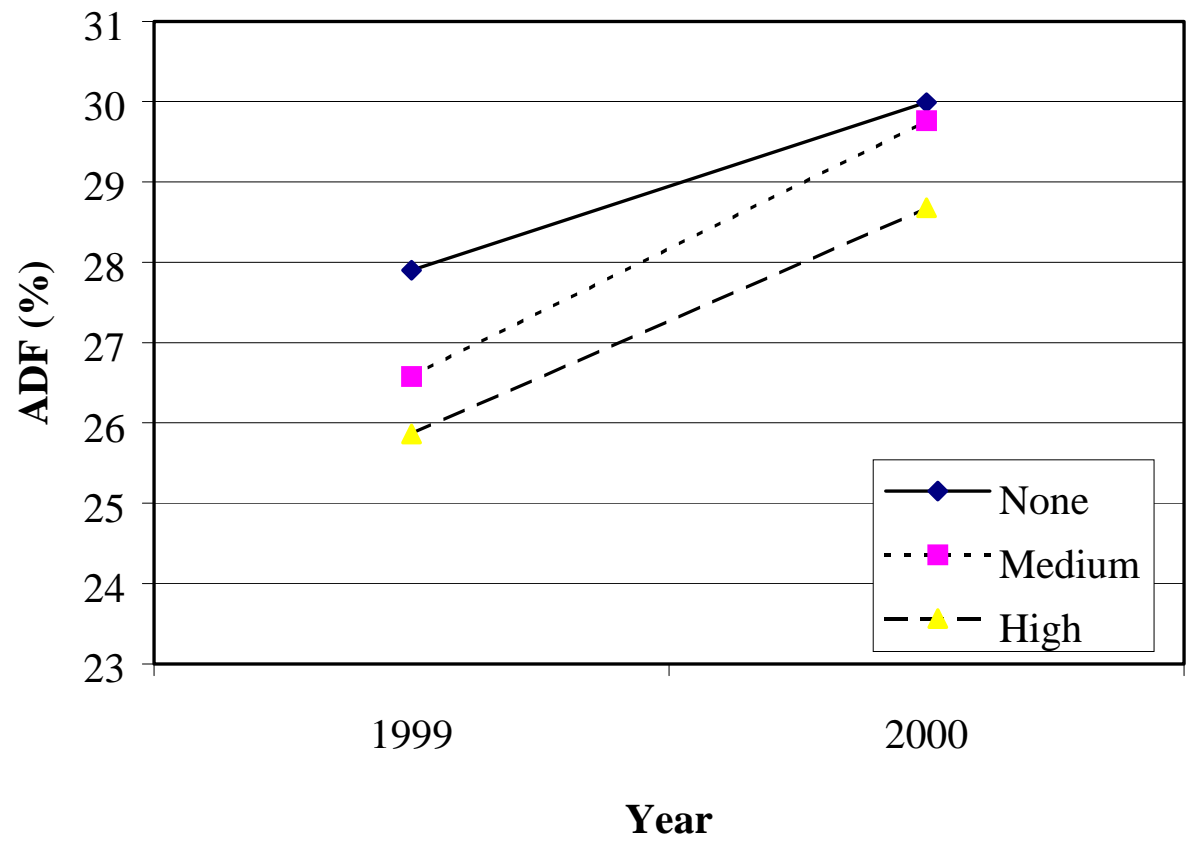

Figure 11: Effect of year and $N$ treatment on ADF concentration herbage. The interaction between year and $\mathrm{N}$ treatment was significant at $\mathrm{P}<0.01$. Year was significant at $\mathrm{P}<0.0001$, and $\mathrm{N}$ was $\mathrm{NS}$.

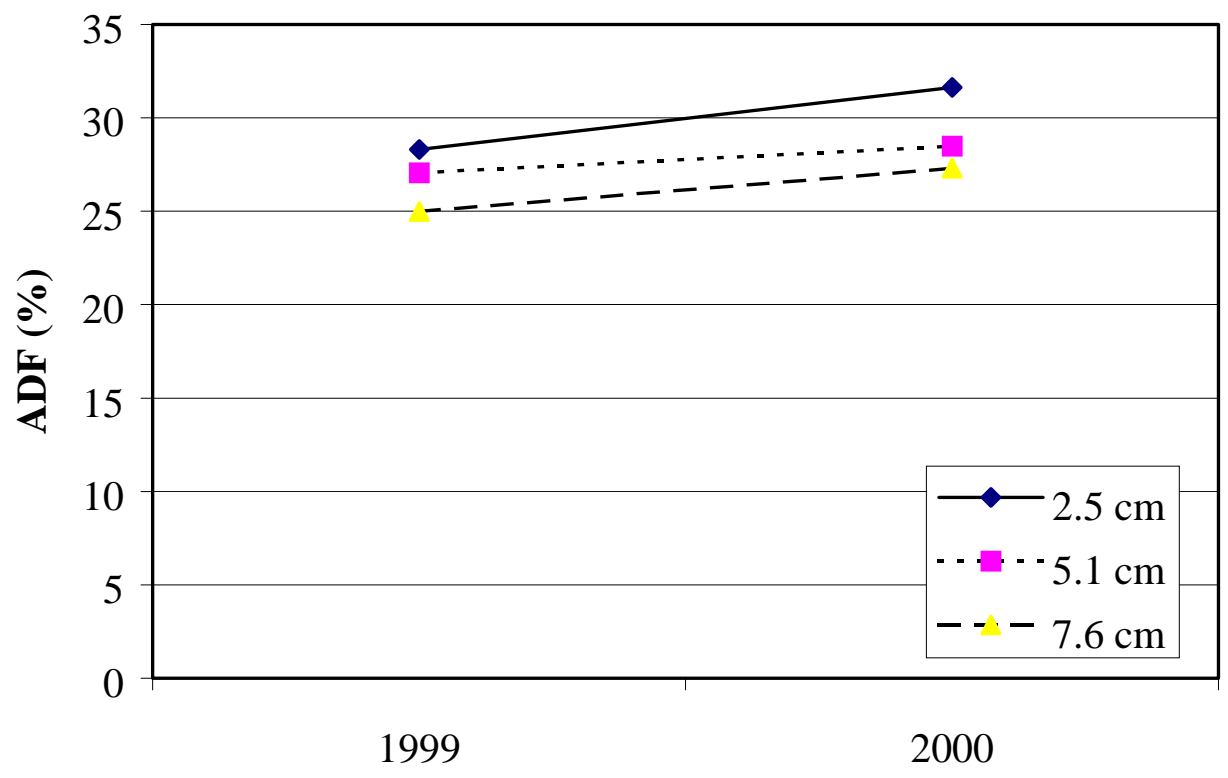

Year

Figure 12: Effect of year and cutting management on ADF concentration herbage. The interaction between year and cutting management was significant at $\mathrm{P}<0.01$. Year and cutting management were significant at $\mathrm{P}<0.0001$. 


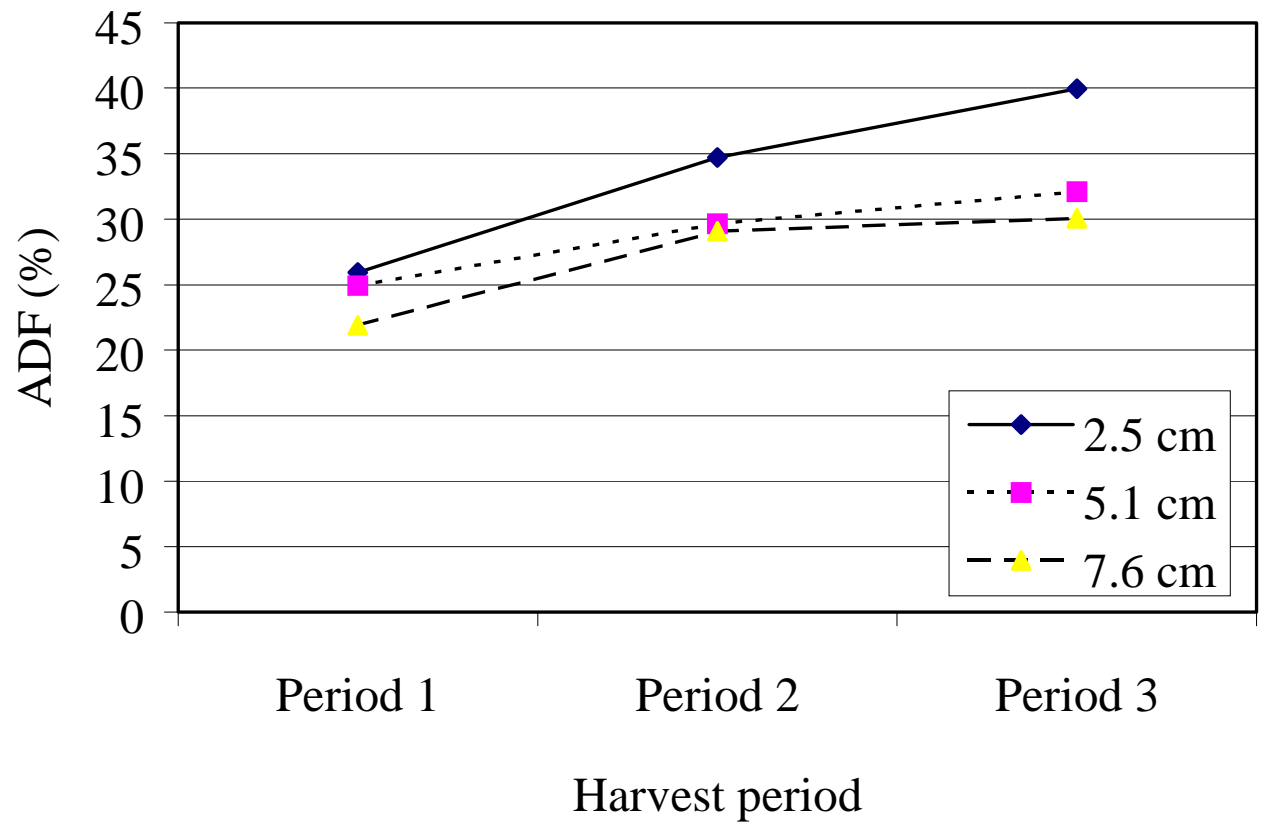

Figure 13: Effect of harvest period and cutting management on ADF concentration oinherbage harvested in 2000. The interaction between harvest period and cutting management was significant at $\mathrm{P}<0.0001$. Harvest period and cutting management were significant at $\mathrm{P}<0.0001$.

\section{Pasture Root Growth}

\section{Root volume}

Since root volume in the top sampling depth was about 4 times greater than at the lower sampling depths, these results will be emphasized. Roots at the $0.0-5.1 \mathrm{~cm}$ depth had much greater $(\mathrm{P}<0.0001)$ root volume than the other depths (Table 7). A significant difference $(\mathrm{P}<0.0001)$ was also found between the $5.1-10.2 \mathrm{~cm}$ and $10.2-20.3 \mathrm{~cm}$ depths. Root volumes in the $5.1-10.2 \mathrm{~cm}$ depth were greater compared to the $10.2-$ $20.3 \mathrm{~cm}$ depth. There were interactions between depth of sampling and other sources of variation.

Root volume was significantly higher $(\mathrm{P}<0.01)$ at the medium and high $\mathrm{N}$ application levels, as compared to no $\mathrm{N}$ (Table 7 and Appendix Table H). However, this 
was only true for the $0.0-5.1 \mathrm{~cm}$ sample depth, as evidenced by the $\mathrm{N}$ and depth interaction $(\mathrm{P}<0.01)$ (Fig. 14).

When plants were cut to $2.5 \mathrm{~cm}$, root volume at the $0.0-5.1 \mathrm{~cm}$ depth was significantly lower $(\mathrm{P}<0.01)$ than those cut to 5.1 or $7.6 \mathrm{~cm}$ (Table 7 and Appendix Table H). Cutting management did not significantly affect root volume in the lower sampling depths, resulting in a cutting management and sampling depth interaction $(\mathrm{P}<$ 0.05) (Fig. 15).

Sampling date greatly affected root volume $(\mathrm{P}<0.0001)$ (Table 7 and Appendix Table H). At each of the three cutting managements, root volume at the $0.0-5.1 \mathrm{~cm}$ depth was greatest for roots sampled on May 30, 2000. Compared to the root volumes in 2000, the root volumes for roots in 1999 were much lower $(\mathrm{P}<0.0001)$ at the $0.0-5.1$ cm depth. Roots sampled on April 15, 1999, the pre-treatment sample, had significantly less root volume at the $0.0-5.1 \mathrm{~cm}(\mathrm{P}<0.05)$ and $10.2-20.3 \mathrm{~cm}(\mathrm{P}<0.01)$ depths than the post-treatment samples. Roots at the $10.2-20.3 \mathrm{~cm}$ depth, sampled on September 22, 1999 compared to those sampled on May 27 and October 25, 1999 reveal root volumes at the latter two dates that were significantly greater $(\mathrm{P}<0.01)$. Also, at the 2 lower sampling depths, roots sampled on October 25, 1999 had a much lower (P < 0.0001) volume compared to those sampled on May 27, 1999. May 30, 2000 and October 13, 2000 samples had significantly $(\mathrm{P}<0.05)$ higher root volumes than the August 28, 2000 samples, but only at the $10.2-20.3 \mathrm{~cm}$ depth. Also, roots at all three depths had significantly $(\mathrm{P}<0.0001)$ lower volume on October 13, 2000 compared to May 30, 2000. 


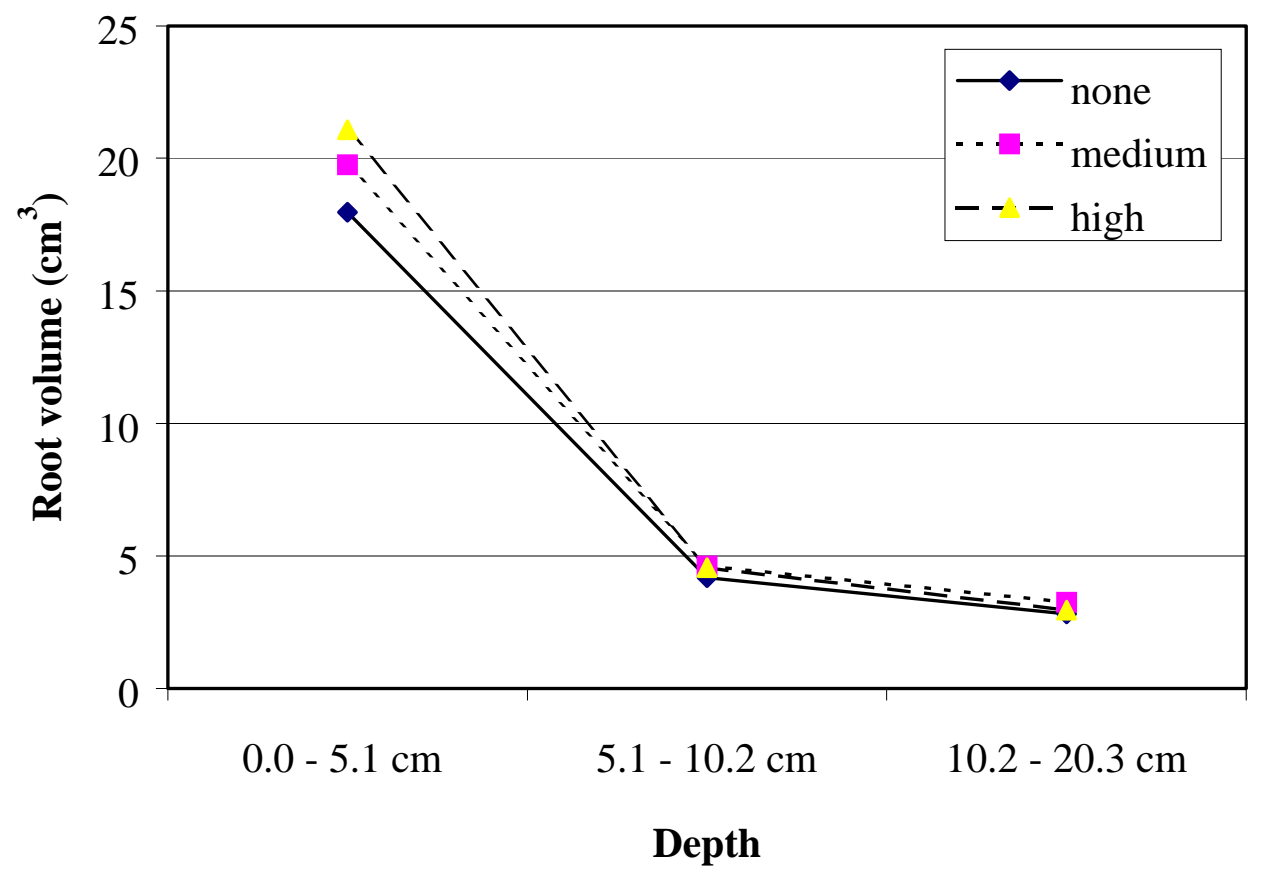

Figure 14: Effect of depth and $\mathrm{N}$ application on root volume. The interaction between depth and $\mathrm{N}$ treatment was significant at $\mathrm{P}<0.01$. Depth was significant at $\mathrm{P}<0.0001$, and $\mathrm{N}$ was significant at $\mathrm{P}<0.05$.

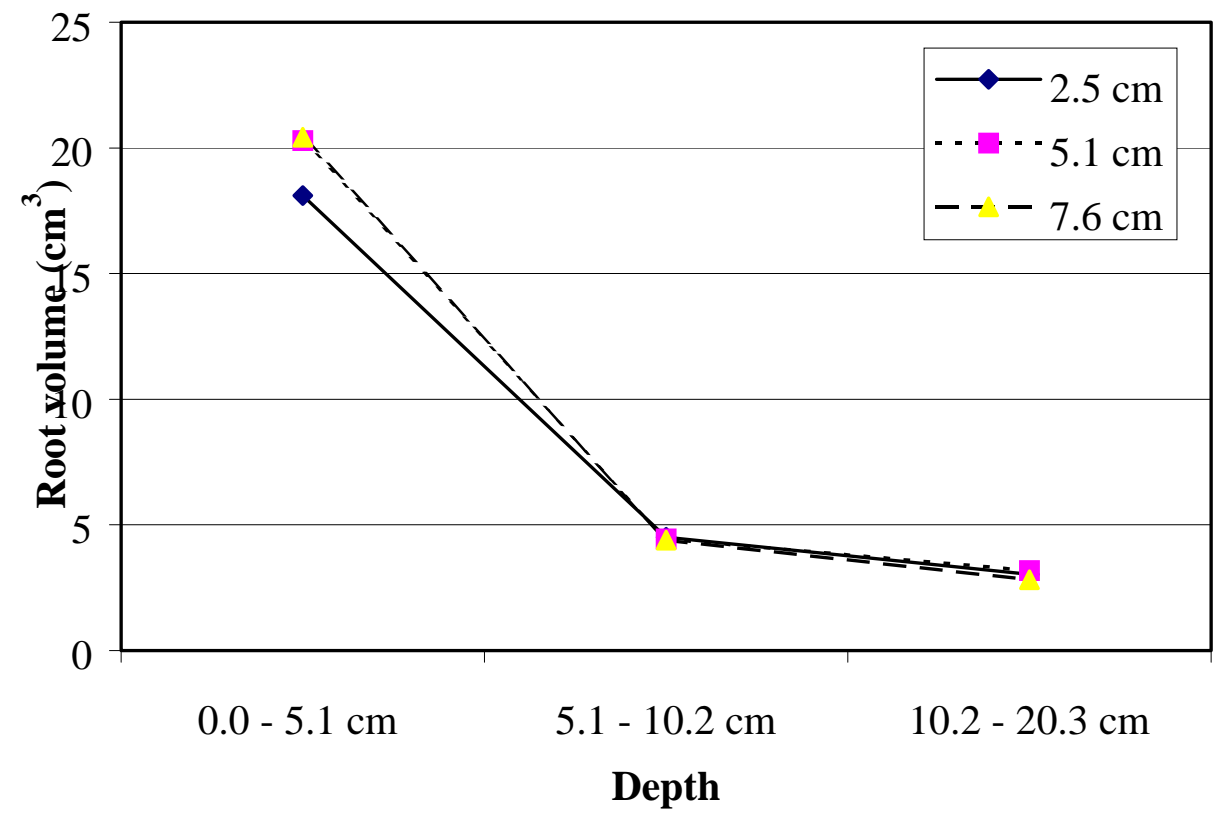

Figure 15: Effect of depth and cutting management on root volume. The interaction between depth and cutting management was significant at $\mathrm{P}<0.01$. Depth was significant at $\mathrm{P}<0.0001$, and cutting management was NS. 
Table 7: Effect of depth, $\mathrm{N}$ treatment, cutting management and sampling date on root volume.

\begin{tabular}{|c|c|c|c|}
\hline \multirow[b]{2}{*}{ Treatment } & \multicolumn{3}{|c|}{ Depth } \\
\hline & $0.0-5.1 \mathrm{~cm}$ & $5.1-10.2 \mathrm{~cm}$ & $10.2-20.3 \mathrm{~cm}$ \\
\hline \multicolumn{4}{|l|}{$\mathrm{N}$ application } \\
\hline none & 18.0 & 4.2 & 2.8 \\
\hline medium & 19.8 & 4.6 & 3.3 \\
\hline high & 21.1 & 4.6 & 3.0 \\
\hline Significance $e^{\dagger}$ & $* *$ & NS & NS \\
\hline none vs. medium and high & $* *$ & NS & NS \\
\hline medium vs. high & NS & NS & NS \\
\hline \multicolumn{4}{|l|}{ Cutting management } \\
\hline $2.5 \mathrm{~cm}$ & 18.1 & 4.5 & 3.0 \\
\hline $5.1 \mathrm{~cm}$ & 20.3 & 4.5 & 3.2 \\
\hline $7.6 \mathrm{~cm}$ & 20.4 & 4.4 & 2.8 \\
\hline Significance & $*$ & NS & NS \\
\hline $2.5 \mathrm{~cm} \mathrm{~s} .5 .1$ and $7.6 \mathrm{~cm}$ & $* *$ & NS & NS \\
\hline $5.1 \mathrm{~cm} \mathrm{vs} .7 .6 \mathrm{~cm}$ & NS & NS & NS \\
\hline \multicolumn{4}{|l|}{ Date } \\
\hline April 15, 1999 & 17.3 & 3.9 & 2.2 \\
\hline May 27, 1999 & 18.5 & 5.7 & 4.6 \\
\hline September 22, 1999 & 17.9 & 4.6 & 2.6 \\
\hline October 25, 1999 & 17.3 & 4.2 & 2.6 \\
\hline May 30, 2000 & 25.6 & 6.1 & 4.0 \\
\hline August 28, 2000 & 21.2 & 3.7 & 2.5 \\
\hline October 13,2000 & 19.5 & 3.0 & 2.5 \\
\hline Significance & $* * *$ & $* * *$ & $* * *$ \\
\hline April 15, 1999 vs. May 27, 1999 to October 13, 2000 & $*$ & NS & $* *$ \\
\hline 1999 vs 2000 & $* * *$ & NS & NS \\
\hline September 22, 1999 vs. May 27 and October 25, 1999 & NS & NS & $* *$ \\
\hline May 27, 1999 vs. October 25, 1999 & NS & $* *$ & $* * *$ \\
\hline August 28, 2000 vs. May 30 and October 13, 2000 & NS & NS & $*$ \\
\hline May 30,2000 vs. October 13,2000 & $* * *$ & $* * *$ & $* *$ \\
\hline
\end{tabular}

†Significance of $\mathrm{F}$ test. NS, non-significant; $* \mathrm{P}<0.05$; ** $\mathrm{P}<0.01$; *** $\mathrm{P}<0.0001$.

Note: There were no significant interactions. 


\section{Root dry weight}

Nitrogen significantly $(\mathrm{P}<0.01)$ affected root dry weight, but only at the $0.0-$ $5.1 \mathrm{~cm}$ depth (Table 8, Appendix Table I and Fig. 16). At this depth, roots treated with the medium and high $\mathrm{N}$ had significantly $(\mathrm{P}<0.01)$ higher root dry weights compared to roots receiving no $\mathrm{N}$. No significant differences in root dry weight were found between the medium and high $\mathrm{N}$ treatments.

Cutting managements did not significantly affect root dry weights. However, a cutting management and depth interaction was present $(\mathrm{P}<0.05)$ (Fig. 17). At the $0.0-$ $5.1 \mathrm{~cm}$ depth significant $(\mathrm{P}<0.05)$ differences in root dry weights were found between herbage cut to $2.5 \mathrm{~cm}$ and herbage cut to 5.1 or $7.6 \mathrm{~cm}$. Plants that were mowed to the $2.5 \mathrm{~cm}$ cutting level had less root dry weight in the top sampling depth than plants mowed to the other heights.

The date on which roots were sampled had a significant effect on root dry weight $(\mathrm{P}<0.0001)$ (Table 8 and Appendix Table I). A sampling date and depth interaction was also present $(\mathrm{P}<0.0001)$. In the $0.0-5.1 \mathrm{~cm}$ depth, root dry matter in the pre-treatment sample, April 15, 1999, was significantly $(\mathrm{P}<0.0001)$ lower than in the post-treatment samples. Also at the upper root depth, the 1999 samples had significantly $(\mathrm{P}<0.01)$ lower root dry weights compared to 2000 .

Roots in the $5.1-10.2 \mathrm{~cm}$ and $10.2-20.3 \mathrm{~cm}$ depths had greater $(\mathrm{P}<0.0001)$ dry weights in the May 27, 1999 samples compared to the October 25, 1999 samples. However, at the $0.0-5.1 \mathrm{~cm}$ depth, root dry weight was less $(\mathrm{P}<0.05)$ for this comparison. Also, in 2000, roots in all depths had significantly $(\mathrm{P}<0.01)$ more root dry weight when sampled on May 30, 2000 than on October 13, 2000. 
Table 8: Effect of depth, $N$ treatment, cutting management and sampling date on root dry weight.

\begin{tabular}{lcccc}
\hline & & \multicolumn{3}{c}{ Depth } \\
\cline { 3 - 5 } Treatment & & $\mathbf{0 . 0} \mathbf{- 5 . 1} \mathbf{~ c m}$ & $\mathbf{5 . 1} \mathbf{- 1 0 . 2} \mathbf{~ c m}$ & $\mathbf{1 0 . 2}-\mathbf{2 0 . 3} \mathbf{~ c m}$ \\
\hline \multirow{2}{*}{ N application } & none & 4.9 & 1.0 & 0.6 \\
& medium & 5.8 & 1.1 & 0.8 \\
& high & 6.1 & 1.1 & 0.7 \\
Significance & & $* *$ & $\mathrm{NS}$ & $\mathrm{NS}$ \\
none vs. medium and high & $* *$ & $\mathrm{NS}$ & $\mathrm{NS}$ \\
medium vs. high & $\mathrm{NS}$ & $\mathrm{NS}$ & $\mathrm{NS}$
\end{tabular}

\section{Cutting management}

Significance ${ }^{\dagger}$

$\begin{array}{lccc}2.5 \mathrm{~cm} & 5.1 & 1.0 & 0.7 \\ 5.1 \mathrm{~cm} & 5.9 & 1.1 & 0.8 \\ 7.6 \mathrm{~cm} & 5.7 & 1.0 & 0.6 \\ & \mathrm{NS} & \mathrm{NS} & \mathrm{NS} \\ & * & \mathrm{NS} & \mathrm{NS} \\ & \mathrm{NS} & \mathrm{NS} & \mathrm{NS}\end{array}$

\section{Date}

$2.5 \mathrm{~cm}$ vs. 5.1 and $7.6 \mathrm{~cm}$

$5.1 \mathrm{~cm}$ vs. $7.6 \mathrm{~cm}$

(ns

April 15, 1999

May 27, 1999

September 22, 1999

October 25, 1999

May 30, 2000

August 28, 2000

October 13, 2000

Significance

April 15, 1999 vs. May 27, 1999 to October 13, 2000

1999 vs 2000

September 22, 1999 vs. May 27 and October 25, 1999

May 27, 1999 vs. October 25, 1999

August 28, 2000 vs. May 30 and October 13, 2000

May 30, 2000 vs. October 13, 2000

$\begin{array}{ccc}4.1 & 1.0 & 0.5 \\ 4.7 & 1.6 & 1.2 \\ 5.8 & 0.9 & 0.5 \\ 5.8 & 0.8 & 0.5 \\ 7.1 & 1.3 & 0.8 \\ 6.0 & 0.8 & 0.7 \\ 5.6 & 0.8 & 0.6 \\ * * * & * * * & * * * \\ * * * & \mathrm{NS} & \mathrm{NS} \\ * * & \mathrm{NS} & \mathrm{NS} \\ \mathrm{NS} & * & * * \\ * & * * * & * * *\end{array}$

NS

$*$

NS

$* *$

$* * *$

NS

†Significance of $\mathrm{F}$ test. NS, non-significant; *, $\mathrm{P}<0.05$; ** $\mathrm{P}<0.01$; *** $\mathrm{P}<0.0001$.

Note: Harvest date $\mathrm{x}$ sampling depth interaction was significant for $\mathrm{P}<0.0001$. 
Similar to root volume (Table 7), the depth of sampling also significantly $(\mathrm{P}<$ 0.0001 ) affected the root dry weights (Table 8). The roots at the $0.0-5.1 \mathrm{~cm}$ depth had a much more dry weight $(5.6 \mathrm{~g})$ than roots at the $5.1-10.2 \mathrm{~cm}(1.0 \mathrm{~g})$ and $10.2-20.3 \mathrm{~cm}$ (0.7 g) depths. The difference between the $5.1-10.2 \mathrm{~cm}$ and the $10.2-20.3 \mathrm{~cm}$ depths was also significant, but only at $\mathrm{P}<0.01$.

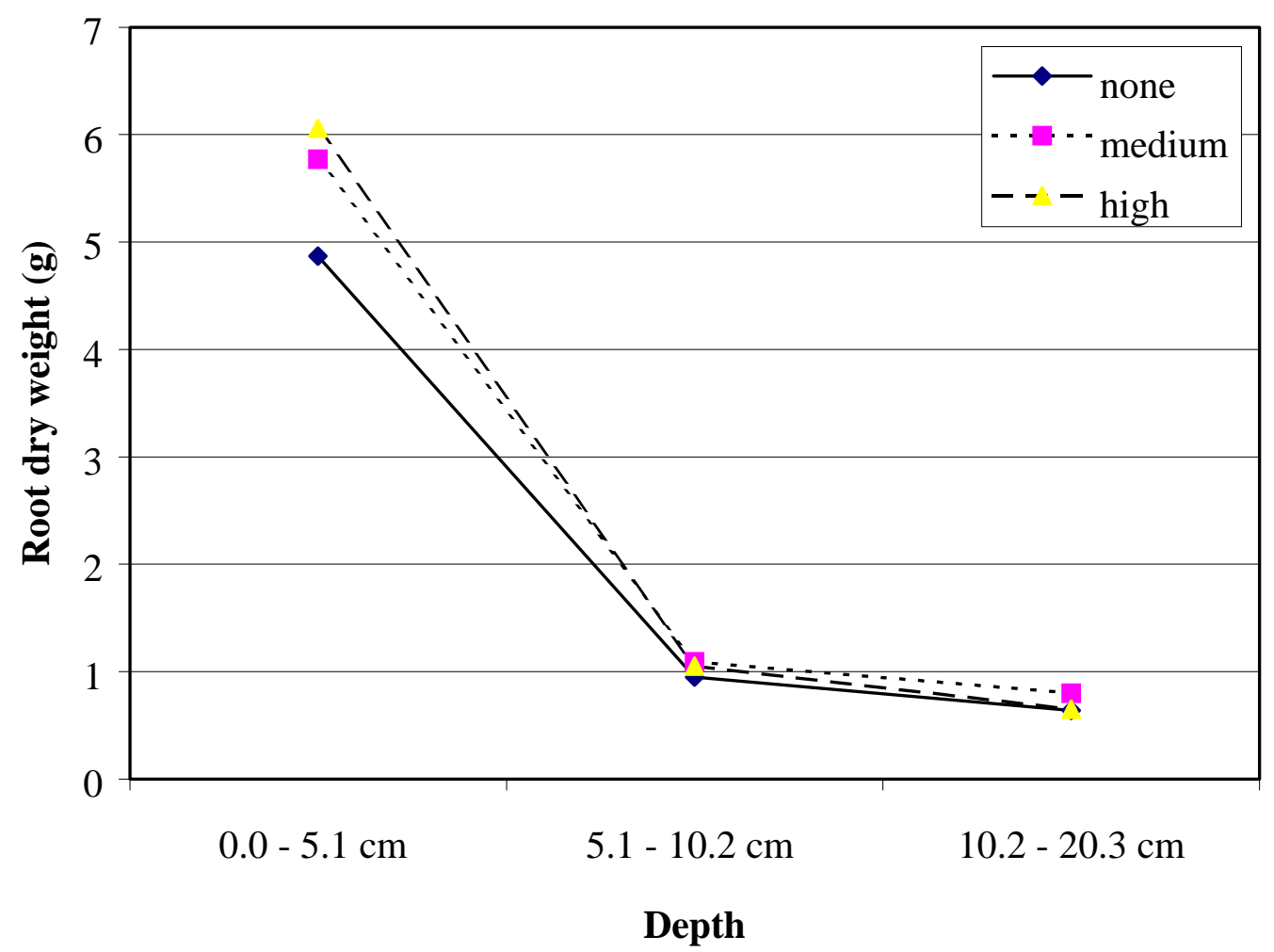

Figure 16: Effect of depth and $N$ treatment on root dry weight. The interaction between depth and $\mathrm{N}$ treatments was significant at $\mathrm{P}<0.01$. Depth was significant at $\mathrm{P}<0.0001$, and $\mathrm{N}$ was significant at $\mathrm{P}<0.05$. 


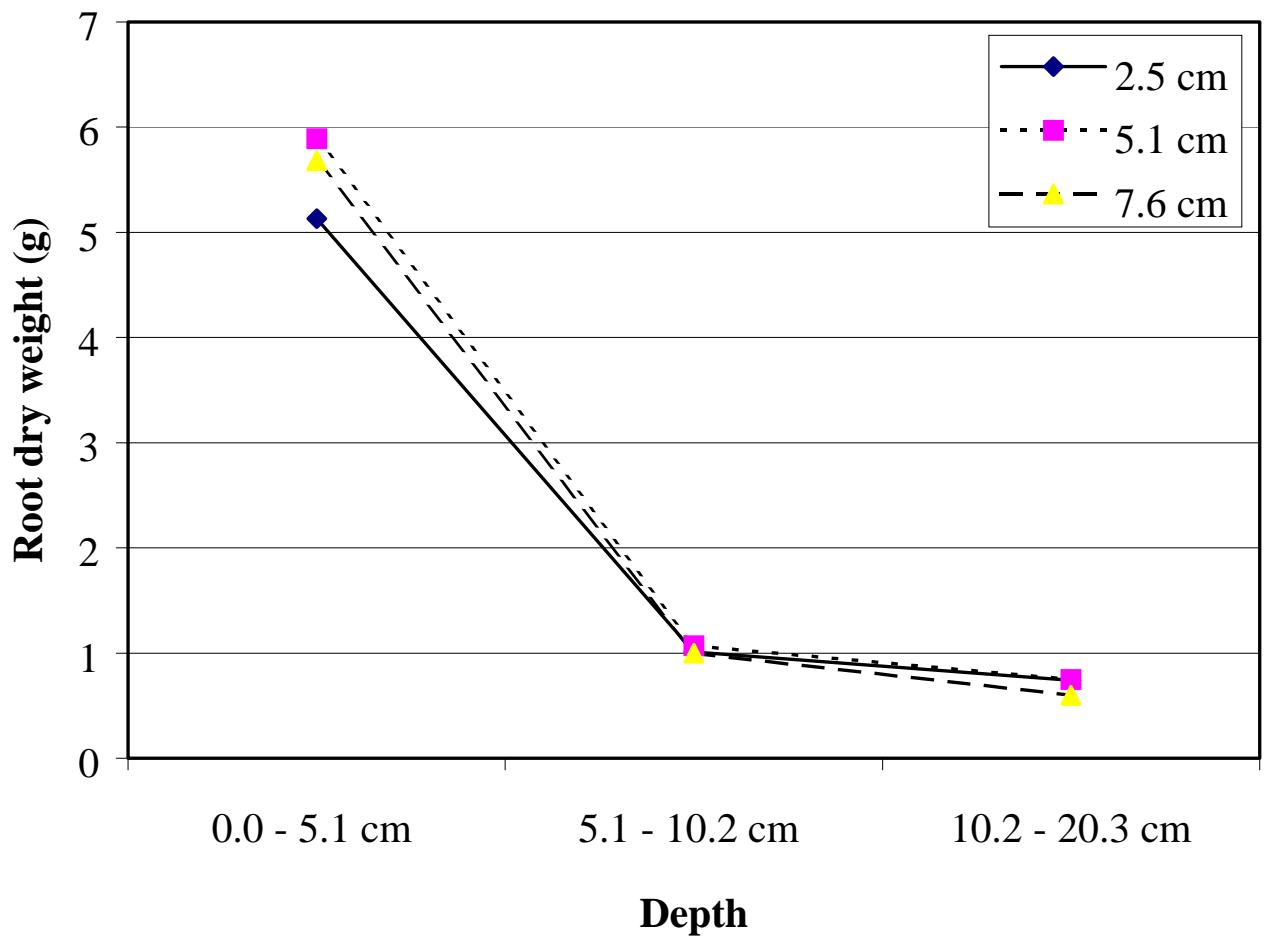

Figure 17: Effect of depth and cutting management on root dry weight. The interaction between depth and cutting management was significant at $\mathrm{P}<0.05$. Depth was significant at $\mathrm{P}<0.0001$, and cutting management was NS.

\section{Root length}

Nitrogen treatments did not significantly affect the root length. Also, no interactions involving $\mathrm{N}$ were found. However, cutting management did significantly ( $\mathrm{P}$ $<0.05$ ) affect root length, but only at the $0.0-5.1 \mathrm{~cm}$ depth (Table 9 and Appendix Table J). At the upper rooting depth, herbage cut to $2.5 \mathrm{~cm}$ had less root length $(2267 \mathrm{~cm})$ than that cut to $7.6 \mathrm{~cm}(2755 \mathrm{~cm})$ (Fig. 18).

Sampling date affected root length at each of the rooting depths (Table 9 and Appendix Table J). A sampling date by depth interaction was also present $(\mathrm{P}<0.0001)$. The pre-treatment samples, April 15, 1999, had significantly $(\mathrm{P}<0.05)$ less root length at the $10.2-20.3 \mathrm{~cm}$ than the post-treatment samples. Root length for the 1999 samples was much lower $(\mathrm{P}<0.01)$ than the 2000 samples, but only at the $0.0-5.1 \mathrm{~cm}$ depth. 
Table 9: Effect of depth, $\mathrm{N}$ treatment, cutting management and sampling date on root length

\begin{tabular}{|c|c|c|c|}
\hline & \multicolumn{3}{|c|}{ Depth } \\
\hline Treatment & $0.0-5.1 \mathrm{~cm}$ & $5.1-10.2$ & $-20.3 \mathrm{~cm}$ \\
\hline \multicolumn{4}{|l|}{$\mathrm{N}$ application } \\
\hline none & 2358 & 1008 & 831 \\
\hline medium & ------- & ------- & ------- \\
\hline high & 2665 & 997 & 894 \\
\hline Significance $^{\dagger}$ & NS & $\mathrm{NS}$ & NS \\
\hline \multicolumn{4}{|l|}{ Cutting Management } \\
\hline $2.5 \mathrm{~cm}$ & 2267 & 961 & 828 \\
\hline $5.1 \mathrm{~cm}$ & ------- & ------- & ------- \\
\hline $7.6 \mathrm{~cm}$ & 2755 & 1045 & 897 \\
\hline Significance & $*$ & NS & NS \\
\hline \multicolumn{4}{|l|}{ Date } \\
\hline April 15, 1999 & 2188 & 854 & 632 \\
\hline May 27, 1999 & 2265 & 1091 & 990 \\
\hline September 22, 1999 & 2386 & 1061 & 839 \\
\hline October 25, 1999 & 1534 & 817 & 651 \\
\hline May 30, 2000 & 4153 & 1448 & 1273 \\
\hline August 28, 2000 & 2412 & 843 & 737 \\
\hline October 13, 2000 & 2640 & 907 & 917 \\
\hline Significance & $* * *$ & $* *$ & $* *$ \\
\hline April 15, 1999 vs. May 27, 1999 to October 13, 2000 & NS & NS & $*$ \\
\hline 1999 vs 2000 & $* *$ & NS & NS \\
\hline September 22, 1999 vs. May 27 and October 25, 1999 & NS & NS & NS \\
\hline May 27, 1999 vs. October 25, 1999 & NS & NS & $*$ \\
\hline August 28, 2000 vs. May 30 and October 13, 2000 & $* *$ & $*$ & $*$ \\
\hline May 30, 2000 vs. October 13, 2000 & $* *$ & $* *$ & $*$ \\
\hline
\end{tabular}

†Significance of $\mathrm{F}$ test. NS, non-significant; *, $\mathrm{P}<0.05 ; * * \mathrm{P}<0.01 ; * * * \mathrm{P}<0.0001$.

Note: Harvest date $\mathrm{x}$ depth interaction was significant for $\mathrm{P}<0.0001$. 


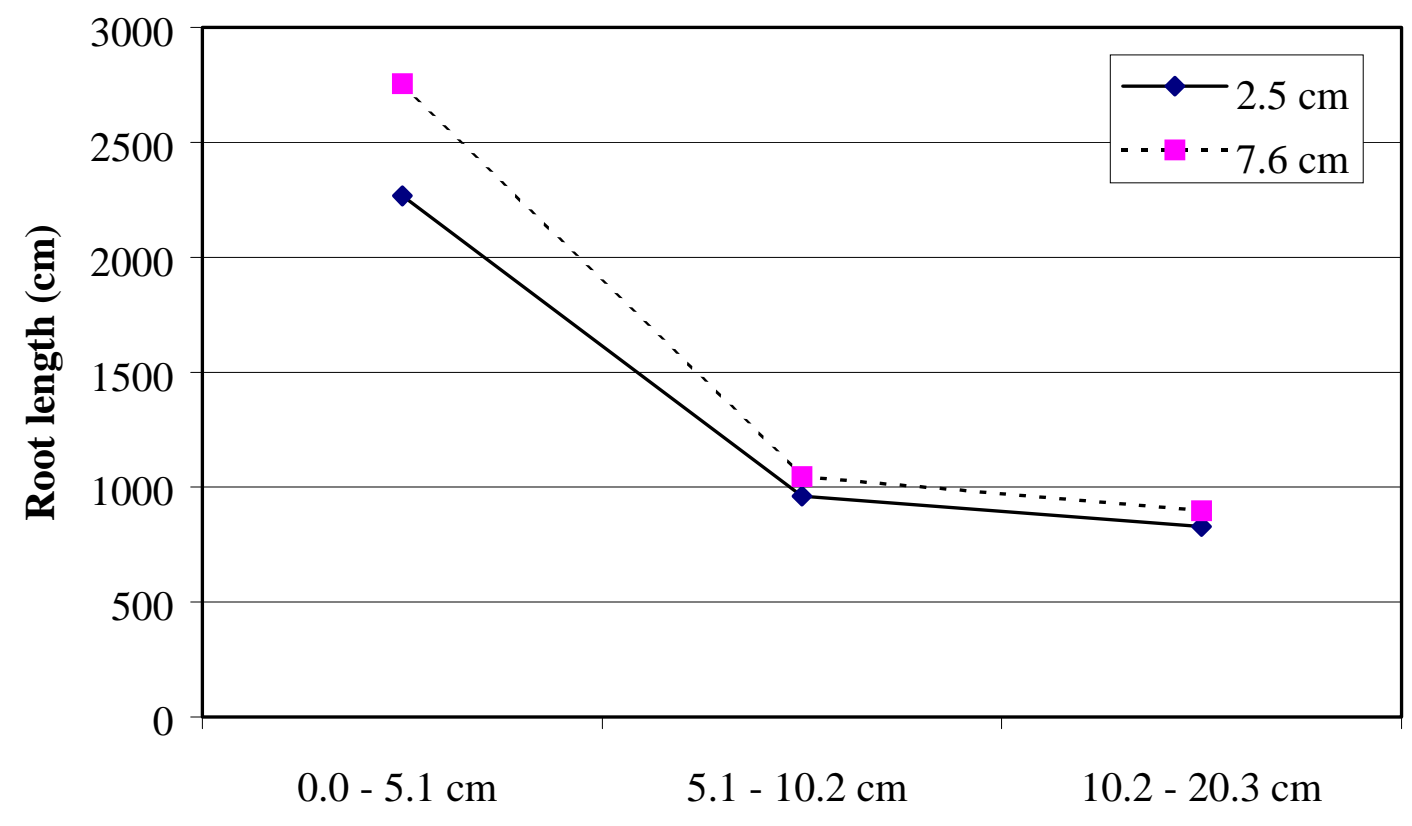

Depth

Figure 18: Effect of depth and cutting management on root length. The interaction between depth and cutting management was significant at $\mathrm{P}<0.05$. Depth was significant at $\mathrm{P}<0.0001$, and cutting management was NS.

No significant differences in root length between the two years were found at the other depths. Root lengths at the $10.2-20.3 \mathrm{~cm}$ depth of the samples taken on May 27, 1999 were greater than those taken on October 25, 1999 at the same depth. Also, at each depth, samples taken on August 28, 2000 had less root length than May 30, 2000 and October 13, 2000. Differences between the latter two dates were also found at each of the three rooting depths. The May 30 samples had significantly greater root length than the October 13 samples.

Depth of sampling had a significant $(\mathrm{P}<0.0001)$ effect on root length. Roots at the $0.0-5.1 \mathrm{~cm}$ depth had a much greater root length than roots at the $5.1-10.2 \mathrm{~cm}$ and $10.2-20.3 \mathrm{~cm}$ depths. However, no significant differences in root length were found between the $5.1-10.2 \mathrm{~cm}$ and $10.2-20.3 \mathrm{~cm}$ depths. 


\section{Soil Nitrate}

The 1999 season

Nitrogen treatment significantly $(\mathrm{P}<0.05)$ affected soil $\mathrm{NO}_{3}{ }^{-}$concentrations.

However, these differences were only significant between the no $\mathrm{N}$ level compared to the medium and high $\mathrm{N}$ levels (Table 10 and Appendix Table K). Average soil $\mathrm{NO}_{3}{ }^{-}$ concentrations for the low, medium and high $\mathrm{N}$ treatments were: $0.43,0.83$ and $1.28 \mu \mathrm{g}$ $\mathrm{N} \mathrm{cm}^{-2}$ day $^{-1}$, respectively.

Date of $\mathrm{N}$ application also affected soil $\mathrm{NO}_{3}{ }^{-}$levels. The soil treated in June had significantly $(\mathrm{P}<0.01)$ lower $\mathrm{NO}_{3}{ }^{-}$levels than the September 1999 application (Table 10 and Appendix Table $\mathrm{K}$ ). The average soil $\mathrm{NO}_{3}{ }^{-}$concentration after the June application was $0.59 \mu \mathrm{g} \mathrm{N} \mathrm{cm}^{-2} \mathrm{day}^{-1}$. However, in September, the average concentration was 1.10 $\mu \mathrm{g} \mathrm{Nm}^{-2}$ day $^{-1}$.

In 1999, anion transfer membranes in each block were grouped according to $\mathrm{N}$ treatments for analysis, and cutting treatment effects could not be determined.

The 2000 season

Nitrogen application was also found to significantly $(\mathrm{P}<0.05)$ affect soil $\mathrm{NO}_{3}^{-}$ concentrations in the 2000 season. Soil with no $\mathrm{N}$ added had a significantly $(\mathrm{P}<0.05)$ lower soil $\mathrm{NO}_{3}{ }^{-}$concentration $\left(1.00 \mu \mathrm{g} \mathrm{N} \mathrm{cm}{ }^{-2}\right.$ day $\left.^{-1}\right)$ compared to soil to which medium $\left(1.71 \mu \mathrm{g} \mathrm{N} \mathrm{cm}^{-2}\right.$ day $\left.^{-1}\right)$ and high levels of $\mathrm{N}$ were applied $\left(1.87 \mu \mathrm{g} \mathrm{N} \mathrm{cm}^{-2}\right.$ day $\left.^{-1}\right)$ (Table 10 and Appendix Table K). However, there was no difference between the medium and high $\mathrm{N}$ treatments.

The effects of cutting treatment were determined in the 2000 season. The $2.5 \mathrm{~cm}$ cutting treatment resulted in significantly $(\mathrm{P}<0.01)$ greater soil $\mathrm{NO}_{3}{ }^{-}$concentrations 
Table 10: Effect of $\mathrm{N}$ treatment, cutting management and $\mathrm{N}$ application date on soil nitrate concentration in 1999 and 2000.

\begin{tabular}{ccc} 
& \multicolumn{2}{c}{$\begin{array}{c}\text { Average } \mathbf{N O}_{3}{ }^{-} \\
\text {Concentration }\end{array}$} \\
\cline { 2 - 3 } Treatment & $\mathbf{1 9 9 9}$ & $\mathbf{2 0 0 0}$ \\
\hline N application & $--\mu \mathrm{N} \mathrm{cm}^{-2}$ & $\mathrm{~d}^{-1}---$ \\
none & 0.43 & 1.00 \\
high & 0.84 & 1.71 \\
Significance & \\
none vs. medium and high & $*$ & 1.88 \\
medium vs. high & $*$ & $*$ \\
& $\mathrm{NS}$ & $\mathrm{NS}$
\end{tabular}

\section{Cutting management}

$\begin{array}{lll}2.5 \mathrm{~cm} & ------ & 2.09 \\ 5.1 \mathrm{~cm} & ------ & 1.32 \\ 7.6 \mathrm{~cm} & ------ & 1.18\end{array}$

Significance

$2.5 \mathrm{~cm}$ vs. 5.1 and $7.6 \mathrm{~cm} \quad-----\quad * *$

$5.1 \mathrm{~cm}$ vs. $7.6 \mathrm{~cm} \quad$----- $\quad$ NS

\section{$N$ application date}

June 3, 1999

$0.59 \quad------$

September 10, 1999

1.10

June 2, 2000

$-\cdot-\cdot--$

2.13

August 30, 2000

$------$

0.93

${ }^{\dagger}$ Significance of $\mathrm{F}$ test. NS, non-significant; *, $\mathrm{P}<0.05$;

$* * \mathrm{P}<0.01$; *** $\mathrm{P}<0.0001 ; \mathrm{NS}=$ not significant.

Note: $\mathrm{N} x$ cutting management $\mathrm{x}$ date interaction in 2000 was significant at $\mathrm{P}<0.05$. 


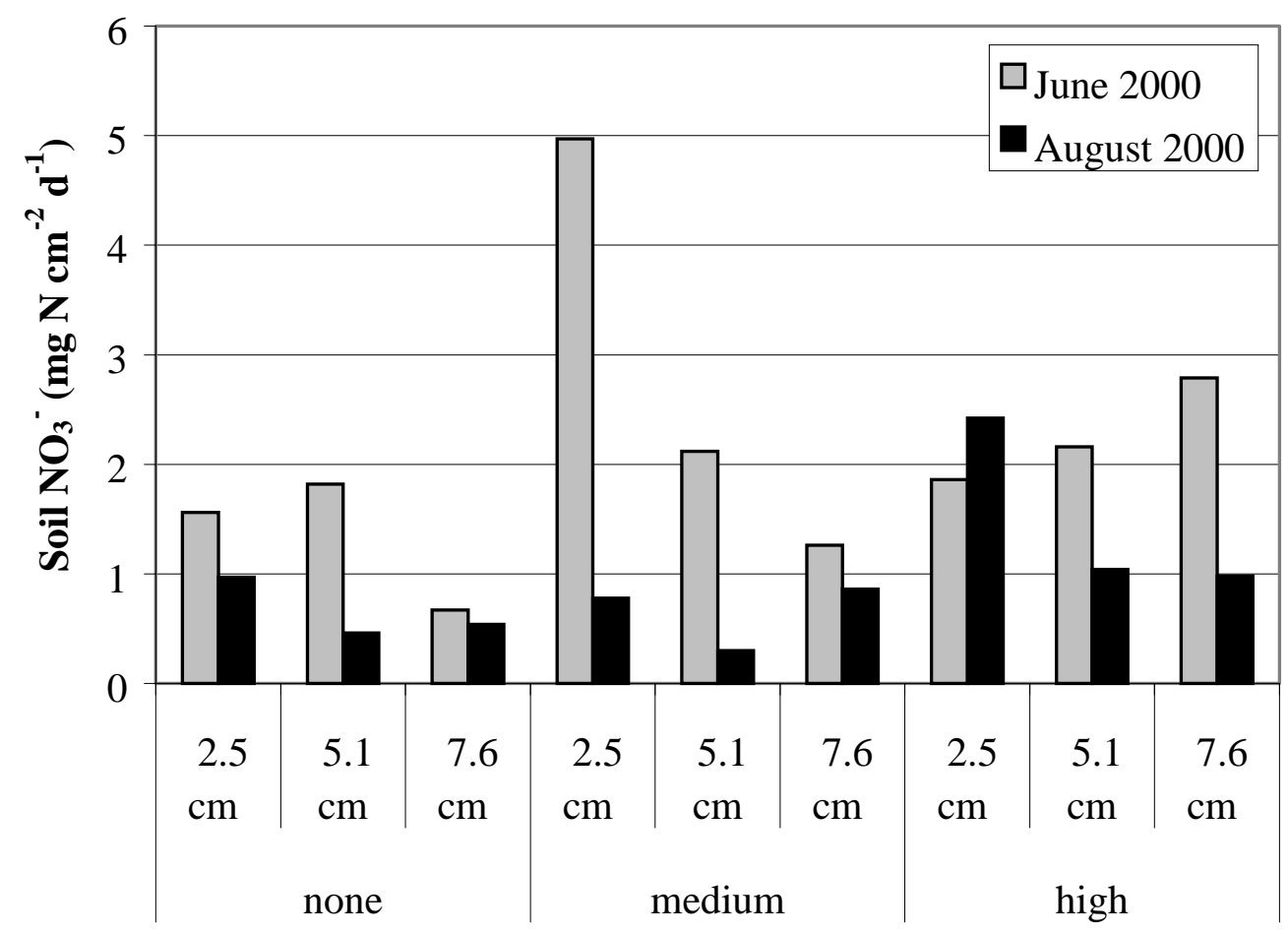

Treatments ( $\mathbf{N}$ and cutting management)

Figure 19: Effect of $\mathrm{N}$ treatment, cutting management and sampling date on soil $\mathrm{NO}_{3}{ }^{-}$ concentration in 2000. The interaction between $\mathrm{N}$ treatment, cutting management and sampling date was significant at $\mathrm{P}<0.05$. Nitrogen and cutting management were significant at $\mathrm{P}<0.05$. Sampling date was significant at $\mathrm{P}<0.0001$.

than did cutting treatments 5.1 and $7.6 \mathrm{~cm}$ (Table 10 and Appendix Table K). The average soil $\mathrm{NO}_{3}{ }^{-}$concentrations of the $2.5,5.1$ and $7.6 \mathrm{~cm}$ cutting managements were: 2.09, 1.32 and $1.18 \mu \mathrm{g} \mathrm{N} \mathrm{cm}^{-2} \mathrm{day}^{-1}$. No significant differences were found between the 5.1 and $7.6 \mathrm{~cm}$ cutting managements.

Date significantly $(\mathrm{P}<0.0001)$ affected soil $\mathrm{NO}_{3}{ }^{-}$concentrations in 2000.

However, unlike the 1999 season, the June 2000 date resulted in significantly higher soil $\mathrm{NO}_{3}{ }^{-}$concentrations than August 2000. The average soil $\mathrm{NO}_{3}{ }^{-}$concentration for June was $2.13 \mu \mathrm{g} \mathrm{N} \mathrm{cm}^{-2}$ day $^{-1}$; the average for August was $0.93 \mu \mathrm{g} \mathrm{N} \mathrm{cm}^{-2}$ day $^{-1}$ (Table 10 and Appendix Table K). 
An interaction $(\mathrm{P}<0.05)$ between $\mathrm{N}$, cutting management and date was present (Fig. 19). All soil $\mathrm{NO}_{3}{ }^{-}$concentrations at each level of $\mathrm{N}$ and for all three cutting managements, except the high $\mathrm{N}$ and $2.5 \mathrm{~cm}$ cut, were highest in June 2000.

\section{Soil Samples}

The $\mathrm{pH}$ of the soil was significantly $(\mathrm{P}<0.01)$ affected by year, being slightly higher in 1999 (6.37) than 2000 (6.29). Year also significantly $(\mathrm{P}<0.0001)$ affected available soil phosphorous $(\mathrm{P})$, calcium $(\mathrm{Ca})$ and magnesium $(\mathrm{Mg})$. Available soil $\mathrm{P}$ and Mg were greater in 1999. However, available Ca was greater in 2000 (Table 11 and Appendix Table L). Nitrogen and cutting treatments had no significant effects on soil $\mathrm{pH}, \mathrm{P}, \mathrm{Ca}$ and $\mathrm{Mg}$. There were no differences between the sampling depths.

$\mathrm{N}$ application level, cutting management or sample year, did not significantly affect the availability of potassium $(\mathrm{K})$ in the soil. However, an interaction between $\mathrm{N}$ and year was present $(\mathrm{P}<0.05)$. Soil $\mathrm{K}$ was greater in 1999 at the no $\mathrm{N}$ and the medium $\mathrm{N}$ treatments and in 2000 at the high $\mathrm{N}$ treatment. An interaction was also present between cutting management and year $(\mathrm{P}<0.01)$. There was more available K in 1999 when cutting management was $2.5 \mathrm{~cm}$. In 2000, available $\mathrm{K}$ in the soil was greater under the 5.1 and $7.6 \mathrm{~cm}$ cutting managements. No differences in available $\mathrm{K}$ were found between soil sampling depths. 
Table 11: Effect of $\mathrm{N}$ treatment, cutting management and year on $\mathrm{pH}$ and available $\mathrm{P}, \mathrm{K}$, $\mathrm{Ca}$ and $\mathrm{Mg}$ of soil

\begin{tabular}{cccccc}
\hline & \multicolumn{5}{c}{ Available } \\
Treatment & $\mathbf{p H}$ & $\mathbf{P}$ & $\mathbf{K}$ & $\mathbf{C a}$ & $\mathbf{M g}$ \\
\hline & & & - & & \\
N application & & & & & \\
none & 6.4 & 60 & 259 & 4211 & 189 \\
medium & 6.4 & 61 & 246 & 3989 & 186 \\
high & 6.3 & 56 & 247 & 3871 & 193 \\
Significance $^{\dagger}$ & NS & NS & NS & NS & NS
\end{tabular}

\section{Cutting management}

$\begin{array}{rccccc}2.5 \mathrm{~cm} & 6.3 & 57 & 249 & 4116 & 186 \\ 5.1 \mathrm{~cm} & 6.4 & 60 & 248 & 4005 & 190 \\ 7.6 \mathrm{~cm} & 6.3 & 60 & 254 & 3946 & 191 \\ \text { Significance } & \text { NS } & \text { NS } & \text { NS } & \text { NS } & \text { NS }\end{array}$

Year

\begin{tabular}{cccccc}
1999 & 6.4 & 62 & 254 & 3568 & 203 \\
2000 & 6.3 & 56 & 247 & 4453 & 176 \\
Significance & $* *$ & $* * *$ & $\mathrm{NS}$ & $* * *$ & $* * *$ \\
\hline${ }^{+}$Significance of F test. NS, non-significant, $*, \mathrm{P}<0.05 ; * * \mathrm{P}<0.01 ; * * * \mathrm{P}<0.0001$. \\
Note: For K: \\
-N x year interaction was significant at $\mathrm{P}<0.05$. \\
-Cutting management x year interaction was significant at $\mathrm{P}<0.01$.
\end{tabular}

\section{Climate}

Average temperatures in 1999 and 2000 were similar from April to October (Fig. 20). Compared to 1999, the average temperature was about $5 \mathrm{C}$ higher in March 2000 and about $4 \mathrm{C}$ less in July 2000. Overall, the 1999 season had much less rainfall than the 2000 season (Fig. 21). From May to August approximately $20 \mathrm{~cm}$ more rainfall was recorded in 2000 compared to 1999 . However, approximately $5 \mathrm{~cm}$ more rainfall was recorded for September 1999 than September 2000. Rainfall was not recorded for October 2000. 


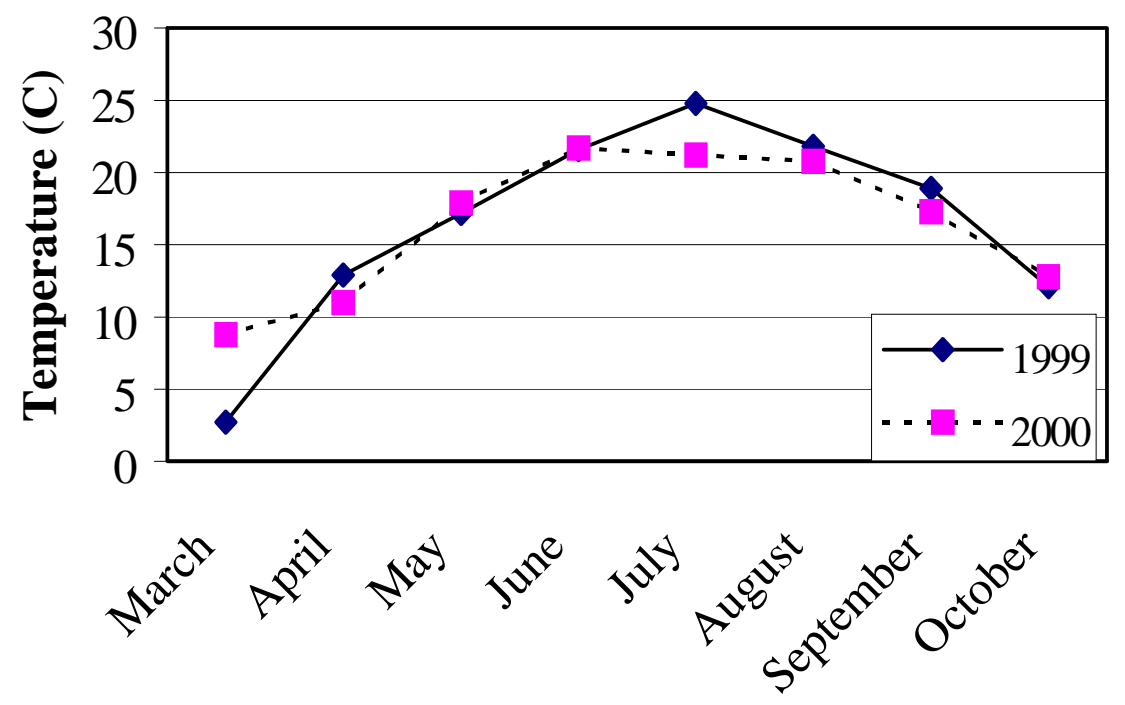

Month

Figure 20: Average monthly temperature from March to October 1999 and 2000, as recorded at Morgantown Municipal Airport.

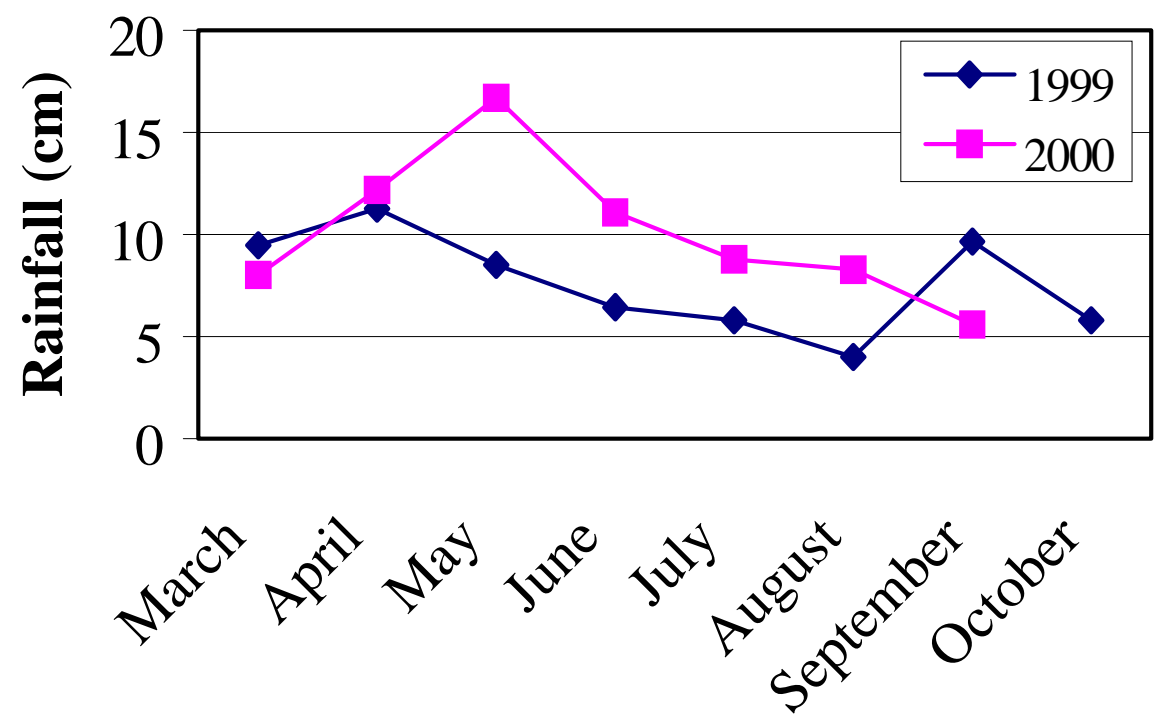

Month

Figure 21: Total monthly rainfall from March to October 1999 and 2000, as recorded at Morgantown Municipal Airport. 


\section{DISCUSSION}

\section{Pasture Production and Quality}

In 1999, rainfall was much lower than in 2000. The highly significant effect of year on plant production and quality is a result of differences in rainfall between 1999 and 2000. The same is true for significant interactions found involving year, $\mathrm{N}$ treatment and/or cutting management. Herbage accumulation, $\mathrm{CP}$ concentration, $\mathrm{CP}$ yield, and ADF concentrations of herbage were all much higher in 2000 compared to 1999. MacKlon, et al., (1996) found that herbage accumulation in pastures decreased 25 to $50 \%$ in dry years compared to years with normal rainfall, and changes in soil water affected the $\mathrm{N}$ content of the herbage. However, herbage NDF concentration was higher in 1999. This higher ADF concentration may be attributed to the delay of plant maturity caused by the drought stress.

Harvest date (in 1999 and 2000) and harvest period (2000 only) significantly affected CP concentration, CP yield and NDF and ADF concentrations. These effects were probably caused by rainfall, stand maturity, timing of $\mathrm{N}$ applications, and/or the frequency of harvest.

\section{Effects of nitrogen fertilizer}

Herbage accumulation, $\mathrm{CP}$ yield, and NDF and ADF concentrations were not

affected by the addition of $\mathrm{N}$ fertilizer. Although there was no significant main effect of $\mathrm{N}$ on $\mathrm{CP}$ concentration, orthogonal comparisons did indicate that $\mathrm{CP}$ concentration was lower in herbage receiving no $\mathrm{N}$ compared to herbage receiving medium and high $\mathrm{N}$ levels. 
Response of a grass-legume stand to $\mathrm{N}$ fertilization depends on plant species, botanical composition, soil moisture and availability of other necessary nutrients (Baylor, 1974). In terms of herbage accumulation, the yield responses from $\mathrm{N}$ fertilization have been shown to be small. In alfalfa-grass mixtures applications of up to $112 \mathrm{~kg} \mathrm{~N} \mathrm{ha}^{-1}$ have resulted in no yield increase to only slight yield increases (Parsons, 1958). Carter and Scholl (1962) found similar results and attributed the slight yield increase to an increase in the percentage of grass in the stand. Generally, a higher grass percentage in the stand will result in a greater yield response to N (Baylor, 1974).

The timing of $\mathrm{N}$ applications can be very important. Wedin (1974) states that cool-season grasses fertilized before the cool season starts have a very high $\mathrm{N}$ use efficiency. In this experiment $\mathrm{N}$ fertilizer was applied in early June, when Kentucky bluegrass has already reached its growth peak, and in late August, before the usual fall increase. Perhaps the lack of response to $\mathrm{N}$ was a result of applying $\mathrm{N}$ too late in the spring, after the peak of growth. Since rainfall was low following both $\mathrm{N}$ fertilization times in 1999 and after the August fertilization in 2000, the plants may have taken up less $\mathrm{N}$. Therefore, they would not have responded well, if at all, to the $\mathrm{N}$ application. The low rainfall in 1999 and in late summer of 2000 influenced the production and quality of herbage.

The effect of $\mathrm{N}$ fertilization on $\mathrm{CP}$ has been shown to parallel the effect of $\mathrm{N}$ fertilization on yield (Cosper and Thomas, 1961; Reid and Castle, 1965). Crude protein concentration of forage is dependent not only on $\mathrm{N}$ fertilization, but plant species, existing soil fertility and cutting management (Baylor, 1974). In mixed swards, $\mathrm{N}$ fertilization will often favor grasses and subsequently decrease the percent of legumes 
present. This decrease of legume may also decrease protein concentration of the sward (Baylor, 1974).

The CP concentration increased when plants were fertilized with $\mathrm{N}$, but only in 1999. The below normal rainfall in 1999 caused $\mathrm{N}$ to be more concentrated in the herbage. Crude protein is directly related to the $\mathrm{N}$ concentration in plants. Nuttall (1980) found that as $\mathrm{N}$ fertilization rates increased so did the concentration of $\mathrm{N}$ in bromegrass. Therefore, it is reasonable to assume that in this study, the addition of $\mathrm{N}$ fertilizer increased the $\mathrm{N}$ concentration of the herbage, thus increasing $\mathrm{CP}$ concentration.

The $\mathrm{N}$ treatment by harvest period interaction showed that $\mathrm{CP}$ concentration of herbage for all $\mathrm{N}$ treatment levels, except the medium $\mathrm{N}$ level, increased as harvest period increased. The cause of this interaction is not clear. The $\mathrm{N}$ treatment by harvest date interaction showed that herbage treated with the medium $\mathrm{N}$ level had the lowest $\mathrm{CP}$ concentrations at every harvest date in 2000, except on June 29, when it had the highest $\mathrm{CP}$ concentrations. This was probably a result of the first $\mathrm{N}$ fertilization approximately three weeks prior to the harvest.

Crude protein yields were not different between the plants fertilized with $\mathrm{N}$ and those that were not fertilized with $\mathrm{N}$. The result is not like that found for the CP concentration in forage. This is probably because herbage yield was not affected by $\mathrm{N}$ applications.

Fiber (NDF and ADF) concentration of herbage is usually not strongly affected by $\mathrm{N}$ fertilization, as shown by the results of this experiment. The results of several other studies agree. Nitrogen fertilization increased yield and CP, but not plant digestibility or percent fiber (Williams, 1962; Washko, 1963; Hart and Burton, 1965). 


\section{Effects of cutting management}

Cutting management greatly affected herbage accumulation, $\mathrm{CP}$ concentration and yield, and NDF and ADF concentrations. The $2.5 \mathrm{~cm}$ cutting management yielded more herbage than the 5.1 and $7.6 \mathrm{~cm}$ cutting managements. Frequency of harvest did not seem to be the reason for this difference in herbage accumulation. In 1999, the $2.5 \mathrm{~cm}$ treatment was harvested at about the same frequency as the 5.1 and $7.6 \mathrm{~cm}$ treatments. In 2000, it was harvested slightly fewer times than the 5.1 and $7.6 \mathrm{~cm}$ treatments (Table 2). Therefore, the cutting intensity was the reason for differences in herbage accumulation. However, Bryan et al. (2000) found that when defoliation occurred with high frequency and intensity growth rate was reduced. The authors concluded that herbage accumulation was greatest with frequent defoliation of approximately $50 \%$ (low intensity) of the herbage. However, the study did find that amount of rainfall greatly affected herbage production. In a dry year, such as 1999 , grazing intensity and frequency did not have much affect on herbage growth.

Crude protein concentration, which improves animal performance, was highest in herbage harvested to $7.6 \mathrm{~cm}$ and lowest in herbage harvested to $2.5 \mathrm{~cm}$. Mortimer and Ahlgren (1936) found similar results. They found that increased cutting intensity decreased the $\mathrm{CP}$ concentration of Kentucky bluegrass. Nitrogen concentration is usually greatest in leaf blades, lower in stems and even lower in roots (Vance and Heichel, 1981). Also, the allocation of $\mathrm{N}$ is dependent on light and photosynthesis. Leaves on the upper part of the plant receive more light and have higher $\mathrm{N}$ concentrations than leaves lower in the canopy (Field, 1983; Hirose and Werger, 1987; Pons et al., 1989). As the cutting height gets lower, the amount of herbage harvested lower on the plant increases. Since 
the herbage harvested at the $7.6 \mathrm{~cm}$ cutting management contained mostly the upper leaves, the $\mathrm{N}$ and $\mathrm{CP}$ concentrations were higher than at the 5.1 and $2.5 \mathrm{~cm}$ cutting managements.

The reasons for the interactions found between cutting management and harvest period and $\mathrm{N}$ treatment, cutting management and harvest period in 2000 are not clear. Both interactions indicate that for the $2.5 \mathrm{~cm}$ cutting management herbage $\mathrm{CP}$ concentration was lowest in harvest period three. This could be the result of the lower rainfall in that period. Also, there was a six-week span between the $2.5 \mathrm{~cm}$ harvests of herbage in periods 2 and 3 . This long regrowth period may have lowered the $\mathrm{N}$ and $\mathrm{CP}$ concentration in the herbage.

Unlike $\mathrm{CP}$ concentration of herbage, $\mathrm{CP}$ yield was greatest for the $2.5 \mathrm{~cm}$ cutting management. Although CP concentration was lower, the amount of herbage harvested at this cutting management compensated for the low $\mathrm{CP}$ concentration.

Herbage quality is never constant; therefore, NDF and ADF concentrations are highly dependent on the maturity of the plant and harvest date. As a plant matures the cell wall increases in lignin and fiber. Leaves contain less fiber than stems, and younger leaves have less fiber than older leaves. The results of this experiment show that both NDF and ADF increased with increased harvest intensity. Because all treatments were allowed to grow to $12.7 \mathrm{~cm}$ before they were harvested, maturity and age of the leaves at harvest was not a factor. However, the type of plant material harvested varied by cutting management. The plant material harvested under the $7.6 \mathrm{~cm}$ cutting management was primarily the younger leaves of the sward. Since it has been established that younger leaves have lower fiber concentrations, the NDF and ADF concentrations found in this 
herbage would also be lower. However, as cutting management intensity increased, the age, NDF and ADF concentrations of the harvested herbage also increased.

Interactions between cutting management and harvest period were found for NDF and ADF. In harvest period 1, there was little difference between the fiber content of the herbage cut at different heights. Compared to the 5.1 and $7.6 \mathrm{~cm}$ cutting managements, the herbage harvested at the $2.5 \mathrm{~cm}$ cutting management had slightly to much higher concentrations of both NDF and ADF in harvest period 3. In 2000, the sward cut to the $2.5 \mathrm{~cm}$ was only harvested once in period 2 and once in period 3. Before these harvests, approximately 4 to 6 weeks elapsed. During this time the herbage continued to mature. Therefore, when the herbage treated with the $2.5 \mathrm{~cm}$ cutting management was finally harvested, the plant material contained much more fiber.

For NDF, an interaction between $\mathrm{N}$ treatment, cutting management and harvest period was found in 2000. The NDF concentration was greatest in period 2 for herbage at all treatments, except the no $\mathrm{N} / 2.5 \mathrm{~cm}$ and medium N/2.5 cm treatments. The latter two treatment combinations resulted in the highest herbage NDF in harvest period 3. Because the herbage cut to $2.5 \mathrm{~cm}$ was not harvested in period 3 after $\mathrm{N}$ fertilizer was applied, it is not clear why this interaction occurred. The reason is probably related to the cutting management by harvest period interaction mentioned in the previous paragraph.

\section{Pasture Root Growth}

Root volume, dry weight and length were about 4 times greater in the upper sampling depth $(0.0-5.1 \mathrm{~cm})$ compared to the lower two depths $(5.1-10.2$ and $10.2-$ $20.3 \mathrm{~cm}$ ). These results confirm the findings in the literature cited that compared to 
similar grasses, Kentucky bluegrass has a rather shallow root system. Generally it has a larger root mass and greater root development in the top $7.6 \mathrm{~cm}$ (3 in) of soil, and root mass and development have been shown to decrease very quickly at lower rooting depths (Gist and Smith, 1948). Also, because white clover is a shallow-rooted plant, the majority, if not all, of its roots would have been found in the top sampling depth. Therefore, compared to other plants, Kentucky bluegrass and white clover are more able to compete for water and nutrients in the upper $5.1 \mathrm{~cm}$ of the soil than at lower depths.

At the $0.0-5.1 \mathrm{~cm}$ depth the root volume, dry weight and length of Kentucky bluegrass were greater in 2000 compared to 1999 . This may be explained by below normal rainfall in 1999 compared to above normal rainfall in 2000. Available water in the upper soil layer was quickly depleted by the large root volume and by evaporation. Regular rainfall would have been needed to maintain root growth.

Root mass varied according to sampling date; however, differences between sampling dates were more pronounced in 2000 than in 1999. At most depths in 1999 and at all depths in 2000, the May root samples had the greatest root volume, dry weight and length. Autumn and spring usually favor root growth and production of Kentucky bluegrass because soil temperatures are lower (Brown, 1943). However, root growth is usually greatest in the spring (Sprague, 1933; Stuckey, 1941). Hanson and Juska (1961) found that the growth of Kentucky bluegrass roots increases in February and March, and this stimulated growth continues through May. Because the greatest root volumes, dry weight and lengths were usually found in the May root samples, the results of the experiment agree with the results of Hanson and Juska. 


\section{Effects of nitrogen fertilizer}

Medium and high $\mathrm{N}$ applications increased root volume and dry weight, however, only in the $0.0-5.1 \mathrm{~cm}$ rooting depth. These results can be explained by the results of other experiments. Uptake of $\mathrm{N}$ is dependent on the concentration of $\mathrm{N}$ and the rate of plant growth (Drew, 1975). Generally, plants receiving no $\mathrm{N}$ have significantly lower root weights than plants fertilized with $\mathrm{N}$. However, there is usually little difference in root weight between plants receiving low and high $\mathrm{N}$ applications as long as the levels of other necessary nutrients are adequate (Benedict and Brown, 1944; Holt and Fisher, 1960; Lorenz and Rogler, 1966). Also, $\mathrm{N}$ fertilization in September can often increase the amount of roots produced during the winter months (Hanson and Juska, 1961).

The root volume and dry weight in the top $5.1 \mathrm{~cm}$ of soil was much greater than the root volumes and dry weights at the other two depths. This finding may be explained by the rooting characteristics of Kentucky bluegrass and white clover that were mentioned previously. However, it may also be explained by the availability of nutrients. Root development is often altered by the availability of nutrients in the soil profile; more roots are usually found in soil volumes high in necessary nutrients (Drew, 1975). Since the $\mathrm{N}$ fertilizer was applied to the soil surface the $\mathrm{N}$ concentration was probably highest in the top $5.1 \mathrm{~cm}$ of the soil. Therefore, higher root volumes and dry weights were found in the top layer because roots usually proliferate in areas of higher $\mathrm{N}$ concentration (Vogt et al., 1993). This may also explain why no differences in root length between $\mathrm{N}$ treatments were found in the $5.1-10.2 \mathrm{~cm}$ and $10.2-20.3 \mathrm{~cm}$ depths. However, no differences in root length between the no $\mathrm{N}$ and high $\mathrm{N}$ treatments were found in the top rooting depth either. 


\section{Effects of cutting management}

Cutting management had a greater effect on root growth at the $0.0-5.1 \mathrm{~cm}$ depth than at any other depth. The experimental results showed that, at the $0.0-5.1 \mathrm{~cm}$ depth, root volume, dry weight and length were lower for plants cut to $2.5 \mathrm{~cm}$ compared to those cut to 5.1 and $7.6 \mathrm{~cm}$. This effect of defoliation height is similar to that found by Sprague (1933) and Coupland et al. (1960). For a stand of Kentucky bluegrass maintained at a height of $2.2 \mathrm{~cm}$ ( $0.9 \mathrm{in})$ compared to an uncut stand, Sprague only found differences in the root dry weights in the $0.0-2.5 \mathrm{~cm}$ depth. An explanation for the effect of cutting management at the top sampling depth may be that severe defoliation reduces the size of the roots and causes less branching to occur in the upper soil layer (Schuster, 1964).

Defoliation generally reduces or stops root growth temporarily, and it has been found to reduce root mass (Thornton and Millard, 1996). However, regrowth of roots is generally rapid. Similarly, soon after $50 \%$ or more herbage is removed from $\mathrm{C}_{3}$ grasses, root growth often ceases (Richards, 1993) and some of the fine roots may senesce. In this experiment because more than $50 \%$ of the shoots were removed when the herbage was defoliated to $2.5 \mathrm{~cm}$, root growth probably stopped almost immediately. Therefore, the root volume, dry weight and length would subsequently decrease. However, more than $50 \%$ of the shoots were also removed at the $5.1 \mathrm{~cm}$ cutting management, and root volume, dry weight and length were not affected as much. Because the $5.1 \mathrm{~cm}$ cutting management was not as severe as the $2.5 \mathrm{~cm}$ cutting management, the plants may have been able to recover sooner. Therefore, the amount of time during which root growth ceased may have been shorter at the $5.1 \mathrm{~cm}$ cutting height. Also, fewer fine roots may have senesced. 


\section{Soil Nitrate}

\section{Effects of nitrogen fertilizer}

In both 1999 and 2000, soil treated with no $\mathrm{N}$ had lower soil $\mathrm{NO}_{3}{ }^{-}$concentrations than soil treated with the medium and high $\mathrm{N}$ levels. It is reasonable to assume that soil $\mathrm{NO}_{3}{ }^{-}$levels will be lower in soils to which no $\mathrm{N}$ has been added. In related experiments, a strong relationship was found between $\mathrm{N}$ application level and $\mathrm{NO}_{3}{ }^{-}$desorbed to the ion membrane strips (Pare et al., 1995; Ziadi and Simard, 1996; Collins and Allinson, 1999). The results of this experiment do not totally agree since no differences in soil $\mathrm{NO}_{3}{ }^{-}$were found between the medium and high $\mathrm{N}$ applications; however, the differences between the medium and high $\mathrm{N}$ treatments were close to significant. Because $\mathrm{N}$ flow and uptake are dependent on water flow and uptake, the absence of a difference between the medium and high $\mathrm{N}$ fertilization levels could be attributed to the lower rainfall in 1999 and part of 2000. When water supply is low soil $\mathrm{NO}_{3}{ }^{-}$is "incompletely exploited" (Havill et al., 1977). The differences found between years and $\mathrm{N}$ application dates can be attributed to the amount of rainfall received. The concentration of $\mathrm{NO}_{3}{ }^{-}$desorbed by the anion transfer membranes appeared to be directly proportional to rainfall. For example, the amount of $\mathrm{NO}_{3}{ }^{-}$desorbed to ion transfer membranes was about 2 to 4 times greater for the June $2000 \mathrm{~N}$ application compared to any other time. The amount of rainfall received in June 2000 was approximately $11 \mathrm{~cm}, 5$ to $7 \mathrm{~cm}$ greater than the amount of rainfall received following other $\mathrm{N}$ applications (Fig. 21). Also, rainfall in late summer and fall of 1999 was approximately $4 \mathrm{~cm}$ greater than late spring and early to mid-summer; soil $\mathrm{NO}_{3}{ }^{-}$concentrations were found to be 2 times greater in September 1999 compared to 
June 1999. The results also indicate that soil $\mathrm{NO}_{3}{ }^{-}$was better exploited by plant roots when rainfall was higher.

The root growth patterns of Kentucky bluegrass and white clover could have also contributed to soil $\mathrm{NO}_{3}{ }^{-}$concentrations. The extent of a root system is a strong indicator of the ability of plants to compete for and absorb $\mathrm{NO}_{3}{ }^{-}$from the soil (Andrews and Newman, 1970). The ion transfer membranes were inserted to a depth of approximately $15 \mathrm{~cm}$, but, as previously described, most of the root mass was present in the upper 5.1 $\mathrm{cm}$ of the soil. Also, in drier weather temperatures may be higher and more $\mathrm{N}$ may volatilize. It is possible that, because $\mathrm{N}$ was applied to the soil surface, and the amount of rainfall was generally low, most of the $\mathrm{NO}_{3}{ }^{-}$was taken up by the roots in the upper 5.1 $\mathrm{cm}$ of soil. Therefore, little $\mathrm{NO}_{3}{ }^{-}$was available to leach to the depth of the ion transfer membrane strip.

\section{Effects of cutting management}

In 2000, the soil in plots of pasture plants cut to $2.5 \mathrm{~cm}$ had higher concentrations of $\mathrm{NO}_{3}{ }^{-}$. This too can be attributed to the size of the root system. Because the more severe defoliation decreased root volume, dry weight and length, there were fewer roots to take up large amounts of $\mathrm{NO}_{3}{ }^{-}$. Therefore, more $\mathrm{NO}_{3}{ }^{-}$was able to leach to the depth of the ion transfer membrane than under pasture cut higher.

There was an interaction found between $\mathrm{N}$ level, cutting management and date in 2000. Soil $\mathrm{NO}_{3}{ }^{-}$concentrations for each $\mathrm{N}$ level and cutting management were highest in June 2000, except the high $\mathrm{N}$ and $2.5 \mathrm{~cm}$ cut. In June rainfall was higher; therefore, the $\mathrm{NO}_{3}{ }^{-}$moved through the soil quickly. Under the high $\mathrm{N}$ and $2.5 \mathrm{~cm}$ cutting management the smaller root system would have taken up less $\mathrm{NO}_{3}{ }^{-}$from the soil. This coupled with 
the higher $\mathrm{N}$ rate would have made more $\mathrm{NO}_{3}{ }^{-}$available to leach through the soil. It is possible that the higher rainfall could have caused much of the $\mathrm{NO}_{3}{ }^{-}$to leach through the soil too quickly for it to be taken up by the ion transfer membrane. However, in August and September 2000, the low rainfall would have reduced the mobility of $\mathrm{NO}_{3}{ }_{3}$, allowing it to be available to desorb to the ion transfer membrane. 


\section{CONCLUSIONS}

The results of this experiment indicate that herbage accumulation, $\mathrm{CP}$ concentration and yield, and NDF and ADF concentration of herbage were strongly influenced by cutting management. Although the $2.5 \mathrm{~cm}$ cutting management resulted in higher herbage production and $\mathrm{CP}$ yields, the $7.6 \mathrm{~cm}$ cutting management produced herbage of higher quality. However, the amount of herbage harvested at the $2.5 \mathrm{~cm}$ cutting management was only $85 \mathrm{~kg} \mathrm{ha}^{-1} \mathrm{yr}^{-1}$ greater than that of the $7.6 \mathrm{~cm}$ cutting management. Frequency of defoliation did not appear to affect herbage accumulation; however, the intensity of defoliation did directly affected herbage accumulation.

The differences in CP, NDF and ADF concentrations between the 2.5 and $7.6 \mathrm{~cm}$ cutting managements varied by only 2 to $3 \%$ in both years of the study. The quantity and quality of forage are both very important. When quantity was lower, quality was higher, giving a "balance." Herbage accumulation was greatest at the $2.5 \mathrm{~cm}$ cutting management; however, herbage quality was highest at the $7.6 \mathrm{~cm}$ cutting management. Therefore, the results indicate that there may be no differences between cutting managements.

Crude protein concentration was the only herbage characteristic that was increased by the addition of $\mathrm{N}$ fertilizer. The concentration of $\mathrm{CP}$ in herbage treated with the no, medium and high $\mathrm{N}$ was $17.6,18.5$ and $18.7 \%$, respectively. Therefore, the effect of $\mathrm{N}$ on $\mathrm{CP}$ was not drastic. The small response to the $\mathrm{N}$ fertilizer may have been the result of low rainfall. The amount of rainfall also influenced each of the pasture production and quality indicators, giving large differences in results between 1999 and 
2000. Quantity and quality of herbage were both greater in 2000, when rainfall was much higher. Approximately $20 \mathrm{~cm}$ more rainfall was recorded from May to August 2000 compared to May to August 1999. While N fertilization did increase the quality of the herbage slightly, the effects of the $\mathrm{N}$ fertilization did seem to be dependent on the rainfall, and is difficult to predict. In addition, the timing of the $\mathrm{N}$ fertilization applications may not have complimented the growth of the pasture well.

Compared to the lower two sampling depths, the root volume, dry weight and length were much greater in the upper $0.0-5.1 \mathrm{~cm}$ of the soil. This is a result of the root growth patterns of Kentucky bluegrass and white clover. Root volume, dry weight and length were all greater in 2000 than in 1999, due to the below normal rainfall in 1999. Also, root growth was usually highest in the spring.

In the upper $0.0-5.1 \mathrm{~cm}$ sampling depth, root volume and dry weight were increased by $\mathrm{N}$ fertilization. The root growth of patterns of Kentucky bluegrass and white clover naturally result in greater root growth at this depth. Roots generally proliferate in areas of higher nutrient concentrations, and the uptake of $\mathrm{N}$ is directly proportional to the amount of roots in a given area. Therefore, since the $\mathrm{N}$ fertilizer was applied to the surface of the soil and the amount of roots in the upper $0.0-5.1 \mathrm{~cm}$ of the soil was large, the roots took up most of the applied $\mathrm{N}$ in the upper sampling depth.

Plants cut to $2.5 \mathrm{~cm}$ had lower root volume, dry weight and length in the $0.0-5.1$ $\mathrm{cm}$ sampling depth than plants cut to 5.1 or $7.6 \mathrm{~cm}$. More severe defoliation probably caused some roots to die and root growth to stop. The result would be a decrease in root volume, dry weight and length. 
In 1999 and 2000, soil treated with the medium and high $\mathrm{N}$ fertilization levels had higher soil $\mathrm{NO}_{3}{ }^{-}$concentrations than soil to which no $\mathrm{N}$ was applied. The roots in the upper $5.1 \mathrm{~cm}$ of the soil may have taken up most of the $\mathrm{N}$ applied to the surface, leaving little $\mathrm{N}$ to leach to the depth of the ion transfer membrane. The low rainfall in 1999 and late summer of 2000 seemed to decrease the amount of $\mathrm{NO}_{3}^{-}$that desorbed to the ion transfer membrane. The low rainfall during these periods may be the reason why such large differences were found between 1999 and 2000, and no differences in soil $\mathrm{NO}_{3}{ }^{-}$ concentration were found between the medium and high $\mathrm{N}$ treatments. In addition, the lower abundance of roots in the upper $5.1 \mathrm{~cm}$ of the soil could have contributed to the higher soil $\mathrm{NO}_{3}{ }^{-}$concentrations found in the soil under plants cut to $2.5 \mathrm{~cm}$. Because severe defoliation decreases root quantity, fewer roots were available to take up $\mathrm{NO}_{3}{ }^{-}$ from the soil. Therefore, the $\mathrm{NO}_{3}{ }^{-}$leached through the soil profile and was available for the desorbtion to the ion transfer membrane. 


\section{LITERATURE CITED}

Aber, J. D., J. M. Melillo, K. J. Nadelhoffer, C. A. McClaugherty, and J. Pastor. 1985. Fine root turnover in forest ecosystems in relation to quantity and form of nitrogen availability: a comparison of two methods. Oecologia 66:317-321.

Andrews, R. E., and E. I. Newman. 1970. Root density and competition for nutrients. Oecol. Plant 5:319-334.

Ankom Technology. 1997a. Method for determining neutral detergent fiber. Ankom Technology.

Ankom Technology. 1997b. Method for determining acid detergent fiber. Ankom Technology.

Austenson, H. M., F. R. Murdock, A. S. Hodson, and T. S. Russell. 1959. Regression of milk production on forage production and forage consumption. Agron. J. 51:648650 .

Bassman, J. H., and D. I. Dickmann. 1985. Effects of defoliation in the developing leaf zone on young Populus $x$-euramericana plants. II. Distribution of 14-C photosynthate after defoliation. For. Sci. 31:358-366.

Baylor, J. E. 1974. Satisfying the nutritional requirements of grass-legume mixtures. p. 171-188. In D. A. Mays (ed.) Forage fertilization. ASA CSSA SSSA, Madison, WI.

Belanger, G., F. Gastal, and F. R. Warembourg. 1992. The effects of nitrogen fertilization and the growing season on carbon partitioning in a sward of tall fescue (Festuca arundinacea Schreb.). Ann. Bot. 70:239-244.

Benedict, H. M., and G. B. Brown. 1944. The growth and carbohydrate responses of Agropyron smithii and Bouteloua gracilis to changes in nitrogen supply. Plant Physiol. 19:481-494.

Blaser, R. E., R. C. Hammes, Jr., H. T. Bryant, C. M. Kincaid, W. H. Skrdla, T. H. Taylor, and W. L. Griffith. 1956. The value of forage species and mixtures for fattening steers. Agron. J. 48:508-513.

Bolan, N. S. 1991. A critical review on the role of mycorrhizal fungi in the uptake of phosphorus by plants. Plant Soil 134:189-207. 
Boot, R. G. A., and Mensink, M. 1990. Size and morphology of root systems of perennial grasses from contrasting habitats as affected by nitrogen supply. Plant Soil 129:291-299.

Brown, E. M. 1943. Seasonal variations in the growth and chemical composition of Kentucky bluegrass. Missouri Agr. Exp. Sta. Bull. 360.

Bruand, A., I. Cousin, B. Nicoullaud, O. Duval, and J. C. Begon. 1996. Backscattered electron scanning images of soil porosity for analysing soil compaction around roots. Soil Sci. Soc. Am. J. 60:895-901.

Bryan, W. B., E. C. Prigge, M. Lasat, T. Pasha, D. J. Flaherty, and J. Lozier. 2000. Productivity of Kentucky bluegrass pasture grazed at three heights and two intensities. Agron. J. 92:30-35.

Bryan W. B., W. V. Thayne, and E. C. Prigge. 1989. Use of a disk meter to evaluate continuously grazed pastures. J. Agron. Crop Sci. 163:44-48.

Caldwell, M. M. 1987. Competition between root systems in natural communities. p. 167-185. In P. J. Gregory, J. V. Lake, and D. A. Rose (ed.) Root Development and Function. Semin. Ser. Exp. Biol.

Caradus, J. R. 1990. The structure and function of white clover root systems. Adv. Agron. 43:1-46.

Carroll, J. C., and F. A. Welton. 1939. Effect of heavy and late applications of nitrogenous fertilizer on the cold resistance of Kentucky bluegrass. Plant Physiol. 14:297-308.

Carter, L. P., and J. M. Scholl. 1962. Effectiveness of inorganic nitrogen as a replacement for legumes grown in association with forage grasses. I. Dry matter production and botanical composition. Agron. J. 54:161-165.

Churchill, B. R. 1947. Productiveness of bromegrass strains from different regions when grown in pure stands and in mixture with alfalfa in Michigan. J. Am. Soc. Agron. 39:750-761.

Clark, N. A., J. I. Leslie, and R. W. Hemken. 1966. Comparison of nitrogen fertilized with a grass-legume mixture as pasture for dairy cows. I. Dry matter production, carrying capacity, and milk production. Agron. J. 58:280-282.

Collins, A., and D. W. Allinson. 1999. Use of anion exchange membranes to assess nitrogen needs of perennial grasslands. Commun. Soil Sci. Plant Anal. 30:2267-2282. 
Cosper, H. R., and J. R. Thomas. 1961. Influence of supplemental run-off water and fertilizer on production and chemical composition of native forages. J. Range Manage. 14:292-297.

Coupland, R. T., N. A. Skoglund, and A. J. Heard. 1960. Effects of grazing in the Canadian mixed prairie. p. 212-215. In Proc. 8th International Grassland Cong.

Crick, J. C., and J. P. Grime. 1987. Morphological plasticity and mineral nutrient capture in two herbaceous species in contrasted ecology. New Phytol. 107:403414.

Darrah, P. R. 1993. The rhizospere and plant nutrition: A quantitative approach. Plant Soil 155/156:1-20.

Dawson, K. P., and J. C. Ryden. 1985. Uptake of fertilizer and soil nitrogen by ryegrass swards during spring and mid-season. Fert. Res. 6:177-188.

Dexter, A. R. 1987. Compression of soil around roots. Plant Soil 97:401-406.

Dexter, S. T. 1956. The evaluation of crop plants for winterhardiness. Adv. Agron. 8:203-239.

Donald, C. M. 1963. Competition among crop and pasture plants. Adv. Agron. 15:1114.

Dovel, R. L. 1996. Cutting height effects on wetland meadow forage yield and quality. J. Range Manage. 49:151-156.

Drew, M. C. 1975. Comparison of the effects of a localized supply of phosphate, nitrate, ammonium and potassium on the growth of the seminal root system, and the shoot, in barley. New Phytol. 75:479-490.

Drew, M. C., and P. H. Nye. 1969. The supply of nutrient ions by diffusion to plant roots in soil. II. The effect of root hairs on the uptake of potassium by roots of ryegrass (Lolium multiflorum). Plant Soil 31:407-424.

Dubach, M., and M. P. Russelle. 1994. Forage legume roots and nodules and their role in nitrogen transfer. Agron. J. 86:259-266.

Elder, W. C., and H. F. Murphy. 1961. Grazing characteristics and clipping responses of bermudagrass. Oklahoma Agr. Exp. Sta. Bul. B-577.

Evans, A. M. 1976. Clovers. p. 175-179. In N. W. Simmons (ed.) Evolution of crop plants. Longmans, London. 
Ewing, R. P., and T. C. Kaspar. 1995. Accurate perimeter and length measurement using an edge chord algorithm. J. Comput. Assisted Microsc. 7:91-100.

Field, C. 1983. Allocating leaf nitrogen for the maximization of carbon gain: Leaf age as a control on the allocation programme. Oecologia 56:341-347.

Forbes, R. M., and W. P. Garrigus. 1948. Application of a lignin ratio technique to the determination of the nutrient intake of grazing animals. J. Anim. Sci. 7:373-382.

Gahoonia, T. S., N. Claassen, and A. Jungk. 1992. Mobilization of phosphate in different soils by ryegrass supplied with ammonium or nitrate. Plant Soil 140:241-248.

Gardner, W. R. 1964. Relation of root distribution to water uptake and availability. Agron. J. 56:41-45.

Gastal, F., and G. Belanger. 1993. The effects of nitrogen fertilization and the growing season on photosynthesis of field-grown tall fescue (Festuca arundinacea Schreb.) canopies. Ann. Bot. 72:401-408.

Gist, G. R., and R. M. Smith. 1948. Root development of several common forage grasses to a depth of eighteen inches. J. Am. Soc. Agron. 40:1036-1042.

Gold, W. G., and M. M. Caldwell. 1989. The effects of spatial pattern of defoliation on regrowth of a tussock grass. I. Growth responses. Oecologia 80:289-296.

Graber, L. F. 1933. Competitive efficiency and productivity of bluegrass with partial defoliation at two levels of cutting. J. Am. Soc. Agron. 25:326-333.

Hamza, M. A., and L. A. G. Alymore. 1992. Soil solute concentration and water uptake by single lupin and radish plant roots. I. Water extraction and solute accumulation. Plant Soil 145:187-196.

Hanson, A. A., and F. V. Juska. 1961. Winter root activity in Kentucky bluegrass (Poa pratensis L.). Agron. J. 53:372-374.

Haratt, C. E., H. P. Kortschak, and G. O. Burr. 1964. Effects of defoliation, deradication and darkening the blade upon translocation of $\mathrm{C}_{14}$ in sugarcane. Plant Physiol. 39:15-22.

Hart, R. H., and G. W. Burton. 1965. Effect of row spacing, seeding rate, and nitrogen fertilization on forage yield and quality of Gahi-1 pearlmillet. Agron. J. 57:376378.

Havill, D. C., J. A. Lee, and J. De-Felice. 1977. Some factors limiting nitrate utilization in acidic and calcareous grassland. New Phytol. 78:649-659. 
Haynes, R. J. 1990. Active ion uptake and maintenance of cation-anion balance: A critical examination of their role in regulating rhizosphere $\mathrm{pH}$. Plant Soil 126:247-264.

Heinemann, W. W., and R. W. VanKeuren. 1958. A comparison of grass-legume mixtures, and grasses under irrigation as pasture for sheep. Agron. J. 50:189192.

Hinsinger, P. 1998. How do plant roots acquire mineral nutrients? Chemical processes involved in the rhizospere. Adv. Agron. 64:225-265.

Hirose, T., and M. J. A. Werger. 1987. Maximising daily canopy photosynthesis with respect to the leaf nitrogen allocation pattern in the canopy. Oecologia 72:520526.

Hodgkinson, K. C. 1974. Influence of partial defoliation on photosynthesis, photorespiration and transpiration by lucerne leaves of different ages. Aust. J. Agric. Res. 25:561-578.

Hodgkinson, K. C., N. G. Smith, and G. E. Miles. 1972. The photosynthetic capacity of stubble leaves and their contribution to growth of the lucerne plant after high level cutting. Aust. J. Agric. Res. 23:225-238.

Holt, E. C., and F. L. Fisher. 1960. Root development of coastal Bermudagrass with high nitrogen fertilization. Agron. J. 52:593-595.

Horneck, D. A, and R. O. Miller. 1998. Determination of total nitrogen in plant tissue. p. 75-83. In Y. P. Kalra (ed.) Handbook of reference methods for plant analysis. CRC Press, New York, NY.

Howell, J. H., and G. A. Jung. 1965. Cold resistance of 'Potomac' orchardgrass as related to cutting management, nitrogen fertilization, and mineral levels in the plant sap. Agron. J. 57:525-529.

Ionics. 1990. Properties and characteristics of anion transfer membranes type 204-U386. Bul. AR 204 O-D. Ionics, Watertown, MA

Jarvis, S. C., and J. H. MacDuff. 1989. Nitrate nutrition of grasses from steady-state supplies in flowing solution culture following nitrate deprivation and/or defoliation. I. Recovery of uptake and growth and their interactions. J. Exp. Bot. 40:965-975.

Jarvis, S. C., and A. D. Robson. 1983. The effects of nitrogen nutrition of plants on the development of acidity in Western Australian soils. I. Effects with subterranean clover grown under leaching conditions. Aust. J. Agric. Res. 34:341-353. 
Johnson, B. J., and R. N. Carrow. 1988. Frequency of fertilizer applications and centipedegrass performance. Agron. J. 80:925-929.

Johnson. B. J., R. N. Carrow, and R. E. Burns. 1988. Centipedegrass decline and recovery as affected by fertilizer and cultural treatments. Agron. J. 80:479-486.

Jones, Jr., J. B. 1991. Kjeldahl method for nitrogen (N) determination. Micro-Macro Publishing, Athens, GA.

Jones, M. B. 1967. Forage and nitrogen production by subclover-grass and nitrogen fertilized California grassland. Agron. J. 59:459-461.

Jordon, R. M., and W. F. Wedin. 1961. Lamb production as affected by forage mixture and grazing management of perennial pastures. J. Anim. Sci. 20:898-902.

Kang, J. H., and G. E. Brink. 1995. White clover morphology and physiology in response to defoliation. Crop Sci. 35:264-269.

Kaspar, T. C., and R. P. Ewing. 1997. ROOTEDGE: Software for measuring root length from desktop scanner images. Agron. J. 89:932-940.

Kennedy, W. K., and M. B. Russell. 1948. Relationship of top growth, root growth, and apparent specific gravity of the soil under different clipping treatments of a Kentucky bluegrass-wild white clover pasture. J. Am. Soc. Agron. 40:535-540.

Knox, F. E., G. W. Burton, and D. M. Baird. 1958. Effect of nitrogen rate and clipping frequency upon lignin content and digestibility of coastal bermudagrass. Agric. Food Chem. 6:217-219.

Kolesnikov, V. 1971. The root system of fruit trees. Izdatelstvo Mir. Moscow.

Laidlaw, A. S., P. Christie, and H. W. Lee. 1996. Effect of white clover cultivar on apparent transfer of nitrogen from clover to grass and estimation of relative turnover rates of nitrogen in roots. Plant Soil 179:243-253.

Lamond, M., R. Tavakol, and A. Riedacker. 1983. Effect of blocking the tip of the tap root on root morphogenesis of oak (Quercus robur) seedlings. Ann. Sci. For. 40:227-250.

Lorenz, R. J., and G. A. Rogler. 1966. Root growth of Northern plains grasses under various fertilizer and management treatments. p. 1-10. In Proc. Am. Forage and Grassl. Council. 1-4 Feb, New Orleans, Louisiana.

Luo, Y, P. A. Meyerhoff, and R. S. Loomis. 1995. Seasonal pattern and vertical distribution of fine roots of alfalfa (Medicago sativa L.). Field Crops Res. 40:119-127. 
Lyr, H., and G. Hoffman. 1967. Growth rates and growth periodicity of tree roots. Int. Rev. For. Res. 2:181-206.

MacKlon, A. E. S., L. A. Mackie-Dawson, C. A. Shand, and A. Sim. 1996. Soil water effects on growth and nutrition in upland pastures. J. Range Manage. 49:251256.

Marshall, C., and G. R. Sagar. 1965. The influence of defoliation on the distribution of assimilates in Lolium multiflorum Lan. Ann. Bot. 32:715-719.

Mason, W., and L. Lachance. 1983. Effects of initial harvest date on dry matter yield, in vitro dry matter digestibility, and protein in timothy, tall fescue, reed canary grass, and Kentucky bluegrass. Can. J. Sci. 63:675-685.

McLaren, J. B., R. J. Carlisle, H. A. Fribourg, and J. M. Bryan. 1983. Bermudagrass, tall fescue, and orchardgrass pasture combinations with clover or $\mathrm{N}$ fertilization for grazing steers. I. Forage growth and consumption, and animal performance. Agron. J. 75:587-592

Moore, A. W., and H. F. Rhodes. 1966. Soil conditions and root distribution in two wet meadows of the Nebraska sandhills. Agron. J. 58:563-566.

Mortimer, G. B., and H. L. Ahlgren. 1936. Influence of fertilization, irrigation, and stage and height of cutting on yield and composition of Kentucky bluegrass (Poa pratensis L.). J. Am. Soc. Agron. 28:515-533.

Nie, Z. N., A. D. Mackay, I. Valentine, D. J. Barker, and J. Hodgson. 1997. Influence of pastoral fallow on plant root growth and soil physical and chemical characteristics in a hill pasture. Plant Soil 197:201-208.

Nuttall, W. F. 1980. Effect of nitrogen and phosphorus fertilizers on a bromegrass and alfalfa mixture grown under two systems of pasture management. II. Nitrogen and phosphorus uptake and concentration in herbage. Agron. J. 72:295-298.

Nye. P. H. 1981. Changes of $\mathrm{pH}$ across the rhizospere induced by roots. Plant Soil 61:7-26.

Nye, P. H. 1986. Acid-base changes in the rhizospere. Adv. Plant Nutr. 2:129-153.

Ourry, A., J. Bigot, and J. Boucaud. 1988. Nitrogen mobilisation from stubble and roots during regrowth of defoliated perennial ryegrass. J. Exp. Bot. 39:803-809.

Paine, L. K., D. Undersander, and M. D. Casler. 1999. Pasture growth, production, and quality under rotational and continuous grazing management. J. Prod. Agric. 12:569-577. 
Pare, T., E. G. Gregorich, and B. H. Ellert. 1995. Comparison of soil nitrate extracted by potassium chloride and absorbs on an anion exchange membrane in situ. Commun. Soil Sci. Plant Anal. 26:883-898.

Parsons, J. L. 1958. Nitrogen fertilization of alfalfa-grass mixtures. Agron. J. 50:593594.

Pierre, W. H., J. H. Longwell, R. R. Robinson, G. M. Browning, I. McKeever, and R. F. Copple. 1937. West Virginia pastures: type of vegetation, carrying capacity and soil properties. West Virginia Agr. Exp. Sta. Bull. 280.

Pons, T. L., F. Schieving, T. Hirose, and M. J. A. Werger. 1989. Optimization of leaf nitrogen allocation for canopy photosynthesis in Lysimachia vulgaris. p. 175186. In H. Lambers, M. L. Cambridge, H. Konings, and T. L. Pons (eds.) Causes and Consequenses of Variation in Growth Rate and Productivity of Higher Plants. SPB Academic Publishing, The Hague, The Netherlands.

Raese, J. T., and A. M. Decker. 1966. Yields, stand persistence, and carbohydrate reserves of perennial grasses as influenced by spring harvest stage, stubble height, and nitrogen fertilization. Agron. J. 58:322-326.

Rayburn, E. B. and S. B. Rayburn. 1998. A standardized plate meter for estimating pasture mass in on-farm research trials. Agron. J. 90:238-241.

Reid, D., and M. E. Castle. 1965. The response of grass/clover and pure-grass to irrigation and fertilizer nitrogen treatment. 2. Clover and fertilizer nitrogen effects. J. Agr. Sci. (Camb.) 65:109-119.

Richards, J. H. 1993. Physiology of plants recovering from defoliation. p. 85-94. In Proc. XVII Intern. Grassl. Congr. 8-21 Feb. 1993. Palmerston North, New Zealand.

Riley, D., and S. A. Barber. 1971. Effect of ammonium and nitrate fertilization on phosphorous uptake as related to root-induced $\mathrm{pH}$ changes at the root-soil interface. Soil Sci. Soc. Am. Proc. 35:301-306.

Robinson, R. R., and V. G. Sprague. 1946. The clover populations and yields of a Kentucky bluegrass sod as affected by nitrogen fertilization, clipping treatments, and irrigation. J. Am. Soc. Agron. 39:107-116.

Ryle, G. J. A., and C. E. Powell. 1975. Defoliation and regrowth in the graminaceous plant: the role of current assimilate. Ann. Bot. 39:297-310.

Ryle, G. J. A., C. E. Powell, and A. J. Gordon. 1986. Defoliation in white clover: nodule metabolism, nodule growth and maintenance, and nitrogenase functioning during growth and regrowth. Ann. Bot. 57:263-271. 
SAS Institute. 1990. SAS User's Guide: Statistics. 4th ed. SAS Inst., Cary, NC.

Sanderson, M. A., D. W. Stair, and M. A. Hussey. 1997. Physiological and morphological responses of perennial forages to stress. Adv. Agron. 59:171-224.

Schuster, J. L. 1964. Root development of native plants under three grazing intensities. Ecology 45:63-70.

Sheard, R. W. 1970. Characterization of food reserves as a basis for timing nitrogen applications for timothy (Phleum pratense L.). p. 570-574. In Proc. XI Intern. Grassl. Congr., Surfer's Paradise, Australia.

Smucker, A. J. M. 1984. Carbon utilization and losses by plant root systems. p. 27-46. In Symposium on Roots, Nutrient and Water Influx, and Plant Growth. ASA Spec. Publ. Am. Soc. Agron. 28 Nov.-3 Dec 1982. Anaheim, CA.

Sprague, H. B. 1933. Root development of perennial grasses and its relation to soil conditions. Soil Sci. 36:189-209.

Stuckey, I. H. 1941. Seasonal growth of grass roots. Am. J. Bot. 28:486-491.

Swift, R. W., W. H. James, L. F. Marcy, R. F. Elliott, V. F. Smith, and H. W. Higbee. 1948. Monthly yields and composition of herbage composed of Kentucky bluegrass, Poa pratensis L., and white clover, Trifolium repens L., as affected by fertilizer treatments. Am. Soc. Agron. J. 40:1051-1060.

Thornton, B., and P. Millard. 1996. Effects of severity of defoliation on root functioning in grasses. J. Range Manage. 49:443-447.

Vance, C. P., and G. H. Heichel. 1981. Nitrate assimilation during vegetative regrowth of alfalfa. Plant Physiol. 68:1052-1056.

Vogt, K. A., D. A. Publicover, J. Bloomfield, J. M. Perez, D. J. Vogt, and W. L. Silver. 1993. Belowground responses as indicators of environmental change. Environ. Exp. Bot. 33:189-205.

Washko, J. B. 1963. Fertilizer experiments with summer annual forage crops. Pennsylvania Agr. Exp. Sta. Prog. Rep. 243.

Weaver, J. E. 1930. Underground plant development in its relation to grazing. Ecology 11:543-557.

Webster, J. E., J. W. Hogan, and W. C. Elder. 1965. Effect of rate of ammonium nitrate fertilization and time of cutting upon selected chemical components and the in vitro rumen digestion of bermudagrass forage. Agron. J. 57:323-325. 
Wedin, W. F. 1974. Fertilization of cool-season grasses. p. 95-118. In D. A. Mays (ed.) Forage Fertilization. ASA CSSA SSSA, Madison, WI.

Weinberger, P., and D. Yee. 1984. The influence of nitrogen sources on root-mediated changes in substrate $\mathrm{pH}$. Can. J. Bot. 62:161-162.

Whitehead, D. C. 1982. Yield of white clover (Trifolium repens L.) and its fixation of nitrogen as influenced by nutritional and soil factors under controlled environment conditions. J. Sci. Food Agric. 33:1227-1235.

Wilkinson, S. R., and C. F. Gross. 1964. Competition for light, soil moisture and nutrients during ladino clover establishment in orchardgrass sod. Agron. J. 56:389-392.

Williams, B. C. 1962. Rates of fertilizer for forage crops. New Mexico Agr. Exp. Sta. Res. Rep. 71.

Williams, M. 1967. Clover boosts calf production. Univ. Florida Res. Rep. 12 (4): 4-5.

Williams, M. J., and A. C. Hammond. 1999. Rotational vs. continuous intensive stocking management of bahiagrass pasture for cows and calves. Agron. J. 91:11-16.

Wolf, D. D. and D. Smith. 1964. Yield and persistence of several legume-grass mixtures as affected by cutting frequency and nitrogen fertilization. Agron. J. 56:130-133.

Ziadi, N, and R. R. Simard. 1996. In situ measurements of $\mathrm{NO}_{3}-\mathrm{N}$ with anion exchange resins. p 315. In Agron. Abstr. Am. Soc. Agron., Madison, WI. 


\section{LIST OF APPENDICES}

$\begin{array}{ll}\text { Appendix } & \text { Page }\end{array}$

A. Analysis of variance of annual herbage accumulation.................... 89

B. Analysis of variance for CP content of herbage annual mass................ 90

C. Analysis of variance for CP content of herbage harvested in 2000, meaned within harvest dates.

D. Analysis of variance for CP yield of herbage, summed over harvest dates

E. Analysis of variance for CP yield means within harvest period in 2000 .

F. Analysis of variance for NDF and ADF content of herbage, averaged over harvest dates

G. Analysis of variance for NDF and ADF content of herbage harvested in 2000, meaned within harvest dates.

H. Analysis of variance for root volume at each sampling depth................... 96

I. Analysis of variance for root dry weight at each sampling depth.............. 97

J. Analysis of variance for root length at each sampling depth................... 98

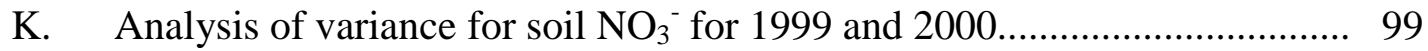

L. Analysis of variance for soil $\mathrm{pH}$ and available soil $\mathrm{P}, \mathrm{K}, \mathrm{Ca}$ and $\mathrm{Mg}$ in experimental plots in 1999 and 2000. 


\section{Appendix Table A}

\section{Analysis of variance for annual herbage accumulation}

\begin{tabular}{|c|c|c|}
\hline \multirow[b]{2}{*}{ Source } & \multicolumn{2}{|c|}{ Herbage accumulation } \\
\hline & df & $\begin{array}{c}\text { Analysis of variance } \\
\text { partial sums of squares }\end{array}$ \\
\hline Block & 3 & 1080417 \\
\hline $\mathrm{N}$ & 2 & 1785564 \\
\hline none vs. medium and high & 1 & 1752690 \\
\hline medium vs. high & 1 & 32874 \\
\hline Cutting management & 2 & $20633794 * * *$ \\
\hline $2.5 \mathrm{~cm}$ vs. 5.1 and $7.6 \mathrm{~cm}$ & 1 & $20525042 * * *$ \\
\hline $5.1 \mathrm{~cm}$ vs. $7.6 \mathrm{~cm}$ & 1 & 108753 \\
\hline $\mathrm{N} x$ Cutting management & 4 & 1220244 \\
\hline Error a & 24 & 10958763 \\
\hline Year & 1 & $75433660 * * *$ \\
\hline $\mathrm{N} x$ year & 2 & 1438977 \\
\hline Cutting management $\mathrm{x}$ year & 2 & $2418419 *$ \\
\hline $\mathrm{N} x$ Cutting management $\mathrm{x}$ year & 4 & $5800043 * *$ \\
\hline Error b & 27 & 6395350 \\
\hline
\end{tabular}

Note: Significance of F test. * ${ }^{*} \mathrm{P}<0.05 ; * *, \mathrm{P}<0.01$; *** $\mathrm{P}<0.0001$. 


\section{Appendix Table B}

Analysis of variance for CP content of herbage annual means

\begin{tabular}{|c|c|c|}
\hline \multirow[b]{2}{*}{ Source } & \multicolumn{2}{|r|}{$\mathbf{C P}$} \\
\hline & df & $\begin{array}{l}\text { Analysis of variance of } \\
\text { partial sums of squares }\end{array}$ \\
\hline Block & 3 & 5.70 \\
\hline $\mathrm{N}$ & 2 & 16.45 \\
\hline none vs. medium and high & 1 & $15.89 *$ \\
\hline medium vs. high & 1 & 0.56 \\
\hline Cutting management & 2 & $58.20 * *$ \\
\hline $2.5 \mathrm{~cm}$ vs. 5.1 and $7.6 \mathrm{~cm}$ & 1 & $38.60 * *$ \\
\hline $5.1 \mathrm{~cm}$ vs. $7.6 \mathrm{~cm}$ & 1 & $19.60 *$ \\
\hline $\mathrm{N} x$ Cutting management & 4 & 20.88 \\
\hline Error a & 24 & 67.97 \\
\hline Year & 1 & $60.05 * * *$ \\
\hline $\mathrm{Nx}$ Year & 2 & $19.99 * *$ \\
\hline Cutting management $\mathrm{x}$ Year & 2 & $15.63 * *$ \\
\hline $\mathrm{N} x$ Cutting management $\mathrm{x}$ Year & 4 & $15.80^{*}$ \\
\hline Error b & 27 & 32.39 \\
\hline
\end{tabular}

Note: Significance of $\mathrm{F}$ test. $*, \mathrm{P}<0.05 ; * *, \mathrm{P}<0.01$; *** $\mathrm{P}<0.0001$. 


\section{Appendix Table C}

Analysis of variance for CP content of herbage harvested in 2000, meaned within harvest period

\begin{tabular}{lcc}
\hline & & CP \\
\cline { 2 - 3 } \multicolumn{1}{c}{ Source } & & $\begin{array}{c}\text { Analysis of variance of } \\
\text { partial sums of squares }\end{array}$ \\
\hline Block & df & 25.89 \\
N & 3 & 4.40 \\
none vs. medium and high & 2 & 0.09 \\
medium vs. high & 1 & 4.31 \\
Cutting management & 1 & $182.06^{* * *}$ \\
2.5 cm vs. 5.1 and 7.6 cm & 2 & $159.14^{* * *}$ \\
5.1 cm vs. 7.6 cm & 1 & $22.93^{*}$ \\
N x Cutting management & 1 & 5.01 \\
Error a & 4 & 72.58 \\
& 24 & $164.01^{* * *}$ \\
Harvest period & & $156.03^{* * *}$ \\
Harvest period 1 vs. harvest periods 2 and 3 & 2 & $7.98^{* *}$ \\
Harvest period 2 vs. harvest period 3 & 1 & $11.56^{*}$ \\
N x Harvest period & 1 & $104.35^{* * *}$ \\
Cutting management x Harvest period & 4 & $24.11^{*}$ \\
N x Cutting management x Harvest period & 4 & 59.04 \\
Error b & 8 &
\end{tabular}

Note: *, $\mathrm{P}<0.05 ; * *, \mathrm{P}<0.01 ; * * * \mathrm{P}<0.0001$; Other interaction are NS 


\section{Appendix Table D}

\section{Analysis of variance for CP yield of herbage, summed over harvest dates}

\begin{tabular}{|c|c|c|}
\hline \multirow[b]{2}{*}{ Source } & \multicolumn{2}{|r|}{ CP yield } \\
\hline & df & $\begin{array}{l}\text { Analysis of variance of } \\
\text { partial sums of squares }\end{array}$ \\
\hline Block & 3 & 62137.40 \\
\hline $\mathrm{N}$ & 2 & 84840.85 \\
\hline none vs. medium and high & 1 & 84464.03 \\
\hline medium vs. high & 1 & 376.82 \\
\hline Cutting management & 2 & $401063.21 * *$ \\
\hline $2.5 \mathrm{~cm}$ vs. 5.1 and $7.6 \mathrm{~cm}$ & 1 & $363168.06 * *$ \\
\hline $5.1 \mathrm{~cm}$ vs. $7.6 \mathrm{~cm}$ & 1 & 37895.15 \\
\hline $\mathrm{N} x$ Cutting management & 4 & 75901.62 \\
\hline Error a & 24 & 588286.93 \\
\hline Year & 1 & $3032557.07 * * *$ \\
\hline $\mathrm{N} x$ Year & 2 & $84142.87 *$ \\
\hline Cutting management $\mathrm{x}$ Year & 2 & 27151.16 \\
\hline $\mathrm{N} x$ Cutting management $\mathrm{x}$ Year & 4 & $259106.31 * *$ \\
\hline Error b & 27 & 296965.53 \\
\hline
\end{tabular}

Note: Significance of $\mathrm{F}$ test. *, $\mathrm{P}<0.05$; **, $\mathrm{P}<0.01$; *** $\mathrm{P}<0.0001$. 


\section{Appendix Table E}

Analysis of variance for CP yield means within harvest period in 2000

\begin{tabular}{lcc}
\hline & \multicolumn{2}{c}{ CP yield } \\
\cline { 2 - 3 } \multicolumn{1}{c}{ Source } & & $\begin{array}{c}\text { Analysis of variance of } \\
\text { partial sums of squares }\end{array}$ \\
\hline Block & df & 11596.18 \\
N & 3 & 1574.59 \\
none vs. medium and high & 2 & 342.82 \\
medium vs. high & 1 & 1231.77 \\
Cutting management & 1 & $392564.66^{* * *}$ \\
2.5 cm vs. 5.1 and 7.6 cm & 2 & $391964.62^{* * *}$ \\
5.1 cm vs. 7.6 cm & 1 & 600.05 \\
N x Cutting management & 1 & 28066.34 \\
Error a & 4 & 93820.58 \\
& 24 & 4658.11 \\
Harvest period & & 1265.34 \\
Harvest period 1 vs. harvest periods 2 and 3 & 2 & 3392.76 \\
Harvest period 2 vs. harvest period 3 & 1 & 5887.44 \\
N x Harvest period & 1 & $76049.34 * * *$ \\
Cutting management x Harvest period & 4 & 24453.98 \\
N x Cutting management x Harvest period & 4 & 78476.13 \\
Error b & 8 & \\
\hline
\end{tabular}

Note: Significance of $\mathrm{F}$ test. $*, \mathrm{P}<0.05 ; * *, \mathrm{P}<0.01$; *** $\mathrm{P}<0.0001$. 


\section{Appendix Table F}

Analysis of variance for NDF and ADF content of herbage, averaged over harvest dates

\begin{tabular}{|c|c|c|c|}
\hline \multirow[b]{2}{*}{ Source } & \multirow[b]{2}{*}{ df } & NDF & ADF \\
\hline & & $\begin{array}{l}\text { Analysis of variance of } \\
\text { partial sums of squares }\end{array}$ & $\begin{array}{l}\text { Analysis of variance of } \\
\text { partial sums of squares }\end{array}$ \\
\hline Block & 3 & $69.38 * *$ & 23.65 \\
\hline $\mathrm{N}$ & 2 & 0.85 & 18.01 \\
\hline none vs. medium and high & 1 & 0.33 & 8.34 \\
\hline medium vs. high & 1 & 0.52 & 9.67 \\
\hline Cutting management & 2 & $133.65 * * *$ & $176.36 * * *$ \\
\hline $2.5 \mathrm{~cm}$ vs. 5.1 and $7.6 \mathrm{~cm}$ & 1 & $53.27 * *$ & $144.94 * * *$ \\
\hline $5.1 \mathrm{~cm}$ vs. $7.6 \mathrm{~cm}$ & 1 & $80.37 * *$ & $31.42 * *$ \\
\hline $\mathrm{N} x$ Cutting management & 4 & 9.93 & 27.48 \\
\hline Error a & 24 & 100.36 & 81.16 \\
\hline Year & 1 & $240.42 * * *$ & $100.32 * * *$ \\
\hline Nx Year & 2 & 7.96 & $14.87 * *$ \\
\hline Cutting management x Year & 2 & $25.75 * *$ & $10.74 * *$ \\
\hline $\mathrm{N} x$ Cutting management $\mathrm{x}$ Year & 4 & 5.16 & 6.34 \\
\hline Error b & 27 & 61.74 & 22.33 \\
\hline
\end{tabular}

Note: Significance of $\mathrm{F}$ test. * $\mathrm{P}<0.05 ; * *, \mathrm{P}<0.01 ; * * * \mathrm{P}<0.0001$. 


\section{Appendix Table G}

\section{Analysis of variance for NDF and ADF content of herbage harvested in 2000, meaned within harvest period}

\begin{tabular}{lccc}
\hline & & NDF & ADF \\
\cline { 2 - 4 } \multicolumn{1}{c}{ Source } & & $\begin{array}{c}\text { Analysis of variance } \\
\text { of partial sums of } \\
\text { squares }\end{array}$ & $\begin{array}{c}\text { Analysis of variance } \\
\text { of partial sums of } \\
\text { squares }\end{array}$ \\
\hline Block & 3 & $69.45 *$ & 31.72 \\
N & 2 & 22.12 & 9.59 \\
none vs. medium and high & 1 & 20.42 & 1.10 \\
medium vs. high & 1 & 1.70 & 8.49 \\
Cutting management & 2 & $501.94 * * *$ & $810.36 * * *$ \\
2.5 cm vs. 5.1 and 7.6 cm & 1 & $473.34 * * *$ & $746.47 * * *$ \\
5.1 cm vs. 7.6 cm & 1 & $28.60 *$ & $63.89 * *$ \\
N x Cutting management & 4 & 29.60 & 21.90 \\
Error a & 24 & 125.78 & 138.72 \\
& & & $1824.74 * * *$ \\
Harvest period & 2 & $512.25 * * *$ & $1675.37 * * *$ \\
Harvest period 1 vs. harvest periods 2 and 3 & 1 & $443.86 * * *$ & $149.37 * * *$ \\
Harvest period 2 vs. harvest period 3 & 1 & $68.39 * * *$ & 13.02 \\
N x Harvest period & 4 & 10.05 & $179.40^{* * *}$ \\
Cutting management x Harvest period & 4 & $226.24 * * *$ & $50.86 *$ \\
N x Cutting management x Harvest period & 8 & $51.23 *$ & 157.47 \\
Error b & 54 & 137.74 & \\
\hline
\end{tabular}

Note: Significance of $\mathrm{F}$ test. $*, \mathrm{P}<0.05 ; * *, \mathrm{P}<0.01 ; * * * \mathrm{P}<0.0001$. 
Analysis of variance for root volume at each sampling depth

\begin{tabular}{|c|c|c|c|c|c|c|}
\hline \multirow[b]{3}{*}{ Source } & \multicolumn{6}{|c|}{ Depth } \\
\hline & \multicolumn{2}{|c|}{$0.0-5.1 \mathrm{~cm}$} & \multicolumn{2}{|c|}{$5.1-10.2 \mathrm{~cm}$} & \multicolumn{2}{|c|}{$10.2-20.3 \mathrm{~cm}$} \\
\hline & df & $\begin{array}{c}\text { Analysis of } \\
\text { variance } \\
\text { partial sums } \\
\text { of squares } \\
\end{array}$ & df & $\begin{array}{c}\text { Analysis of } \\
\text { variance } \\
\text { partial sums } \\
\text { of squares } \\
\end{array}$ & df & $\begin{array}{c}\text { Analysis of } \\
\text { variance } \\
\text { partial sums } \\
\text { of squares } \\
\end{array}$ \\
\hline Block & 3 & $460.77^{*}$ & 3 & $67.62 *$ & 3 & $42.48 *$ \\
\hline Nitrogen & 2 & $410.49 * *$ & 2 & 9.12 & 2 & 8.69 \\
\hline none vs. medium and high & 1 & $338.59 * *$ & 1 & 8.91 & 1 & 5.11 \\
\hline medium vs. high & 1 & 71.89 & 1 & 0.21 & 1 & 3.63 \\
\hline Cutting management & 2 & $282.56^{*}$ & 2 & 0.60 & 2 & 5.64 \\
\hline $2.5 \mathrm{~cm}$ vs. 5.1 and $7.6 \mathrm{~cm}$ & 1 & $281.70 * *$ & 1 & 0.48 & 1 & 0.10 \\
\hline $5.1 \mathrm{~cm}$ vs. $7.6 \mathrm{~cm}$ & 1 & 0.86 & 1 & 0.12 & 1 & 5.54 \\
\hline Error a & 24 & 838.98 & 24 & 154.58 & 24 & 112.92 \\
\hline Date/Year & 6 & $1923.11 * * *$ & 6 & $259.4 * * *$ & 6 & $176.22 * * *$ \\
\hline April 15, 1999 vs. May 27, 1999 to October 13, 2000 & 1 & $225.64 *$ & 1 & 11.96 & 1 & $21.28 * *$ \\
\hline 1999 vs. 2000 & 1 & $958.87 * * *$ & 1 & 18.08 & 1 & 4.03 \\
\hline September 22, 1999 vs. May 27 and October 25, 1999 & 1 & 0.04 & 1 & 2.56 & 1 & $23.34 * *$ \\
\hline May 27, 1999 vs. October 25, 1999 & 1 & 24.50 & 1 & $38.28 * *$ & 1 & $70.01 * * *$ \\
\hline August 28, 2000 vs. May 30 and October 13, 2000 & 1 & 47.32 & 1 & 15.84 & 1 & $14.78^{*}$ \\
\hline May 30, 2000 vs. October 13, 2000 & 1 & $666.73 * * *$ & 1 & $172.67 * * *$ & 1 & $42.78 * *$ \\
\hline Nitrogen $x$ Date & 12 & 251.20 & 12 & 89.80 & 12 & 25.30 \\
\hline Cutting management $\mathrm{x}$ Date & 12 & $779.74 *$ & 12 & 63.11 & 12 & 39.81 \\
\hline Nitrogen x Cutting management $x$ Date & 24 & 742.89 & 24 & 83.69 & 24 & 77.72 \\
\hline Error b & 162 & 5736.55 & 162 & 812.36 & 161 & 460.44 \\
\hline
\end{tabular}

Note: Significance of F test. *, $\mathrm{P}<0.05 ; * *, \mathrm{P}<0.01 ; * * * \mathrm{P}<0.0001$. 
Analysis of variance for root dry weight at each sampling depth

\begin{tabular}{|c|c|c|c|c|c|c|}
\hline \multirow[b]{3}{*}{ Source } & \multicolumn{6}{|c|}{ Depth } \\
\hline & \multicolumn{2}{|c|}{$0.0-5.1 \mathrm{~cm}$} & \multicolumn{2}{|r|}{$5.1-10.2 \mathrm{~cm}$} & \multicolumn{2}{|c|}{$10.2-20.3 \mathrm{~cm}$} \\
\hline & df & $\begin{array}{c}\text { Analysis of } \\
\text { variance } \\
\text { partial sums } \\
\text { of squares } \\
\end{array}$ & df & $\begin{array}{c}\text { Analysis of } \\
\text { variance } \\
\text { partial sums } \\
\text { of squares } \\
\end{array}$ & df & $\begin{array}{c}\text { Analysis of } \\
\text { variance } \\
\text { partial sums } \\
\text { of squares } \\
\end{array}$ \\
\hline Block & 3 & $61.19 *$ & 3 & 3.83 & 3 & $4.61 *$ \\
\hline Nitrogen & 2 & $65.16 * *$ & 2 & 0.92 & 2 & 1.34 \\
\hline none vs. medium and high & 1 & $61.71 * *$ & 1 & 0.88 & 1 & 0.41 \\
\hline medium vs. high & 1 & 3.45 & 1 & 0.05 & 1 & 0.94 \\
\hline Cutting management & 2 & 26.34 & 2 & 0.25 & 2 & 1.08 \\
\hline $2.5 \mathrm{~cm}$ vs. 5.1 and $7.6 \mathrm{~cm}$ & 1 & $24.50 *$ & 1 & 0.05 & 1 & 0.31 \\
\hline $5.1 \mathrm{~cm}$ vs. $7.6 \mathrm{~cm}$ & 1 & 1.84 & 1 & 0.20 & 1 & 0.77 \\
\hline Error a & 24 & 108.88 & 24 & 11.71 & 24 & 9.99 \\
\hline Date/Year & 6 & $193.64 * * *$ & 6 & $19.29 * * *$ & 6 & $15.17 * * *$ \\
\hline April 15, 1999 vs. May 27, 1999 to October 13, 2000 & 1 & $86.25 * * *$ & 1 & 0.16 & 1 & 0.74 \\
\hline 1999 vs. 2000 & 1 & $36.82 * *$ & 1 & 1.06 & 1 & 0.03 \\
\hline September 22, 1999 vs. May 27 and October 25, 1999 & 1 & 6.81 & 1 & $1.68 *$ & 1 & $2.37 * *$ \\
\hline May 27, 1999 vs. October 25, 1999 & 1 & $21.76^{*}$ & 1 & $8.83 * * *$ & 1 & $11.00 * * *$ \\
\hline August 28, 2000 vs. May 30 and October 13, 2000 & 1 & 3.67 & 1 & $1.40 *$ & 1 & 0.18 \\
\hline May 30, 2000 vs. October 13, 2000 & 1 & $38.34 * *$ & 1 & $6.00 * * *$ & 1 & 0.69 \\
\hline Nitrogen x Date & 12 & 50.32 & 12 & 5.85 & 12 & 2.71 \\
\hline Cutting management x Date & 12 & 83.43 & 12 & 4.57 & 12 & 3.73 \\
\hline Nitrogen $x$ Cutting management $x$ Date & 24 & 66.15 & 24 & 6.61 & 24 & 7.24 \\
\hline Error b & 162 & 678.98 & 161 & 49.70 & 160 & 34.47 \\
\hline
\end{tabular}

Note: Significance of $\mathrm{F}$ test. $*, \mathrm{P}<0.05 ; * *, \mathrm{P}<0.01 ; * * * \mathrm{P}<0.0001$. 
Analysis of variance for root length at each sampling depth

\begin{tabular}{|c|c|c|c|c|}
\hline \multirow[b]{3}{*}{ Source } & \multicolumn{4}{|c|}{ Depth } \\
\hline & & $0.0-5.1 \mathrm{~cm}$ & $5.1-10.2 \mathrm{~cm}$ & $10.2-20.3 \mathrm{~cm}$ \\
\hline & df & \multicolumn{3}{|c|}{ Analysis of variance partial sums of squares } \\
\hline Block & 1 & $16718342.87 * *$ & $3786281.23 * *$ & $3007331.69 * *$ \\
\hline Nitrogen & 1 & 1318500.71 & 1700.06 & 55467.13 \\
\hline Cutting management & 1 & $3328996.37 *$ & 98355.23 & 66954.49 \\
\hline Error a & 3 & 911601.81 & 325500.43 & 98183.95 \\
\hline Date/Year & 6 & $30855694.35 * * *$ & $2403566.84 * *$ & $2416238.65^{* *}$ \\
\hline April 15, 1999 vs. May 27, 1999 to October 13, 2000 & 1 & 974643.02 & 207598.41 & $496971.66^{*}$ \\
\hline 1999 vs. 2000 & 1 & $12160040.07 * *$ & 69582.41 & 267998.22 \\
\hline September 22, 1999 vs. May 27 and October 25, 1999 & 1 & 1263969.71 & 60927.30 & 1794.75 \\
\hline May 27, 1999 vs. October 25, 1999 & 1 & 2139659.50 & 299219.94 & $458122.54^{*}$ \\
\hline August 28, 2000 vs. May 30 and October 13, 2000 & 1 & $5168526.58 * *$ & $595466.44 * *$ & $684517.83 * *$ \\
\hline May 30, 2000 vs. October 13, 2000 & 1 & $9148855.46 * *$ & $1170772.69 * *$ & $506833.65^{*}$ \\
\hline Nitrogen $x$ Date & 6 & 1565227.72 & 560133.31 & 879429.64 \\
\hline Cutting management $\mathrm{x}$ Date & 6 & 2742384.52 & 582218.75 & 975329.69 \\
\hline Nitrogen $x$ Cutting management $x$ Date & 6 & 960105.28 & 262711.82 & 109386.56 \\
\hline$\underline{\text { Error b }}$ & 24 & 15245233.72 & 2118012 & 2222797.49 \\
\hline
\end{tabular}

Note: Significance of F test. * ${ }^{*} \mathrm{P}<0.05$; **, $\mathrm{P}<0.01$; *** $\mathrm{P}<0.0001$. 


\section{Appendix Table K}

Analysis of variance for soil $\mathrm{NO}_{3}{ }^{-}$for 1999 and 2000

\begin{tabular}{|c|c|c|c|c|}
\hline \multirow[b]{2}{*}{ Source } & \multicolumn{2}{|r|}{1999} & \multicolumn{2}{|r|}{2000} \\
\hline & df & $\begin{array}{c}\text { Analysis of } \\
\text { variance partial } \\
\text { sums of squares }\end{array}$ & df & $\begin{array}{c}\text { Analysis of } \\
\text { variance partial } \\
\text { sums of squares }\end{array}$ \\
\hline Block & 3 & 0.09 & 3 & 1.10 \\
\hline Nitrogen & 2 & $2.93 *$ & 2 & $10.37 *$ \\
\hline none vs. medium and high & 1 & $2.13 *$ & 1 & $10.06^{*}$ \\
\hline medium vs high & 1 & 0.80 & 1 & 0.31 \\
\hline Cutting management & ----- & ----- & 2 & $11.63 *$ \\
\hline $2.5 \mathrm{~cm}$ vs. 5.1 and $7.6 \mathrm{~cm}$ & ----- & ----- & 1 & $11.41 * *$ \\
\hline $5.1 \mathrm{~cm}$ vs. $7.6 \mathrm{~cm}$ & ----- & ----- & 1 & 0.22 \\
\hline Nitrogen $\mathrm{x}$ Cutting management & ----- & ----- & 4 & 7.81 \\
\hline Error a & 6 & 1.37 & 24 & 34.82 \\
\hline Date & 1 & $1.56 * *$ & 1 & $26.22 * * *$ \\
\hline Nitrogen $x$ Date & 2 & 0.07 & 2 & 7.84 \\
\hline Cutting management $\mathrm{x}$ Date & ----- & ----- & 2 & 1.65 \\
\hline Nitrogen $x$ Cutting management $x$ Date & ----- & ----- & 4 & $20.58 * *$ \\
\hline Error b & 9 & 0.85 & 27 & 34.82 \\
\hline
\end{tabular}

Note: Significance of F test. * ${ }^{*} \mathrm{P}<0.05 ; * *, \mathrm{P}<0.01 ; * * * \mathrm{P}<0.0001$. 


\section{Appendix Table L}

Analysis of variance of soil pH and available soil P, K, Ca and Mg in experimental plots in 1999 and 2000

\begin{tabular}{|c|c|c|c|c|c|c|c|}
\hline \multirow{2}{*}{ Source } & \multirow[b]{2}{*}{ df } & pH & $\mathbf{P}$ & \multirow[b]{2}{*}{ df } & $\mathbf{K}$ & $\mathbf{C a}$ & Mg \\
\hline & & \multicolumn{2}{|c|}{$\begin{array}{l}\text { Analysis of variance of } \\
\text { partial sums of squares }\end{array}$} & & \multicolumn{3}{|c|}{ Analysis of variance of partial sums of squares } \\
\hline Block & 3 & $1.26^{* * *}$ & $2865.69 * * *$ & 3 & $78009.59 * * *$ & 5697669.62 & $11931.61 * * *$ \\
\hline $\mathrm{N}$ & 2 & 0.17 & 537.50 & 2 & 4173.06 & 2993296.99 & 1655.92 \\
\hline none vs. medium and high & 1 & 0.02 & 78.13 & 1 & 3512.15 & 2396915.66 & 27.21 \\
\hline medium vs. high & 1 & 0.16 & 459.38 & 1 & 610.48 & 637097.46 & 1635.34 \\
\hline Cutting Management & 2 & 0.05 & 237.04 & 2 & 973.22 & 640525.23 & 457.60 \\
\hline $2.5 \mathrm{~cm}$ vs. 5.1 and $7.6 \mathrm{~cm}$ & 1 & 0.05 & 236.53 & 1 & 61.53 & 499753.84 & 432.44 \\
\hline $5.1 \mathrm{~cm}$ vs. $7.6 \mathrm{~cm}$ & 1 & 0.00 & 0.51 & 1 & 907.64 & 145256.92 & 26.94 \\
\hline N x Cutting Management & 4 & 0.46 & 650.21 & 4 & 12303.07 & 4710441.54 & 2860.74 \\
\hline Error a & 24 & 1.63 & 3752.25 & 24 & 236255.10 & 36513635.28 & 23033.18 \\
\hline Year & 1 & $0.24 * *$ & $1501.56^{* * * *}$ & 1 & 3317.52 & $28377034.03 * * *$ & $26696.60 * * *$ \\
\hline N x Year & 2 & 0.01 & 8.17 & 2 & $12573.80 *$ & 774782.99 & 484.85 \\
\hline Cutting Management x Year & 2 & 0.03 & 60.79 & 2 & $29831.66 * *$ & 6134593.71 & 564.97 \\
\hline N x Cutting Management x Year & 4 & 0.14 & 161.29 & 4 & 2392.59 & 5234267.41 & 2590.16 \\
\hline Error b & 99 & 2.20 & 5072.44 & 95 & 165772.26 & 118709883.52 & 41531.91 \\
\hline
\end{tabular}

Note: Significance of $\mathrm{F}$ test. ${ }^{*}, \mathrm{P}<0.05 ; * *, \mathrm{P}<0.01 ; * * * \mathrm{P}<0.0001$. 


\section{VITA}

Name ...................... Gina Marie Kertulis

Parents . . . . . . . . . . . . . Mr. Anthony Steve Kertulis, Sr.

Mrs. Barbara Ellen (Humer) Kertulis

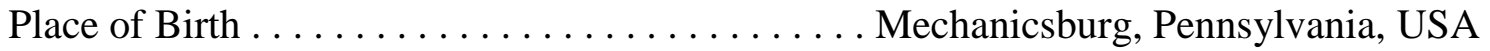

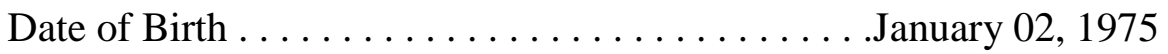

Schools Attended:

West Creek Hills Elementary School . . . . . . . . . . . . . . . . 1980 - 1986

East Pennsboro Area Middle School . . . . . . . . . . . . . . . . . . . . 1986 - 1989

East Pennsboro Area High School . . . . . . . . . . . . . . . . . . . 1989 - 1993

Harrisburg Area Community College (HACC) . . . . . . . . . . . . . 1993 - 1995

The Pennsylvania State University (PSU) . . . . . . . . . . . . . . 1995 - 1998

West Virginia University (WVU). . . . . . . . . . . . . . . . . . 1998 - 2001

Degrees Received:

BS, Soil Science, The Pennsylvania State University, 1998

BS, Agronomy, The Pennsylvania State University, 1998 